Invited Review

\title{
Measuring, modelling and managing gully erosion at large scales: A state of the art
}

\author{
Matthias Vanmaercke ${ }^{\text {a,b, }}$, Panos Panagos ${ }^{c}$, Tom Vanwalleghem $^{\mathrm{d}}$, Antonio Hayas ${ }^{\mathrm{e}}$, \\ Saskia Foerster ${ }^{\mathrm{f}}$, Pasquale Borrelli ${ }^{\mathrm{g}}{ }^{\mathrm{h}}$, Mauro Rossi ${ }^{\mathrm{i}}$, Dino Torri $^{\mathrm{i}}{ }^{\mathrm{i}}$ Javier Casali $^{\mathrm{j}}$, \\ Lorenzo Borselli $^{k}$, Olga Vigiak ${ }^{\mathrm{c}}$, Michael Maerker ${ }^{1}$, Nigussie Haregeweyn ${ }^{\mathrm{m}}$, Sofie De Geeter ${ }^{\mathrm{a}, \mathrm{b}}$,

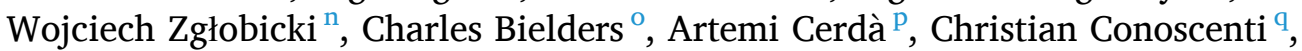 \\ Tomás de Figueiredo ${ }^{\mathrm{r}}$, Bob Evans ${ }^{\mathrm{s}}$, Valentin Golosov ${ }^{\mathrm{t}, \mathrm{u}}$, Ion Ionita ${ }^{\mathrm{v}}$, Christos Karydas ${ }^{\mathrm{w}}$, \\ Adam Kertész $^{\mathrm{x}, \mathrm{y}}$, Josef Krása ${ }^{\mathrm{z}}$, Caroline Le Bouteiller ${ }^{\mathrm{aa}}$, Maria Radoane ${ }^{\mathrm{ab}}$, Ratko Ristić ${ }^{\mathrm{ac}}$, \\ Svetla Rousseva ${ }^{\text {ad }}$, Milos Stankoviansky ${ }^{\text {ae }}$, Jannes Stolte ${ }^{\text {af }}$, Christian Stolz ${ }^{\text {ag }}$, Rebecca Bartley ${ }^{\text {ah }}$, \\ Scott Wilkinson ${ }^{\text {ai }}$, Ben Jarihani ${ }^{\text {aj, ak }}$, Jean Poesen ${ }^{\text {b, n }}$
}

${ }^{\text {a }}$ University of Liege, Department of Geography (U.R. SPHERES), Clos Mercator 3, 4000 Liège, Belgium

${ }^{\mathrm{b}}$ KU Leuven, Department of Earth and Environmental Sciences, Celestijnenlaan 200E, 3001 Heverlee, Belgium

${ }^{\mathrm{c}}$ European Commission Joint Research Centre (JRC), Ispra (VA), Italy

d University of Córdoba, Department of Agronomy, Ctra. Nacional IV km.396, 14071 Córdoba, Spain

e University of Córdoba, Department of Rural Engineering, Ctra. Nacional IV km.396, 14071 Córdoba, Spain

f GFZ German Research Centre for Geosciences, Section Remote Sensing and Geoinformatics, Telegrafenberg, 14473 Potsdam, Germany

${ }^{g}$ University of Pavia, Department of Earth and Environmental Sciences, Via Ferrata, 1, 27100 Pavia, Italy.

${ }^{\mathrm{h}}$ Kangwon National University, Department of Biological Environment, Chuncheon 24341, Republic of Korea

${ }^{\mathrm{i}}$ Istituto di Ricerca per la Protezione Idrogeologica, Consiglio Nazionale Delle Ricerche, Via della Madonna Alta 126, 06128 Perugia, Italy

${ }^{\mathrm{j}}$ Public University of Navarre, Department of Engineering, IS-FOOD Institute (Innovation \& Sustainable Development in Food Chain), Campus de Arrosadía, 31006

Pamplona, Navarre, Spain

${ }^{\mathrm{k}}$ Universidad Autónoma de San Luis Potosí, Institute of Geology, Av. Dr. Manuel Nava 5, 78240 San Luis Potosí, Mexico

${ }^{1}$ Università degli Studi di Pavia, Department of Earth and Environmental Sciences, Via Ferrata 1, 27100 Pavia, Italy

${ }^{\mathrm{m}}$ International Platform for Dryland Research and Education, Tottori University, Tottori 680-0001, Japan

${ }^{\mathrm{n}}$ Maria-Curie Sklodowska University, Faculty of Earth Sciences and Spatial Management, Krasnicka 2D, 20-718 Lublin, Poland

${ }^{\circ}$ Earth and Life Institute - Environmental Sciences, Université catholique de Louvain, Croix du sud 2, L7.05.02, 1348 Louvain-la-Neuve, Belgium

${ }^{\mathrm{p}}$ Soil Erosion and Degradation Research Group, Department of Geography, Valencia University, Blasco Ibànez, 28, 46010, Valencia, Spain

${ }^{\mathrm{q}}$ University of Palermo, Department of Earth and Marine Sciences, Via Archirafi 22, 90123 Palermo, Italy

${ }^{\mathrm{r}}$ Mountain Research Centre (CIMO), Instituto Politécnico de Bragança, Campus de Santa Apolónia, 5300-253 Bragança, Portugal

${ }^{\mathrm{s}}$ Anglia Ruskin University, Global Sustainability Institute, East Road, Cambridge CB1 IPT, United Kingdom

${ }^{\mathrm{t}}$ Lomonosov Moscow State University, Faculty of Geography, Leninskie Gory 1, 119991 Moscow, Russia

${ }^{\mathrm{u}}$ Russian Academy of Science, Institute of Geography, Staromonetniy Lane, 29, 119017 Moscow, Russia

${ }^{v}$ Alexandru Ioan Cuza University, Department of Geography, Carol I Blvd. 24, 700505 Iași, Romania

${ }^{\mathrm{w}}$ Remote Sensing Engineer, Mesimeri P.O. Box 413, 57500 Epanomi, Greece

${ }^{\mathrm{x}}$ Research Center for Astronomy and Earth Sciences, Geographical Institute, H-1112 Budapest, Budaörsi út 45, Hungary

${ }^{\text {y }}$ Eszterházy Károly University, Institute of Geography and Environmental Sciences, H.3300 Eger, Eszterházy tér 1, Hungary

${ }^{\mathrm{z}}$ CTU In Prague, Department of Landscape Water Conservation, Faculty of Civil Engineering, Thakurova 7, 16629 Prague 6, Czech Republic

${ }^{\text {aa }}$ Université Grenoble Alpes, INRAE UR ETNA, 38400 Saint Martin d'Heres, France

${ }^{\mathrm{ab}}$ Stefan cel Mare University, Department of Geography, Universității,13, 720229 Suceava, Romania

${ }^{\text {ac }}$ University of Belgrade, Faculty of Forestry, Kneza Višeslava 1, 11030 Belgrade, Serbia

${ }^{a d}$ Nikola Poushkarov Institute of Soil Science, Agrotechnologies and Plant Protection, Department of Soil Physics, Erosion and Biota, Shosse Bankya Str. 7, 1331 Sofia, Bulgaria

ae Comenius University in Bratislava, Faculty of Natural Sciences, Department of Physical Geography and Geoecology, Mlynská Dolina, Ilkovičova 6, 842 15 Bratislava 4, Slovakia

${ }_{\text {af }}$ Norwegian Institute of Bioeconomy Research (NIBIO), Ås, Norway

${ }^{\mathrm{ag}}$ Europe University of Flensburg, Department of Biology and its Didactics (Physical Geography), Auf dem Campus 1, 24943 Flensburg, Germany

ah CSIRO Land and Water, Ecosciences Precinct, Brisbane, Queensland, Australia

ai CSIRO Land and Water, Clunies Ross Street, Black Mountain, 2601 Canberra, Australia

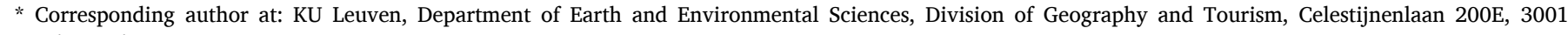
Heverlee, Belgium.
}

https://doi.org/10.1016/j.earscirev.2021.103637 
aj University of Central Asia, Mountain Societies Research Institute, Khorog, Tajikistan

${ }^{\mathrm{ak}}$ University of the Sunshine Coast, Sustainability Research Centre, 90 Sippy Downs Drive, Australia

\section{A R T I C L E I N F O}

\section{Keywords:}

Gully erosion

Gully initiation

Gully expansion

Sediment yield

Measuring

Modelling

Prediction

Regional

Continental

Europe

Spatial data

Policy

\begin{abstract}
A B S T R A C T
Soil erosion is generally recognized as the dominant process of land degradation. The formation and expansion of gullies is often a highly significant process of soil erosion. However, our ability to assess and simulate gully erosion and its impacts remains very limited. This is especially so at regional to continental scales. As a result, gullying is often overlooked in policies and land and catchment management strategies. Nevertheless, significant progress has been made over the past decades. Based on a review of $>590$ scientific articles and policy documents, we provide a state-of-the-art on our ability to monitor, model and manage gully erosion at regional to continental scales. In this review we discuss the relevance and need of assessing gully erosion at regional to continental scales (Section 1); current methods to monitor gully erosion as well as pitfalls and opportunities to apply them at larger scales (section 2); field-based gully erosion research conducted in Europe and European Russia (section 3); model approaches to simulate gully erosion and its contribution to catchment sediment yields at large scales (section 4); data products that can be used for such simulations (section 5); and currently existing policy tools and needs to address the problem of gully erosion (section 6). Section 7 formulates a series of recommendations for further research and policy development, based on this review. While several of these sections have a strong focus on Europe, most of our findings and recommendations are of global significance.
\end{abstract}

\section{Introduction}

\subsection{The relevance of gully erosion}

Soil erosion is globally recognized as the most dominant process of land degradation (e.g. Montanarella et al., 2016; Pennock, 2019). Most efforts to understand and quantify soil erosion by water have focussed on sheet and rill erosion (e.g. Renard, 1997; Montgomery, 2007; Maetens et al., 2012a; de Vente et al., 2013; Borrelli et al., 2017a). Nonetheless, numerous studies have highlighted the fact that also gully erosion is a key concern in many regions worldwide (Poesen et al., 2003; Valentin et al., 2005; Vanmaercke et al., 2011; García-Ruiz et al., 2017; Sidle et al., 2019). Overall, gully erosion is the formation and subsequent expansion of erosional channels in the soil as a result of concentrated water flow (Poesen et al., 2003). Gully dimensions can vary over several orders of magnitudes (e.g. Vanmaercke et al., 2016; Dube et al., 2020). However, conventionally a gully is distinguished from a rill based on a critical cross-sectional area of at least one square foot, i.e. the size of a channel that can no longer be erased via normal tillage operations (Poesen et al., 2003). An upper limit for gully dimensions has not been clearly defined yet.

Gullies are often associated with a wide range of on-site and off-site impacts. On-site impacts include the direct loss of land, trees and crops as well as reduced trafficability. These limit opportunities for agriculture and other land uses (e.g. Poesen et al., 2003; Valentin et al., 2005). Gullies can also cause significant damage to roads, buildings and other infrastructure. In severe cases, such destructions may claim significant numbers of casualties (e.g. Guerra et al., 2007; Makanzu Imwangana et al., 2015). In many regions, gully erosion contributes to significant soil losses and reduced soil quality (Poesen et al., 1996, 2003; Ionita, 2006; Haregeweyn et al., 2008; Xu et al., 2016; Hayas et al., 2017a), threatening the long-term sustainability of food production and other ecosystem services (e.g. Montgomery, 2007). Gullies can also significantly alter surface and subsurface hillslope hydrology. For example, their presence can lead to a more efficient water evacuation and, in some cases, lower water tables. In dry environments, this can result in significantly lower crop yields in areas bordering gullies (e.g. Frankl et al., 2016; Poesen, 2018) and reduced biomass production rates over larger spatial scales (e.g. Avni, 2005), contributing to desertification. In addition, gullies can initiate or aggravate other erosion processes, including soil piping (Bernatak-Jakiel \& Poesen, 2018) and landsliding (e.g. Ionita et al., 2015a). As a result of such impacts, gully erosion can also become a significant driver of land use changes (e.g. Bakker et al., 2005; Valentin et al., 2005; Zgłobicki et al., 2015a). In extreme cases, gully erosion can even transform productive land into badland areas (Cánovas et al., 2017; Torri et al., 2018a).

Potential off-site impacts of gully erosion include changes in catchment hydrology, such as lower river baseflows and higher peak runoff discharges (e.g. Martineli Costa and Bacellar, 2007). Given their often high erosion rates, gullies can also be a major sediment source. Where they occur, gullies can easily account for $20-80 \%$ of the average catchment sediment yield (e.g. Poesen et al., 1996, 2003; Vanmaercke et al., 2012). Furthermore, gullies can indirectly contribute to sediment loads by increasing the runoff and sediment connectivity between upland areas, valley bottoms and river networks or lakes (Poesen et al., 2003). These higher sediment loads and increased connectivity can result in a plethora of problems, including (muddy) floods (e.g. Verstraeten and Poesen, 1999), reservoir capacity losses due to sediment deposition (e.g. Haregeweyn et al., 2006), channel aggradation (e.g. Benda et al., 2003) and reduced water quality (e.g. Owens et al., 2005). As such, gully erosion is a great concern in many regions worldwide (Valentin et al., 2005; Poesen, 2018). It is a key process of land degradation and desertification (Vanmaercke et al., 2011), posing a significant threat to various ecosystems and ecosystem services (e.g. Kroon et al., 2012, 2016).

Given these impacts and concerns, land use and catchment management strategies are needed that allow the prevention and mitigation of gully erosion and its impacts (e.g. Poesen et al., 2003; Poesen, 2018). Nevertheless, controlling gully erosion is often complex and costly and typically requires a catchment-wide approach (Golosov and Belyaev, 2013). Conventional erosion control measures aimed at reducing sheet and rill erosion on hillslopes are often insufficient and specific interventions, such as the installation of check dams or revegetation within the gully channel, are often required. Successfully implementing such measures is usually very challenging, due to their risk of failure, their need for maintenance, feedback mechanisms like the 'clear water' effect, but also their often high associated costs (e.g. Stokes et al., 2014; Frankl et al., 2016; Ayele et al., 2018; Lucas-Borja et al., 2018; Rey et al., 2019; Bartley et al., 2020; Frankl et al., 2021).

Nevertheless, it is worth noting that gullies can sometimes also create interesting opportunities and positive outcomes. When well managed, they can become productive and biodiverse hotspots that play a key role as ecological corridors (Romero-Díaz et al., 2019). Likewise, gully channels can become significant sediment traps and fill-up over time, especially when they are well vegetated (e.g. Vanwalleghem et al., 2005c; Lanckriet et al., 2015; Molina et al., 2009). Furthermore, they can be of significant geo-archeological value, providing important insight into (pre-)historic land use and human occupation (e.g. 
Dotterweich, 2003; Dotterweich et al., 2003, 2012; Vanwalleghem et al., 2003; Torri et al., 2018a; Maerker et al., 2019). As such, they are generally seen by the scientific community as a key landform to understand the environmental change and soil erosion risks and they can play an important role in raising general awareness about these issues (e. g. Poesen et al., 2003; Frankl et al., 2011; Zgłobicki et al., 2015b; Zglobicki et al., 2019). Given their great visibility they can also help in raising awareness on erosion problems (e.g. Bielders et al., 2003; Zegeye et al., 2010). Because of their often great esthetical value or spectacular nature, several gullied areas and badlands even have large potential as geoheritage sites (Zgłobicki et al., 2018).

\subsection{The challenge of assessing gully erosion at regional to continental} scales

Developing appropriate gully erosion prevention and remediation strategies requires a thorough understanding of its dynamics and controlling factors. Gully erosion has already received a lot of research attention over the past century (Castillo and Gómez, 2016). This led to valuable insights on the formation and expansion of gullies, their contribution to sediment loads and their potential remediation. This research also demonstrated the sensitivity of gully erosion to land use/ land cover (e.g. Prosser and Slade, 1994; Poesen et al., 2003; Torri and Poesen, 2014) and rainfall intensity (e.g. Vanmaercke et al., 2016; Hayas et al., 2017b). Globally ongoing land use/land cover changes that have a significant effect on sheet and rill erosion (Borrelli et al., 2017a) therefore probably also strongly impact gully erosion rates. Likewise, climate change and in particular increases in rainfall intensities (e.g. Polade et al., 2014) are likely to further intensify gully erosion rates (e.g. Nearing et al., 2004; Li and Fang, 2016; Vanmaercke et al., 2016; Panagos et al., 2017). In order to address these challenges, there is a need for tools and models that can quantify the current rates and impacts of gully erosion and assess the effect of potential climate and land use change scenarios (e.g. Poesen, 2018; Pennock, 2019). However, our ability to simulate gully erosion and its impacts remains currently limited (Jetten et al., 2003; Merritt et al., 2003; Poesen et al., 2011; Vanmaercke et al., 2016; Bennett and Wells, 2019; Sidle et al., 2019), particularly at regional to continental scales (e.g. de Vente et al., 2013; Poesen, 2018). Insights at these scales are essential for the development of adequate and targeted land and catchment management strategies.

These difficulties to simulate and quantify gully erosion at regional to continental scales arise from several causes. First, there is a wide variety of gully types and sizes (Fig. 1). Examples include ephemeral gullies in cropland (e.g. Valcárcel et al., 2003), (pre-)historic gullies under forest (e.g. Dotterweich et al., 2003; Vanwalleghem et al., 2003), permanent gullies in rangeland (e.g. Gomez-Gutiérrez et al., 2009a), valley bottom gullies in alluvial planes (e.g. Amare et al., 2019), bank gullies (i.e. gullies forming in earth banks such as river banks, agricultural terraces, lynchets or sunken lane banks; e.g. Vandekerckhove et al., 2000a; Poesen et al., 2003), large gullies in urban environments (e.g. Guerra et al., 2007; Makanzu Imwangana et al., 2015), sunken lanes (or road gullies; e.g. De Geeter et al., 2020) and gullies in badland areas (e.g. Nadal-Romero et al., 2015). Furthermore, the formation and expansion of gullies typically involve a range of subprocesses, including the initial incision of a flow channel by concentrated runoff and the formation of a gully headcut (e.g. Oostwoud Wijdenes et al., 1999), gully headcut retreat (Vanmaercke et al., 2016), gully widening and deepening (e.g. Hayas et al., 2019), mass movements (e.g. Zegeye et al., 2020), fluting (Poesen et al., 2002), piping or tunnel erosion (Bernatak-Jakiel and Poesen, 2018), sediment transport and sediment deposition (e.g. Vanwalleghem et al., 2005c). The relative importance of these subprocesses depends on the type of gully, its environmental conditions, but also on the age of the gully (e.g. Oostwoud Wijdenes et al., 1999; Sidorchuk et al., 2001; Poesen et al., 2006; Sidorchuk, 2006; Frankl et al., 2021). In addition, and as a result of these complexities, gully erosion is also characterized by an important degree of stochasticity (e.g. Montgomery and Dietrich, 1994; Prosser and Abernethy, 1996). While significant advancements have been made over the past decades, our understanding of these processes, their interactions and their numerous potential controlling factors remains limited (Poesen et al., 2011; de Vente et al., 2013; Vanmaercke et al., 2016).

From the aforementioned points it also becomes clear that the simulation of gully erosion at larger scales requires significant amounts of data. These include input data on relevant environmental controlling factors (i.e. topography, soil characteristics, climate/weather conditions and land use/cover/management) but also observations on gully occurrence, dimensions and erosion rates to calibrate and validate models. Although several studies have attempted to model gully erosion at local scales, applying these models over larger areas is mostly impossible due to data constraints (e.g. Poesen et al., 2011; de Vente et al., 2013; Poesen, 2018). Furthermore, the environmental factors that need to be considered can vary depending on the study area and gully type. For example, valley bottom gullies are often linked to the presence of dispersive soils or specific conditions in subsurface hydrology (Imeson and Kwaad, 1980; Brooks et al., 2009; Amare et al., 2019). In other areas, seismic/tectonic activity seems to exert an important control on gully erosion (e.g. Cox et al., 2010; Marden et al., 2018). Also farming practices like tillage or parcellation patterns can play a key role in the formation of gullies (Poesen et al., 1996; Gordon et al., 2008; Zgłobicki and Baran-Zgłobicka, 2011). This large variation of controlling factors, subprocesses and their interactions further hampers the development and application of (process-based) gully erosion models at regional to continental scales. Finally, given its threshold-dependent nature, gully erosion is typically a highly erratic process, characterized by a very large temporal variability (e.g. Vandekerckhove et al., 2001b; Vanmaercke et al., 2016; Hayas et al., 2017b). Hence, identifying and constraining the key factors controlling gully erosion requires data on gully dynamics, land use, land management and weather conditions that are sufficiently detailed over long periods.

\subsection{Scope and overview of this review}

The previous subsections reveal that there is an important need for tools and models that allow quantifying and predicting gully erosion at regional (e.g. $>10,000 \mathrm{~km}^{2}$ ), continental and even global scales. Presently, no approaches can do this. However, important advancements have been made in this regard. These include a better understanding of gully erosion processes, novel model approaches and mapping techniques and the development of new high-resolution datasets. The objective of this review is to provide a state of the art of our ability to monitor, model and manage gully erosion at regional to continental scales. From this we aim to identify key research and policy gaps, but also opportunities and pathways to address this problem. The main focus area of this paper is Europe. However, the scope and relevance of this paper extent to other continents as well.

Section 2 reviews remote-sensing and field approaches to measure and monitor gully properties and their dynamics. We discuss the limitations and potential of these methods with a focus on their application over larger areas. Section 3 provides an overview of past field-based gully-erosion research in Europe and European Russia. This to provide an overview of available data and observations that may be useful for further model development, but also to identify current research focuses and knowledge gaps. In Section 4, we discuss modelling approaches used to simulate various relevant aspects of gully erosion (gully occurrence, gully expansion and the contribution of gullies to catchment sediment yields). Also here, our focus lies on the applicability of these approaches at regional to continental scales. Section 5 complements this objective by providing an overview of currently available GIS datasets that may be used as input for such models. We concentrate on datasets that are available for Europe or have a global coverage. Section 6 discusses to what extent environmental management policies and frameworks already account for the challenges posed by gully erosion (with a 
(a)
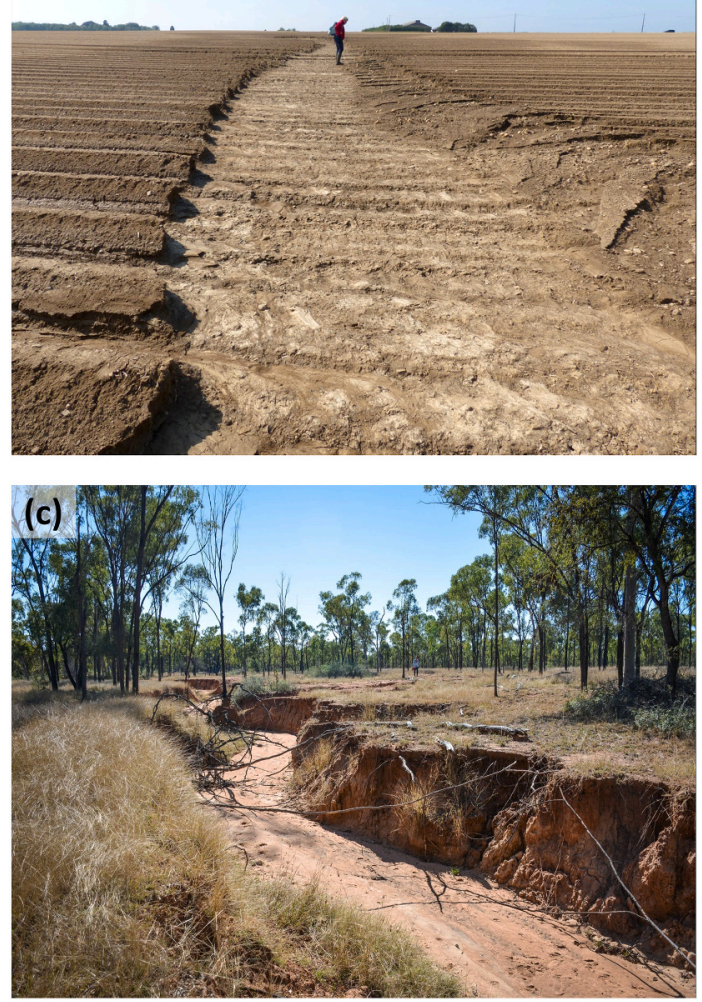

(e)
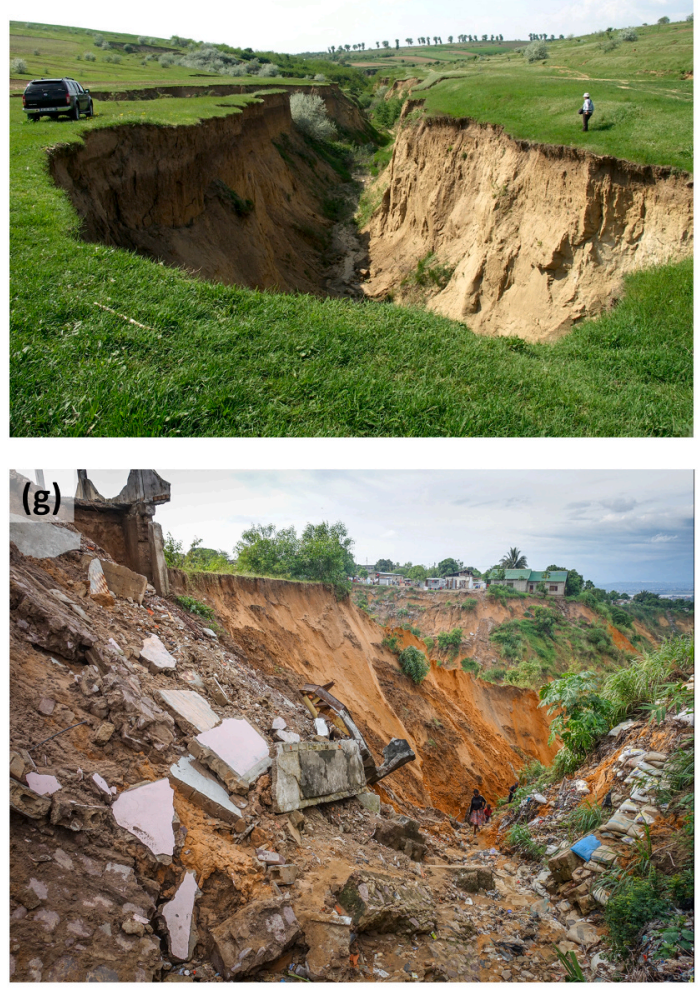
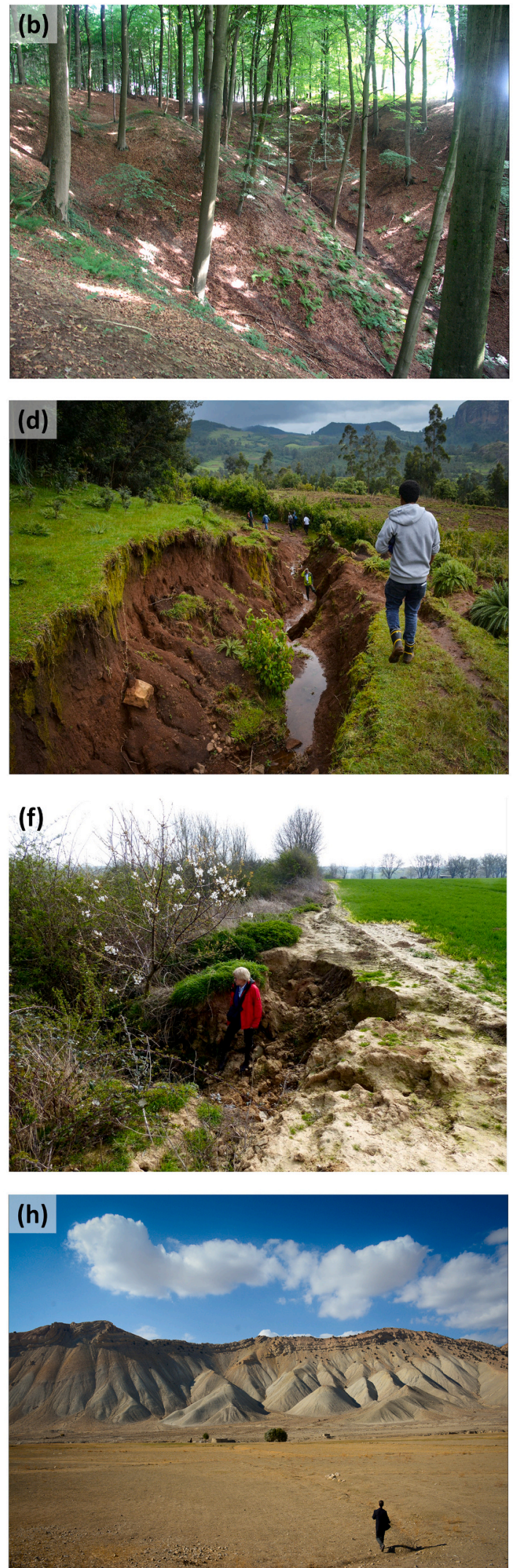

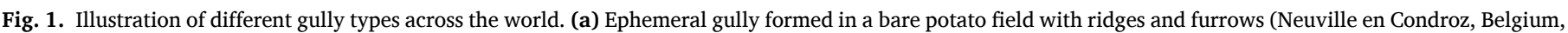

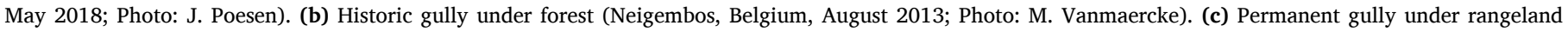

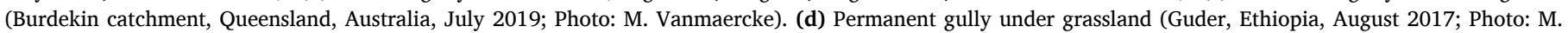

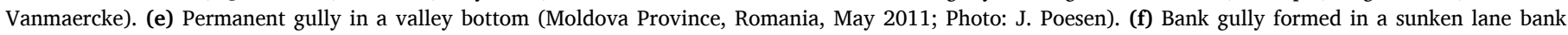

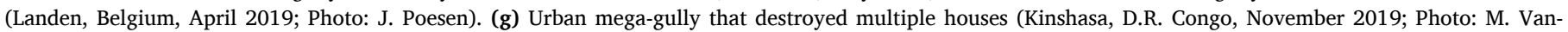
maercke). (h) Gullies formed in a badland area (near Quazvin, Iran, October 2014; Photo: M. Vanmaercke). 
focus on Europe). Section 7 synthesizes our key findings into a list of key recommendations with respect to the monitoring, modelling and managing of gully erosion at larger scales.

\section{Assessing gully erosion through monitoring}

Observations on the occurrence of gullies, their dimensions and their dynamics are essential to quantify gully erosion rates, to identify the factors that control them and to develop and evaluate predictive models (cf. Section 4). In addition, such measurements are indispensable to assess the effectiveness of gully control measures (e.g. Frankl et al., 2013, 2021; Bartley et al., 2020). Here we review and discuss different methods to monitor the presence gullies (cf. Section 2.1), their properties (cf. Section 2.2) and their dynamics (cf. Section 2.3), in particular at regional to continental scales.

\subsection{Assessing the presence or absence of gullies}

Especially at larger scales, time and labour constraints often limit the accuracy and level of detail of gully inventories. Nonetheless, inventories that simply record the 'presence' or 'absence' of gullies rather than their precise outlines can already greatly help in identifying problem areas and guiding policy decisions. Such approach has been followed in various regions, including Portugal (Vandaele et al., 1997), Belgium (Nachtergaele and Poesen, 1999), Ethiopia (Frankl et al., 2011), the USA (e.g. Bernard et al., 2010), Spain (e.g. Selkimäki and González-Olabarria, 2017), the European Union (Orgiazzi et al., 2018) and Australia (e.g. Hughes and Prosser, 2012; Darr and Pringle, 2017). This presence or absence can be assessed based on field surveys, aerial/ satellite photo interpretation and/or remote sensing analyses. For the latter, the presence of vegetation or snow can hamper successful detection (e.g. Marzolff and Poesen, 2009). Likewise, given that gullies can disappear or fill in over time, such inventories can be strongly timedependent. This is especially a concern for ephemeral gullies, which are often filled in by ploughing shortly after the rain event that triggered them. Assessments based on infrequent surveys can thus severely underestimate the occurrence of ephemeral gullies (e.g. Nachtergaele and Poesen, 1999), and lead to high levels of error (Kuhnert et al., 2010). Furthermore, such inventories strongly depend on the size of the spatial units in which the presence or absence of gullies is recorded (e.g. parcels, catchments, grids of fixed dimensions).

Creating detailed inventories of gully presence at high resolution can be very labour-intensive (e.g. one person-month for a $3000 \mathrm{~km}^{2}$ area at a 100 m pixel resolution; Darr and Pringle, 2017). Zhao et al. (2016) employed an alternative approach to estimate gully densities. Rather than systematically mapping entire areas, they assessed for a large number of random points whether or not the point was located inside a gully. The fraction of points located within a gully thus provides an estimate of the areal gully density. Such crude but fast proxy can be used for meaningful empirical analyses, e.g. to explore correlations between gully densities and catchment sediment yields (Zhao et al., 2016). Overall, complete assessments or random sampling procedures provide the advantage that mapping efforts are unbiased. In contrast, many existing gully occurrence studies focus on gully-prone areas and are therefore often unrepresentative at regional to continental scales.

A specific type of gully presence/absence inventories are maps that indicate the position of individual gully heads (e.g. Vandekerckhove et al., 1998, 2000b; Torri and Poesen, 2014; Hayas et al., 2017b). Since gully initiation and expansion are strongly controlled by local topographic and environmental conditions, such inventories are very useful for modelling purposes (cf. Section 4). However, since their construction is often labour-intensive, they typically remains limited to local study areas (Torri and Poesen, 2014). Nevertheless, the growing availability of high-resolution remote sensing imagery and digital elevation models (cf. Section 5) in combination with the development of (semi-) automatic gully detection procedures will likely increase the availability of such inventories at regional to continental scales.

\subsection{Assessing gully properties}

For some regions, more detailed inventories of gullies and their characteristics are available over large areas. An overview of such inventories for Europe is given in Section 3. Examples outside Europe include parts of Queensland (Australia; e.g. Brooks et al., 2009) and South Africa (e.g. Mararakanye and Le Roux, 2012). Most of these inventories represent gullies as either linear features (e.g. Rysin et al., 2017a; Rysin et al., 2017b) or as polygons (e.g. Saxton et al., 2012; Shellberg et al., 2016). They are mostly constructed by manually mapping gully extent from (historical) monoscopic/stereoscopic aerial photographs (e.g. Knight et al., 2007). More recent examples made use of high resolution DEMs and/or high resolution remote sensing images in combination with classification procedures that are increasingly automated, accurate and computationally efficient (e.g. Thommeret et al., 2010; Castillo et al., 2014a; Shruthi et al., 2014; Fiorucci et al., 2015; Shahabi et al., 2019; Walker et al., 2020). Evidently, such gully inventories allow for more detailed analyses. Characteristics like gullyhead locations (cf. Section 2.1) may be extracted from them relatively easily (e.g. Hayas et al., 2017b). They also allow more precise assessments of the areal and/or linear gully density.

However, such inventories also come with limitations. Digitizing gullies from aerial photos or remote sensing products often involves significant uncertainties. For example, Maugnard et al. (2014a) showed that mapping features of ephemeral gullies remains to a large extent subjective. Furthermore, their construction is generally very labourintensive, resulting in important trade-offs between the size of the study area, the level of detail and the labour investment required (e.g. Mararakanye and Le Roux, 2012; Golosov et al., 2018). Key elements in this are the image resolution and/or the mapping altitude (i.e. the difference between the altitude of the camera and the surface elevation) used but also whether gullies are mapped as linear features or polygons. (Semi-)automatic detection procedures offer promising perspectives here. They are typically based on high-resolution multi-spectral images (e.g. Shruthi et al., 2011) and/or high-resolution digital elevation models (e.g. Thommeret et al., 2010; Shahabi et al., 2019; Walker et al., 2020). Such imagery has become increasingly available at regional to continental scales. Nonetheless, most of the current applications remain limited to relatively small scales. The potential of these techniques needs to be further explored. Another promising option may be to optimize sampling protocols to manually inventorize gullies. This can be done, by stratifying areas in terms of ancillary information such as slope, land use or soil type (e.g. Minasny and McBratney, 2006) or by using a (semi-) random sampling procedure of smaller sites to be mapped (e.g. Vanmaercke et al., 2020).

Also the widths, cross-sectional areas and, by extent, the total gully volumes are often of interest. Gully top-widths can typically be derived from aerial or satellite imagery (e.g. Nachtergaele et al., 2002a; Hayas et al., 2017a). However, gully floor-widths are typically hard to measure from such imagery (Giménez et al., 2009). The top-widths may be significantly larger than the gully floor-widths, especially for older gullies or gullies formed in soils with little cohesion (e.g. Hayas et al., 2019). Nonetheless, gully floor-width and hydraulic radius are often of greater geomorphic relevance as they relate more directly to the maximum runoff discharges passing through the gully (e.g. Nachtergaele et al., 2002a; Vanwalleghem et al., 2005b).

Also gully cross-sectional areas are difficult to quantify based on aerial photos or high resolution satellite images. Nonetheless, they are a key prerequisite to estimate the volumes of gully systems (Casalí et al., 2015; Castillo et al., 2019). Therefore they are often obtained through field measurements (e.g. Nachtergaele et al., 2001a, 2001b). An uncertainty assessment by Castillo et al. (2012) showed that errors on individually measured cross-sections are overall relatively limited (3-15\%). Extrapolating these cross-sectional areas to estimate gully 
volumes typically generates larger uncertainties. These depend on the gully length, its sinuosity and in particular the number of cross-sections surveyed. Quantifying gully volumes with an acceptable degree of uncertainty (10-20\%) typically requires ten or more cross-sections per gully (Castillo et al., 2012). This can pose challenges when aiming to quantify gully erosion volumes over larger areas. Fortunately, gully cross-sectional areas are typically strongly correlated to their top-width (e.g. Frankl et al., 2013; Vanmaercke et al., 2016), which can be assessed via remote sensing. It is often feasible to develop robust empirical relationships between gully top-width and cross-sectional areas, based on a relatively limited amount of field surveys. These relationships can then be used to estimate gully volumes with acceptable uncertainties (e.g. Fiorucci et al., 2015; Hayas et al., 2017a). One concern with this approach is that the cross-sectional shapes evolve over time, e.g. from a rectangular to a more trapezoidal shape (e.g. Vanwalleghem et al., 2005b; Hayas et al., 2019). Hence, applying such a (time-specific) relationship to assess gully volumes over longer time periods may induce further uncertainties and biases.

The challenge to estimate gully volumes from 2D imagery is partly rendered obsolete by new techniques. Airborne LIDAR instruments, for example, allow mapping the morphology and volume of gully systems (e.g. James et al., 2007; Eustace et al., 2009; Perroy et al., 2010; Goodwin et al., 2017). The method, albeit expensive (Castillo et al., 2012), is relatively fast and typically allows to construct digital terrain models of gully systems with an accuracy of some centimeters to decimeters. Recently developed Structure from Motion (SfM) techniques offer a promising and cheaper alternative, with accuracies and precisions that are similar to LIDAR or in some cases even superior (e.g. Castillo et al., 2012; Gómez-Gutiérrez et al., 2014; Clapuyt et al., 2016; Koci et al., 2017). The photographic surveys required to construct a SfMbased digital terrain model can be conducted either from the ground or through drone flights. They can be made with standard photo cameras, while freely available software exists to process the photos into a 3D model (e.g. Koci et al., 2017). Nonetheless, vegetation cover can form a significant constraint for assessing gully properties via SfM. Also, as with LIDAR, data acquisition typically is labour-intensive and the computer resources required to construct such a 3D model currently remain considerable. Hence, most studies applying LIDAR or SfM to characterize gully systems cover only limited areas (e.g. Eustace et al., 2009; Perroy et al., 2010; Castillo et al., 2012; Kropacek et al., 2016; Koci et al., 2017). Increases in computational power and more efficient algorithms may make it feasible to apply these techniques at regional to continental scales in the near future (Bennett and Wells, 2019).

Apart from assessing gully dimensions, assessing whether gullies are stable or actively expanding is often of great relevance. While historic expansion of gullies is best assessed through repeated surveys (cf. Section 2.3), this is not always possible. Furthermore, to target mitigation efforts, it is often required to identify the gullies that are currently active (e.g. Whitford et al., 2010). Some morphological characteristics can indicate whether a gully is likely active (Oostwoud Wijdenes et al., 1999). For example, (recently) active gully heads typically have sharp edges, a plunge pool, tension cracks, recently deposited sediments and flow marks. Stabilized gullies typically have smoother or rounded edges and vegetation re-growth on the gully head wall and at its foot (Oostwoud Wijdenes et al., 2000). However, such distinctions are not always detectable on aerial/satellite imagery. Several studies therefore assessed gully stability based on the vegetation cover inside the gully (e.g. Vanwalleghem et al., 2005c; Makanzu Imwangana et al., 2015; Golosov et al., 2018). While such morphological or vegetation criteria can provide strong indications, it is important to note that they are not a guarantee for gully stability. Extreme weather events or significant land cover changes may reactivate gullies that have been stable for many years (Vandekerckhove et al., 2001b).

Likewise, classifying gullies into types (e.g. permanent, ephemeral, bank gully, valley-bottom and valley-side gully) is generally useful, as this may help understanding the causing mechanisms, potential erosion rates and optimal remediation strategies (e.g. Amare et al., 2019; Bartley et al., 2020). Such classifications can be based on the dimensions, the landscape position and/or the land use type in which the gully occurs. However, while there is some agreement on different types of gullies (cf. Section 3), no universal gully classification scheme currently exists. This limits the comparability of gully inventories and, by extent, gully erosion assessments at regional to continental scales. The development of systematic gully typologies, similar to those developed for landslides (e.g. Cruden and Varnes, 1996), may help address this issue.

\subsection{Assessing gully dynamics}

Various studies have assessed gully erosion rates through repeated field surveys or by determining the age of gullies through the analyses of tree roots, terrestrial photography, interviews, optical dating, sediment fingerprinting or other techniques (e.g. Vandekerckhove et al., 2001a, 2003; Martınez-Casasnovas et al., 2004; Ionita, 2006; Nyssen et al., 2006; Marzolff et al., 2011; Frankl et al., 2012; Portenga et al., 2017; Bernatek-Jakiel and Wrońska-Wałach, 2018). While such research can provide key insights, they typically require intensive fieldwork and are therefore generally limited to specific gullies or small study areas. Efforts to understand gully erosion dynamics over larger areas therefore mainly rely on applying the techniques discussed above over different periods (e.g. Nachtergaele et al., 2002b; Vandekerckhove et al., 2003; Vanwalleghem et al., 2005c; Marzolff and Poesen, 2009; Frankl et al., 2011; Yibeltal et al., 2019).

Such analyses based on available imagery typically face important limitations. A first one is the length of the observation period. Given its threshold-dependent nature, gully erosion is often a highly erratic process (e.g. Vandekerckhove et al., 2001b; Martınez-Casasnovas et al., 2004). For example, Hayas et al. (2017a) showed average gully erosion rates may vary up to a factor 60 over short $(<5$ years) observation periods. A global review of observed gully headcut retreat rates indicated similar ranges of variability (Vanmaercke et al., 2016). Hence, average gully erosion rates derived from short observation periods are often subject to very important uncertainties. While these uncertainties generally remain poorly quantified, they may easily dwarf the uncertainties related to assessing gully properties (cf. Section 2.2). These uncertainties are often asymmetric: gully erosion rates derived from short periods are more likely to underestimate the long-term average, but may in some cases result in severe overestimations (Vandekerckhove et al., 2003; Hayas et al., 2017a; Vanmaercke et al., 2016).

Apart from climatic variability, over- or underestimations strongly depend on the timing of the imagery. Permanent gullies often show the highest headcut retreat rates shortly after their formation, but then tend to stabilize over time (e.g. Nachtergaele et al., 2002b; Vanwalleghem et al., 2005a; Sidorchuk, 2006; Whitford et al., 2010; Vanmaercke et al., 2016; Makanzu Imwangana et al., 2015; Rysin, 1998). When gullies are already present on the first image of a series, this poses large challenges in reconstructing the long-term average erosion rate (Vanmaercke et al., 2016). Furthermore, gullies can expand through widening and deepening (e.g. Martınez-Casasnovas et al., 2004; Marzolff and Poesen, 2009). Research suggests that these processes become relatively more important in the later stages of gully development (e.g. Sidorchuk, 1999; Sidorchuk et al., 2003; Sidorchuk, 2006; Hayas et al., 2017a). Nonetheless, few studies have focused on these processes. As a result, they remain poorly quantified and understood (Whitford et al., 2010; Hayas et al., 2019).

Finally, also the timing and frequency of the imagery greatly affects the reliability. Long periods between images make it difficult to accurately assess the initiation of gullies and may lead to biases. This is especially a concern for ephemeral gullies in arable land. As many ephemeral gullies are ploughed away shortly after their formation, assessing their erosion rate based on infrequent imagery can strongly underestimate the actual rate (Nachtergaele and Poesen, 1999). Ideally, imagery should be acquired shortly after every significant rainstorm 
event. However, that is rarely possible and especially hard for large areas. The rise of satellite imagery products with high spatial, temporal and spectral resolutions in combination with (semi-)automatic detection procedures (e.g. Shruthi et al., 2014) may help address this gap.

In conclusion, assessing reliable gully erosion rates at regional to continental scales remains difficult, especially at high temporal resolutions. Methodological challenges in both the detection (cf. Section 2.1) and characterization (cf. Section 2.2) of gullies may induce significant uncertainties. New remote sensing products and (semi-)automatic detection procedures offer promising perspectives here. Nevertheless, especially the large temporal variability that characterizes gully erosion remains a major source of uncertainty. Accurately quantifying gully erosion rates therefore requires frequent imagery over sufficiently long time periods (e.g. decades). Historic (aerial) photographs can be crucial assets in this (e.g. Nachtergaele and Poesen, 1999; Frankl et al., 2011; Golosov et al., 2018). Nonetheless, such photographs are rarely available over large areas, are often difficult to access for scientists and their processing often remains very labour-intensive (e.g. Guyassa et al., 2018).

\section{Measurements on gully erosion in Europe: an overview}

As discussed above, field-based research is important for defining the locations, morphological characteristics, erosion processes, dynamics and controlling factors of gullies. To gain insights into the geographic distribution of field-based gully related research in Europe and European Russia, we conducted a detailed literature review. This review concentrated on research results published in peer-reviewed journals or in conference proceedings. Studies published in internal reports, MSc. or $\mathrm{PhD}$. theses, or newspaper articles (i.e. grey literature) were not considered. As some research teams produced a large number of peerreviewed papers about gullies in particular study areas, only the most relevant papers, considered to be representative for the study area, were selected. In total over 224 research papers have been selected (Table 1). Fig. 2 shows the spatial distribution of areas where permanent, ephemeral or bank gullies as well as gullies in badlands have been studied. Although a large number of papers report on various aspects of badlands, we only considered studies focusing on gully erosion in badlands.

Overall, gully erosion mainly received significant field-based research attention in some particular countries, i.e. Belgium, Germany, Italy, Spain, Romania and the UK. Most studies investigated permanent gullies in forests or rangelands (including badlands; Fig. 2a, d). Relatively fewer studies report on ephemeral gullies, which are typically observed after erosive periods in cropland. As ephemeral gullies are filled in by tillage or land leveling operations shortly after their formation, these gullies are also more difficult to study. Although quite common in rural areas with a rolling or steep topography, bank gullies forming at river banks, agricultural terraces, lynchets or sunken lane banks (Poesen et al., 2003) have also received less attention (Fig. 2c).

Most studies focused on a single gully channel or on a limited number of selected gullies in a particular study area. However, a few studies provide gully inventories for extensive areas $\left(>10,000 \mathrm{~km}^{2}\right)$ or even entire countries (Fig. 3). More specifically, such studies exist for Slovakia (Bučko and Mazúrová, 1958), Poland (Józefaciuk and Józefaciuk, 1983), SE-Poland (Gawrysiak and Harasimiuk, 2012), East Romania (Radoane et al., 1995), Northern France (De Foucault et al., 1997), the Middle Volga region (Russian Federation; Golosov et al., 2018) and Hungary (Kertész and Křeček, 2019). These inventories are largely based on aerial imagery interpretation. They are often already relatively old and focused on larger, permanent gullies. Therefore it is generally difficult to assess their accuracy and completeness. Nonetheless, such inventories may be indispensible for calibrating and validating gully occurrence models at larger scales (cf. Section 4.1).

It is beyond our scope to provide an in-depth review of all aspects of gully erosion that received research attention. Such thematic explorations have been conducted elsewhere (e.g. Poesen et al., 2003; Castillo and Gómez, 2016). Nonetheless, several major themes of gully erosion research in Europe could be identified. These include:

- Developing and testing gully measuring and monitoring techniques, such as high-altitude aerial photograph analysis (e.g. Nachtergaele and Poesen, 1999; Martınez-Casasnovas et al., 2002), analysis of high-resolution aerial photos taken by drones (e.g. Marzolff and Poesen, 2009; Stöcker et al., 2015), 3Dterrestrial image-based modelling (e.g. Frankl et al., 2015) and dendrogeomorphology (Vandekerckhove et al., 2001a; Malik, 2008; Tichavský et al., 2018).

- Dating of (pre-)historic gullies (e.g. Sønstegaard and Mangerud, 1977; Bork, 1985; Dotterweich et al., 2003, 2012, 2013; Schmitt et al., 2006; Vanwalleghem et al., 2006) and investigating the environmental conditions that lead to their initation and development (e.g. Bork, 1985; Faulkner, 1995; Dotterweich et al., 2003; Gábris et al., 2003; Nogueras et al., 2000; Stankoviansky, 2003a, 2003b, 2003c; Vanwalleghem et al., 2005b; Martín-Moreno et al., 2014; Ionita et al., 2015b; Ballesteros Cánovas et al., 2017).

- Investigating factors controlling the initiation and development of contemporary gullies, including soil profile characteristics (e.g. Vanwalleghem et al., 2005b), plant roots (e.g. Gyssels and Poesen, 2003), topography and topographic thresholds (e.g. Vandekerckhove et al., 1998; Souchere et al., 2003; Hayas et al., 2017a, 2017b; Torri et al., 2018b), snowmelt runoff (e.g. Øygarden, 2003; Ionita, 2006; Rodzik et al., 2009; Rysin et al., 2017a; Rysin et al., 2017b; Golosov et al., 2018), rainfall conditions (Hayas et al., 2017a, 2017b) and the role of piping (Bernatek-Jakiel and Wrońska-Wałach, 2018).

- Exploring the conditions leading to the infilling of gullies (e.g. Erikstad, 1992; Vanwalleghem et al., 2005c).

- Evaluating the effectiveness of gully erosion control techniques, including geomembranes (e.g. Poesen, 1989), check dams (e.g. Castillo et al., 2007), grassed waterways (e.g. Evrard et al., 2008) and bioengineering structures (e.g. Rey and Burylo, 2014).

- Quantifying the contribution of gully erosion to catchment sediment yields (e.g. Bogen et al., 1994; Poesen et al., 1996, 2003).

This review also revealed some important research gaps with respect to understanding and quantifying gully erosion at regional to continental scales:

1) Most studies are clustered in specific study areas, while many other areas remain poorly or not investigated (cf. Fig. 2). While these patterns may be partly caused by the absence of gullies, many regions probably remain under-researched.

2) Only few studies investigated gully occurrence on regional or country-wide scales (cf. Fig. 3).

3) Relatively few studies monitored the evolution of gullies over extensive time periods (e.g. $>20$ years). Given their potentially large temporal variability (e.g. Rysin, 1998; Nachtergaele and Poesen, 1999; Martınez-Casasnovas et al., 2004; Vanmaercke et al., 2016; Hayas et al., 2017a; Rysin et al., 2017a; Rysin et al., 2017b; Rysin et al., 2018), this is critical to understand the long-term evolution and erosion rates of gully systems.

4) Relatively few studies have focused on testing or developing models that simulate spatial patterns of gully erosion. This is particularly the case for larger areas.

5) Evaluating the long-term effectiveness and efficiency of gully erosion control measures has received little attention, both at the scale of gully channels and catchments (Poesen et al., 2003; Bartley et al., 


\begin{tabular}{|c|c|}
\hline Country & Ephemeral Gullies \\
\hline Austria & N.A. \\
\hline Belgium & $\begin{array}{l}\text { Govers and Poesen (1988); Vandaele and Poesen (1995); Poesen et al. } \\
\text { (1996); Vandaele et al. (1996); Vandaele et al. (1997); Desmet et al. (1999) } \\
\text { Nachtergaele and Poesen (1999); Takken et al. (1999); Steegen et al. (2000) } \\
\text { Gyssels et al. (2002); Gyssels and Poesen (2003); Vanwalleghem et al. } \\
\text { (2005a); Evrard et al. (2007); Knapen and Poesen (2010); Maugnard et al. } \\
\text { (2014a); Maugnard et al. (2014b) }\end{array}$ \\
\hline Bulgaria & N.A. \\
\hline Croatia & N.A. \\
\hline Czech Republic & Báčová and Krasa (2016); Dumbrovsky et al. (2019) \\
\hline France & $\begin{array}{l}\text { Auzet et al. (1993); Cerdan et al. (2002); Souchere et al. (2003); Frankl et } \\
\text { (2018); Patault et al. (2019) }\end{array}$ \\
\hline Germany & N.A. \\
\hline Greece & Karydas and Panagos (2020) \\
\hline Hungary & N.A. \\
\hline Iceland & N.A. \\
\hline Italy & $\begin{array}{l}\text { Capra and Scicolone (2002); Poesen et al. (2003); Zucca et al. (2006); } \\
\text { Conoscenti et al. (2013); Conoscenti et al. (2014); Fiorucci et al. (2015); } \\
\text { Conoscenti et al. (2018); Conoscenti and Rotigliano (2020) }\end{array}$ \\
\hline
\end{tabular}

Permanent Gullies

Sass et al. (2012)

Arnould-De Bontridder and Paulis (1966); De Ploey (1977); Langohr and Aandes (1985); Gultentops (1992); Posen et

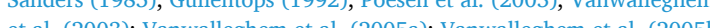

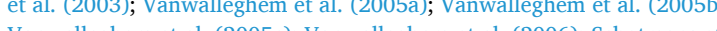
(2015)

Malinov and Ilieva (2017)

Faivre et al.

Tichavský et al. (2018)

De Foucault et al. (1997); Mathys et al. (2003); Rey (2003); Rey (2009);

Erktan and Rey (2013); Rey and Burylo (2014); Taborelli et al. (2016)

Bork and Rohdenburg (1979); Bork (1985); Bauer (1993); Semmel (1995); Bork et al. (1998); Dotterweich et al. (2003); Dotterweich et al. (2003); Heine and Niller (2003); Schmidtchen and Bork (2003); Dreibrodt (2005); Stoly and Grunert (2006); Beyer (2008); Dotterweich (2008); Moldenhaue et al. (2010); Stolz (2011); Dotterweich et al. (2015)

Vandekerckhove et al. (2000)

(2011); Kertész N.A. and Křeček (2019)

Hartmann et al. (2003)

Battaglin et al. (2003); Strunk (2003);

t al. (2009): Buccolini and Coco (2010): Clarke and Rendell (2010);

Battaglia et al. (2011); Cappadonia et al. (2011); Buccolini and Coco (2013); Conoscenti et al. (2013); Pulice et al. (2013); Torri et al. (2013); Vergari et a. (2013a); Caraballo-Arias et al. (2014); Caraballo-Arias et al. (2015); Cocco et al. (2015); Bianchini et al. (2016); Bollati et al. (2019)

\section{Zglobicki et al. (2019)}

N.A.
Øygarden (2003)

Latvia

Norway

Øygarden (2003)

Zgłobicki (1998); Janicki (2014)

Portugal

Poesen et al. (1996); de Figueiredo and Fonseca (1997); Vandaele et a.. (1997); Vandekerckhove et al. (1998); Vandekerckhove et al. (2000b); Nachtergaele et al. (2001a); Poesen et al. (2003)

Romania N.A.

et al. (2020)
Sønstegaard and Mangerud (1977); Erikstad (1992); Bogen et al. (1994) Schmitt et al. (2006); Smolska (2007); Malik (2008); Rodzik et al. (2009); Schmidt and Heinrich (2011); Zgłobicki and Baran-Zgłobicka (2011); (2014); Zgłobicki et al. (2014); Kociuba et al. (2015); Zgłobicki et al. (2015a); Zgłobicki et al. (2015b); Bernatek-Jakiel and Wrońska-Wałach (2018)

de Figueiredo and Fonseca (1997); Vieira et al. (2014); Bergonse and Reis (2016); Martins et al. (2017); Martins et al. (2020)

Motoc (1983); Motoc (1984); Ichim et al. (1990); Radoane et al. (1995); Ionita (2003); Ionita (2006); Mircea (2011); Niacsu and Ionita (2011); Boengiu et al. (2012); Ionita et al. (2015); Radoane and Radoane (2017); Nicu (2018)

Bolysov (1987); Dedkov et al. (1990); Bolysov and Tarzaeva (1996); Rysin (1998); Litvin et al. (2003); Zorina (2003); Belyaev et al. (2004), Belyaev et al. (2005a); Yermolaev (2014); Vanmaercke et al. (2016); Rysin et al Dotterweich et al. (2012); Gawrysiak and Harasimiuk (2012); Superson et al.
Bank Gullies

Gullies in Badlands

N.A

Poesen (1989); Poesen $\quad$ Gullentops (1992);

t al. (1996); Poesen Vanwalleghem et al. (2003);

(2003); Frank et al. Vanwalleghem etal. (2006);
N.A.

N.A.

N.A.

N.A.
NA (2019) Burylo (2014)

N.A.
Mathys et al. (2003); Rey (2009); Erktan and Rey (2013); Rey and

N.A.

N.A.

N.A.

Battaglia et al. (2003); Clarke and Rendell (2006); Ciccacci et a.

(2009); Buccolini and Coco
(2010); Clarke and Rendell

(2010); Battaglia et al. (2011);

Cappadonia et al. (2011);

Buccolini and Coco (2013); Pulice et al. (2013); Torri et al. (2013); Vergari et al. (2013b); CaraballoArias et al. (2014); CaraballoArias et al. (2015); Cocco et al. (2015); Bianchini et al. (2016); Bollati et al. (2019); Bosino et al. (2019); Maerker et al., 2020

N.A.

Erikstad (1992)

N.A

N.A.
N.A. N.A.




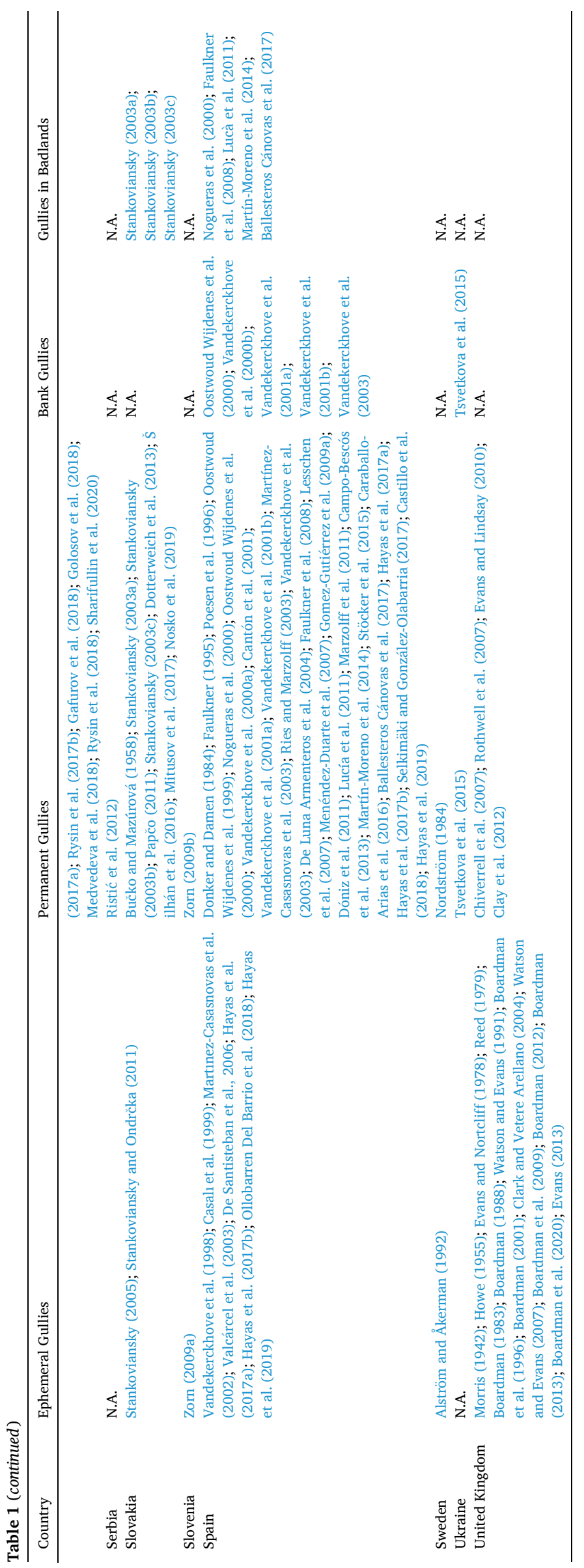

2020). Linked to that, our understanding of the conditions controlling the infilling of gullies is limited (Poesen et al., 2003).

\section{Assessing gully erosion using models}

Predicting gully erosion rates and its impact on sediment loads encompasses several challenges. These include predicting: (i) where and why gullies occur, (ii) when and how these gullies expand, and (iii) to what extent these gullies contribute to catchment sediment yields. Numerous gully erosion models have been developed. However, no single model presently exists that addresses these three components. Furthermore, most modelling efforts have concentrated on individual gullies or local scales. Here we review and discuss different modelling strategies to simulate these different aspects of gully erosion. It is outside our scope to provide a comprehensive overview of all gully erosion models. Instead, we discuss which modelling strategies potentially can be applied at regional to continental scales, which future advancements may be expected and which research needs currently exist.

\subsection{Predicting gully occurrence and density}

Several modelling approaches exist to predict the occurrence of gullies in a landscape (e.g. Poesen et al., 2011). Overall, these can be characterized based on whether they aim to predict the initiation of gullies from process-based principles or whether they aim to predict their occurrence in a purely empirical or statistical way. Most of these involve a combination of both strategies.

In general, process-based approaches rely on the principle that gully initiation is a threshold-dependent phenomenon. Gully heads typically initiate where the shear stress of concentrated runoff exceeds the resisting forces, which mainly depends on local soil and vegetation conditions (Istanbulluoglu et al., 2003; Knapen et al., 2007; Knapen and Poesen, 2010). The most common approach to characterize these conditions is the topographic threshold concept. It builds upon the observation that gullies in a landscape typically form at locations where the upslope area $(A)$ and local slope steepness $(s)$ exceed a certain threshold (e.g. Begin and Schumm, 1979; Montgomery and Dietrich, 1994). Given that $A$ provides a proxy of the potential flow discharge and $s$ influences flow velocity, topographic thresholds directly relate to the critical flow shear stress principle. They are commonly expressed in the form:

$s=k A^{b}$

where $k$ and $b$ are empirically fitted constants that depend on the environmental setting (Begin and Schumm, 1979; Montgomery and Dietrich, 1994; Torri and Poesen, 2014). Such thresholds often allow fairly good identification of the positions of gully initiation within a study area and by extent their density (e.g. Desmet et al., 1999). However, their highly site-specific nature makes them unsuitable for applications at regional or continental scales. A meta-analysis by Torri and Poesen (2014) of 63 s-A relations for various areas worldwide indicated a very large variability in $k$ - and $b$-values (cf. Eq. (1)). Under the assumption that $b$-values are relatively constant, variations in $k$-values seem mainly attributable to differences in land cover. Nonetheless, generalizing these empirical constants remains difficult as also other environmental factors will play a role. For example, a main limitation of topographic thresholds is that they typically reflect the "integrated" result of different gully initiation episodes over time. Exact gully head initiation thresholds vary with rainfall intensity (e.g. Torri and Poesen, 2014; Hayas et al., 2017b) and more specifically with the resulting peak flow discharge. Also spatial patterns of vegetation and soil characteristics within the contributing area can play a large role (e.G. Rossi et al., 2015a). Likewise, the upslope area can be modified by land management practices that are not resolved by DEMs, such as tillage furrows (Souchere et al., 2003), drainage ditches and stone bunds, all of which can affect the $k$-value (Monsieurs et al., 2015). Furthermore, gullies are not 

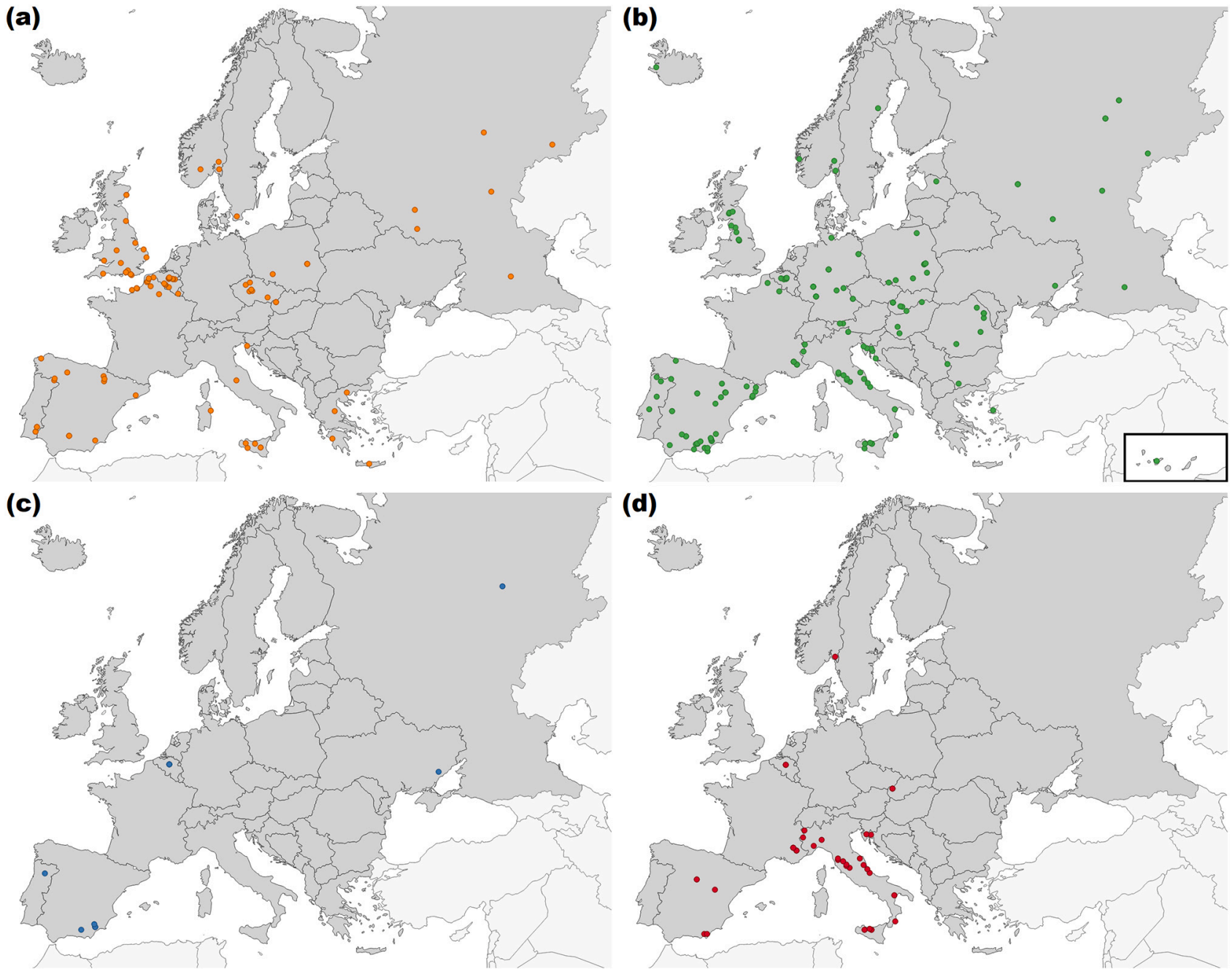

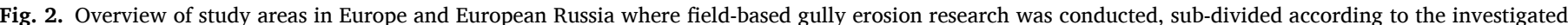

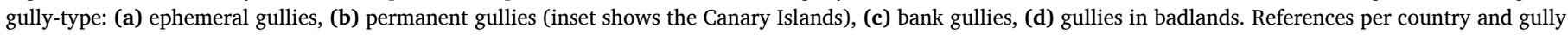
type are listed in Table 1. Countries shaded in dark grey indicate the study area considered for this review.

necessarily the sole result of (Hortonian) runoff. They can also form and expand as a result of saturation soil conditions and overland flow (e.g. Nachtergaele et al., 2001a; Tebebu et al., 2010; Amare et al., 2019).

Alternative topographic indices have therefore been proposed to better reflect landscape positions where gullies may initiate. For example, Moore et al. (1988) proposed an index that accounts for saturation overland flow. Istanbulluoglu et al. (2008) incorporated a probabilistic approach in order to account for uncertainties associated with these kinds of topographic relations. The AnnAGNPS model uses the Compound Topographic Index (CTI) to determine the location of potential ephemeral gullies (Taguas et al., 2012; Momm et al., 2012, 2013). This index is also based on contributing area and slope steepness, but aims to better reflect the potential effect of soil wetness conditions on gully initiation (Momm et al., 2015). Daggupati et al. (2013) compared models based on four different topographic indices, i.e. CTI, slope-area (SA), topographic wetness index (TWI), and slope area power (SAP). Results showed that a SA-based approach predicted ephemeral gully occurrence better than the other models tested. Nevertheless, they also showed that CTI has potential for predicting gully headcut location and total gully length. Conoscenti and Rotigliano (2020) also tested CTI, SA, TWI and modified versions of the latter two (named MspI and MTWI) which incorporate an index to reflect flow convergence/divergence. MspI outperformed the other topographic indices, revealing that a convergence index may help in detecting hollows where gullies are more likely to form. However, local calibration is required (Daggupati et al., 2013). This currently limits regional applications.

To account for factors other than topography (e.g. climate, land use/ land cover, soil type) and their potential interactions, several processoriented model approaches have been proposed. Overall, they aim to replace or complement the upslope contributing area $(A)$ in Eq. (1) with better proxies of flow discharge, and by extent the flow shear stress, that can occur at a potential gully location. This could allow for more accurate and generalizable simulations of where and when gullies may form. Several approaches are based on the Curve Number (CN) method, a simple empirical model that allows estimating runoff based on rainfall, antecedent moisture, soil and land use conditions (e.g. Ponce and Hawkins, 1996). In principle, such approach allows making gully initiation conditions dynamic through time (e.g. Torri and Poesen, 2014; Torri et al., 2018b). Likewise, combining a pixel-based CN approach with flow-routing algorithms makes it possible to account for the effect of spatial patterns of topography, soil conditions and land cover (Rossi et al., 2015a). An attractive element of the $\mathrm{CN}$ approach is that its simple nature enables its application at regional to global scales (e.g. Hong et al., 2007). Nonetheless, this also involves uncertainties and the risk of over-extrapolation as the $\mathrm{CN}$ approach remains an empirical model that was developed and tested for a relatively limited set of environmental conditions. Furthermore, such approach does not yet account for all relevant mechanisms and possible interactions with other erosion 


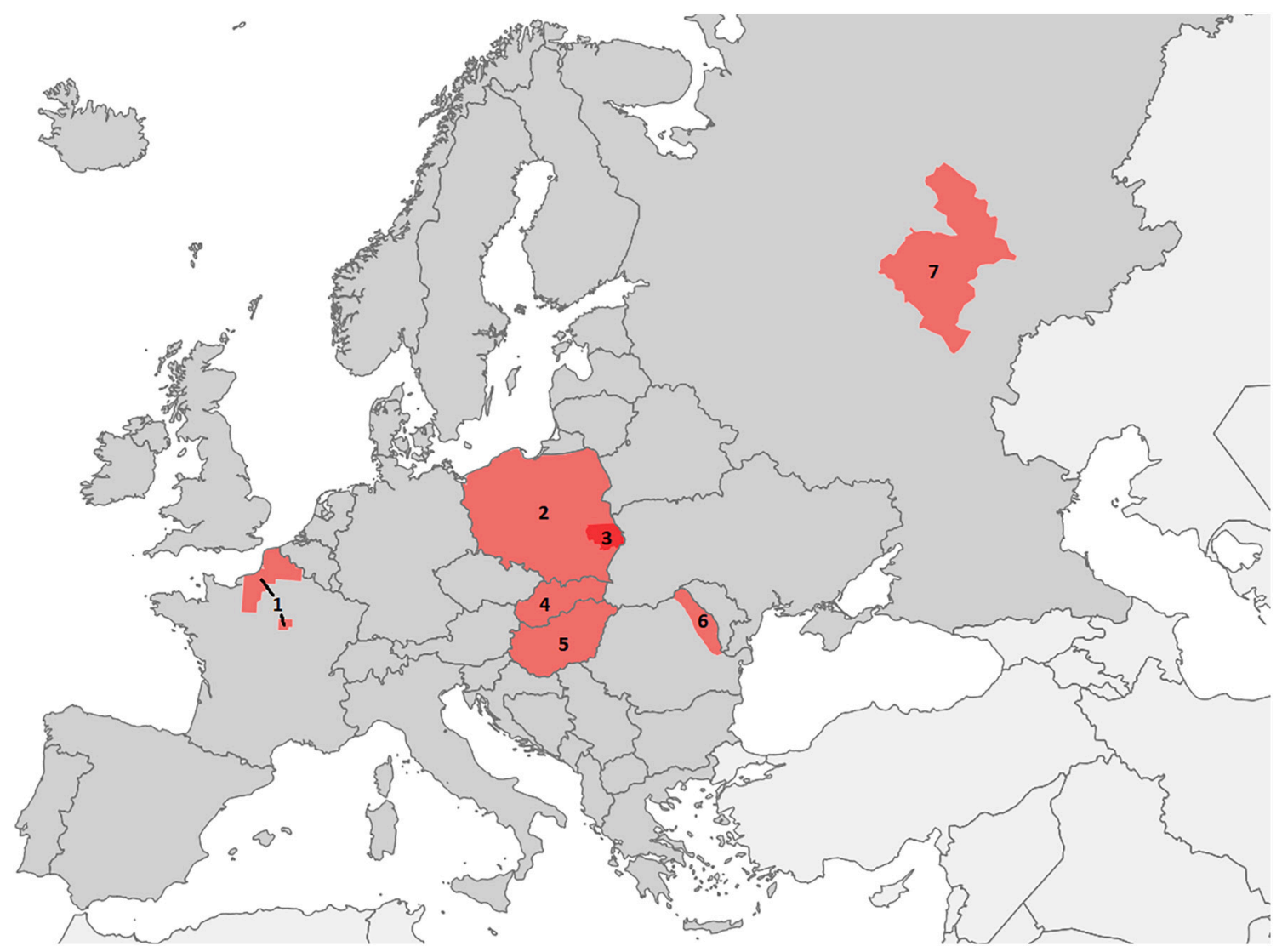

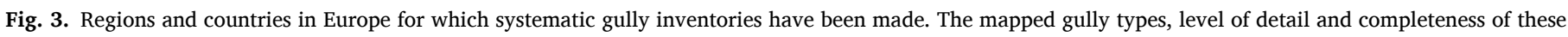

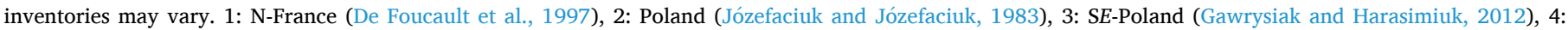

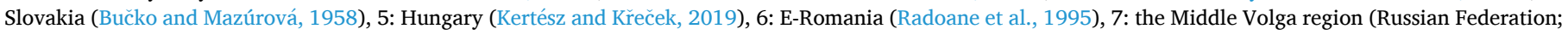
Golosov et al., 2018). Countries shaded in dark grey indicate the study area considered for this review.

processes. For example, also the amount of sediments transported by the runoff from upslope areas will determine whether incision or aggradation will take place (e.g. Poesen et al., 2003).

Also several landscape evolution models are to some extent capable of simulating gully initiation, using a process-based approach (e.g. Tucker et al., 2001; Kirkby et al., 2003; Willgoose, 2005, 2018; Harmon et al., 2019). These typically define the threshold in terms of equilibrium between local sediment load or entrainment and sediment transport capacity; often conceptualized in terms of shear stress or stream power per unit flow width. Nevertheless, some empiricism remains. This mainly relates to the definition of critical flow shear stress and the longterm effects of temporal variations in environmental conditions.

Overall, process-oriented approaches offer significant promise to predict gully initiation as they aim to account for the actual driving processes in a conceptually transparent way. This can make them highly suitable for the evaluation of gully erosion risks in the context of climate or land use changes (e.g. Hancock et al., 2000; Sidorchuk et al., 2001; Sidorchuk et al., 2003; Rossi et al., 2015a). Furthermore, these models may generally allow for a more straightforward and correct coupling between gully initiation and expansion (cf. Section 4.2). Several processoriented gully erosion models already account for both components, and perform acceptably over study sites with reasonably uniform properties (e.g. Willgoose, 2005; Hancock et al., 2015). Nonetheless, the application of most of these models remains limited to theoretical considerations or small study areas (e.G. Rossi et al., 2015a). In many cases, these models also remain poorly validated (Poesen et al., 2011). A major reason for this is the relatively large data requirements (e.g. Kirkby et al., 2003; de Vente et al., 2013). This includes detailed information on the controlling factors, but also observations on gully initiation (e.g. knowing which gully head was initiated and when exactly for a sufficiently long observation period). For the former, the availability of new GIS data layers and products opens promising perspectives (cf. Section 5). Nonetheless, the latter remains a critical point for applications at regional to continental scales (cf. Sections $2 \& 3$ ). As with most geomorphic models, also error propagation is a critical concern. Accurate process descriptions of gully initiation typically require more input data. Errors and uncertainties on these input data can easily become more important than errors and uncertainties resulting from an inaccurate process description (e.g. Van Rompaey et al., 2002).

Empirical approaches to simulate gully occurrence and densities can offer a major advantage in this regard: they typically result in more robust predictions and are often less demanding in terms of data requirements (e.g. de Vente et al., 2013). Overall, a wide range of empirical approaches exist. To some extent, they can be classified in bivariate methods, multivariate methods, and machine learning approaches. An (non-exhaustive) overview of example studies is given in Table 2. Most of these procedures aim to predict the presence or absence of a gully on a given location. Their successful application results in a gully erosion susceptibility map (GESM), from which proxies of gully density can be derived. However, some approaches try to directly predict the gully density within a catchment (Zhao et al., 2016) or pixel (Kheir et al., 2007; Vanmaercke et al., 2020).

Bivariate statistical approaches (e.g. Conforti et al., 2011; Conoscenti et al., 2013) can be robust but reduce gully prediction to only one causal factor, typically leading to imprecise predictions. Except in simple situations or very data-poor regions, these approaches are therefore generally inferior to the other methods. Multivariate methods (e.g. Akgün and Türk, 2011; Lucà et al., 2011) analyse gully occurrence as a function of different causal factors and to some extent allow determining the relative contribution of each factor. Logistic regression (e.g. 
Table 2

Examples of empirical gully occurrence and gully density models.

\begin{tabular}{|c|c|c|c|c|}
\hline Method & Sub method ${ }^{\mathrm{a}}$ & Authors & Scale $\left(\mathrm{km}^{2}\right)$ & location \\
\hline \multirow[t]{6}{*}{$\begin{array}{l}\text { Bivariate } \\
\text { statistical }\end{array}$} & $\begin{array}{l}\text { Conditional } \\
\text { analysis }\end{array}$ & Conoscenti et al., 2013 & 250 & Italy \\
\hline & Index of entropy & Zabihi et al., 2018; Arabameri et al., 2018b & $15.44-416$ & Iran \\
\hline & $\begin{array}{l}\text { Information } \\
\text { value }\end{array}$ & Lucà et al., 2011; Conforti et al., 2011; Al-Abadi and Al-Ali, 2018 & $26,74-30$ & Iran, Italy \\
\hline & EBF & Al-Abadi and Al-Ali, 2018 & 26,74 & Iran \\
\hline & Frequency ratio & Al-Abadi and Al-Ali, 2018; Rahmati et al., 2016; Zabihi et al., 2018; Arabameri et al., 2018b & $15,44-2.595$ & Iran \\
\hline & $\begin{array}{l}\text { Weights of } \\
\text { evidence }\end{array}$ & Rahmati et al., 2016; Arabameri et al., 2018b; Zabihi et al., 2018 & $15,44-2.595$ & Iran \\
\hline $\begin{array}{l}\text { Multivariate } \\
\text { statistical }\end{array}$ & $\begin{array}{l}\text { Logistic } \\
\text { regression }\end{array}$ & Akgün and Türk, 2011; Lucà et al., 2011; Conoscenti et al., 2014; Maerker et al., 2020 & $9,5-424$ & Italy, Turkey \\
\hline \multirow[t]{9}{*}{ Machine learning } & AHP & Arabameri et al., 2018b & 416 & Iran \\
\hline & ANN & Pourghasemi et al., 2017 & 2595 & Iran \\
\hline & BRT & Maerker et al., 2011, 2020; Angileri et al., 2016; Rahmati et al., 2017; Arabameri et al., 2018a & $245-848$ & Iran \\
\hline & CRT & Kheir et al., 2007; Geissen et al., 2007; Gomez-Gutiérrez et al., 2009b; Maerker et al., 2011 & $26,4-3500$ & $\begin{array}{l}\text { Spain, Turkey, Mexico, } \\
\text { Italy }\end{array}$ \\
\hline & FDA & Gayen et al., 2019 & 709 & India \\
\hline & MARS & $\begin{array}{l}\text { Gomez-Gutiérrez et al., 2009b; Gómez-Gutiérrez et al., 2009c; Gómez-Gutiérrez et al., 2015; } \\
\text { Arabameri et al., 2018a; Gayen et al., 2019; Conoscenti et al., 2018; Conoscenti and Rotigliano, } \\
2020\end{array}$ & $9,5-848$ & India, Spain, Iran, Italy \\
\hline & $\begin{array}{l}\text { Maximum } \\
\text { entropy }\end{array}$ & Zakerinejad and Maerker, 2014; Pourghasemi et al., 2017; Maerker et al., 2020 & 2595 & Iran, Italy \\
\hline & Random forest & $\begin{array}{l}\text { Kuhnert et al., 2010; Rahmati et al., 2017; Arabameri et al., 2018a; Gayen et al., 2019; } \\
\text { Vanmaercke et al., } 2020\end{array}$ & $245-848$ & $\begin{array}{l}\text { India, Iran, Australia, } \\
\text { Horn of Africa }\end{array}$ \\
\hline & SVM & Rahmati et al., 2017; Pourghasemi et al., 2017; Gayen et al., 2019; & $245-2.595$ & India, Iran \\
\hline
\end{tabular}

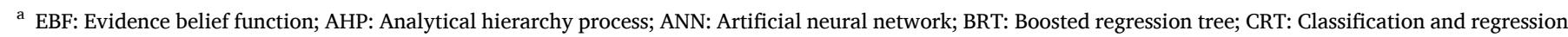
tree; FDA: Flexible discriminant analysis; MARS: Multivariate adaptative regression spline; SVM: Support vector machine.

Vanwalleghem et al., 2008; Conoscenti et al., 2014; Dewitte et al., 2015) is the most commonly used multivariate approach. Its computational simplicity and ability to deal with both continuous and categorical explanatory variables are important advantages. However, its ability to fully disentangle the potentially non-linear role of different factors and their interactions remains limited. In this regard, machine learning methods offer great potential and have been increasingly used over recent years (Table 2). Especially techniques like random forests (e.g. Gayen et al., 2019; Rahmati et al., 2017; Hosseinalizadeh et al., 2019) can, at least in principle, better account for the fact that the role of explanatory variables may vary between different subpopulations of gullies and over different scales. They can also be used to spatially assess uncertainties on model outputs, thus guiding interpretation and targeting further data collection (e.g. Kuhnert et al., 2010; Vanmaercke et al., 2020).

Given their typically smaller data requirements as compared to process-oriented models, empirical approaches could be suitable to predict gully occurrence at regional to continental scales (e.g. Hughes and Prosser, 2012; de Vente et al., 2013). However, most empirical modelling studies focus on relatively small study areas (Table 2). Jurchescu and Grecu (2015) compared gully prediction performances with regression trees at different spatial scales. They report that predictions at the regional scale are affected by larger uncertainties as compared to predictions for smaller areas. A main limitation lies in the need for gully inventories at regional to continental scales in order to calibrate and validate such models. As discussed in Sections 2 and 3, such inventories remain scarce as they are labour-intensive to compile. Another important constraint of such empirical models is that they generally remain 'black box' approaches. While they can provide some insight into the dominant factors controlling gully occurrence, the underlying mechanisms and interactions are generally less clear (e.g. Zhao et al., 2016). This may limit the potential of such empirical approaches for scenario analyses, especially in the case of machine learning techniques.

Models aiming to predict gully initiation and densities at regional to continental scales in the context of future climate or land use changes should therefore seek to strike a balance between a relevant and conceptually sound process description and feasible calculation and input requirements. Several studies already apply a hybrid approach between empirical and process-based gully occurrence prediction. For example, Dewitte et al. (2015) implemented a two-step procedure. First, potentially gully-prone areas were delineated based on the slope-area threshold concept. Next, logistic regression was used for a more detailed prediction of gully locations within those areas. Recent conceptual advancements that replace the slope-area threshold concept with more detailed description of expected runoff discharges (e.g. based on the $\mathrm{CN}$-model approach; see above), also offer promising perspectives in this regard.

\subsection{Predicting gully expansion}

Total gully erosion rates over an area not only depend on the occurrence of gullies (cf. Section 4.1), but also on their expansion rates. Actively eroding gullies generally produce sediment through headcut retreat and channel widening/deepening (e.g. Martınez-Casasnovas et al., 2004; Marzolff and Poesen, 2009; Vanmaercke et al., 2016; Hayas et al., 2017a). In some contexts, piping can also contribute significantly to gully expansion (e.g. Valentin et al., 2005; Bernatek-Jakiel and Poesen, 2018).

Table 3 shows a (non-exhaustive) overview of models that have been developed to predict gully expansion. Gully headcut retreat is generally the best-studied expansion process and several process-oriented models have been developed to simulate this. Examples include CHILD for permanent gullies (Flores-Cervantes et al., 2006) or the module TIEGEM within AnnAGNPS for ephemeral gullies (Gordon et al., 2007). Both are based on a model simulating the hydraulics at the gully head by Alonso et al. (2002). While field validation of its predecessor, EGEM (Woodward, 1999), revealed important flaws, TIEGEM tends to show better model performances. Nonetheless, testing currently remains limited. Also evaluations of CHILD showed that it is capable of reproducing observed retreat rates relatively well, at least in some contexts (e.g. Campo-Bescós et al., 2013). However, its application requires several parameters that generally need to be obtained in the field (including the height of the headcut, the shape of the plunge pool and soil erodibility). This greatly limits its use at larger scales. This problem is not specific to the CHILD model, but affects most process-based gully headcut retreat 
models (e.g. Poesen et al., 2011). Another important limitation are the often high data requirements needed to accurately predict peak runoff discharges and flow velocities at the gully head. This is a common challenge for ungauged basins (Blöschl, 2006). More simplified approaches that predict headcut retreat based on (hydrological) model routines that require fewer and feasible parameters therefore show greater promise at larger scales but require further development and field validation (e.g. Dabney et al., 2015; Allen et al., 2018).

As with gully occurrence (cf. Section 4.1), empirical models based on statistical correlations between observed headcut rates and environmental variables may offer an alternative (Table 3). Several studies proposed empirical equations predicting gully headcut retreat rates for specific study sites (e.g. Vandekerckhove et al., 2003; Marzolff et al., 2011; Poesen et al., 2011; Frankl et al., 2012; Li et al., 2015). These models differ strongly in terms of incorporated factors. However, a meta-analysis of $>700$ measured volumetric headcut retreat rates worldwide showed that the upslope contributing area $(A)$ of the gully headcut and the rainfall intensity (expressed as the rainy day normal, i.e. the average annual rainfall depth divided by the average number of rainy days) are key factors (Vanmaercke et al., 2016). Combined, these two variables explained nearly $70 \%$ of the observed global variation in headcut retreat rates. As such, this opens promising perspectives to predict gully headcut retreat at regional to continental scales. Nonetheless, several important challenges remain. For example, applying this model to local or regional contexts can result in significant uncertainties. More accurate predictions will likely require the incorporation of land use and other controlling factors (Vanmaercke et al., 2016). Furthermore, its application requires knowing $A$ and, by extent, the position of each headcut. Therefore, successfully predicting gully erosion rates at regional to continental scales will likely need the coupling of a headcut retreat model component to a module that simulates where these headcuts occur. Hybrid approaches that combine a simple hydrological model with empirical components are promising in this regard (cf. Section 4.1).

Relatively fewer studies focussed on gully widening and deepening. Nonetheless, also they can contribute significantly to gully expansion (e. g. Martınez-Casasnovas et al., 2004; Hayas et al., 2017a). Some processoriented models for gully-widening and deepening have been proposed (e.g. Sidorchuk, 1999, Sidorchuk et al., 2003; Table 3). However, as with gully initiation (cf. Section 4.1) and headcut retreat, their application at regional or continental scales is severely impeded by high data requirements. For example, Istanbulluoglu et al. (2005) present a model to predict gully widening by slab failures, but this requires knowing the slab geometry beforehand. Nevertheless, more simplified approaches applicable at larger scales are likely possible. For example, Crouch (1987) indicated the potential of gully sidewall to assess relative differences in erosion rates. Martınez-Casasnovas et al. (2004) successfully used logistic regression to predict gully wall failures in the Penedes region (Spain). Likewise, based on the analyses of gully widening rates in SW Spain, Hayas et al. (2019) developed a simple empirical model that relates gully widening to the upslope contributing area (A) and daily rainfall depth thresholds. This model shows strong similarities with the above-discussed global empirical model for gully headcut retreat rates (Vanmaercke et al., 2016). This suggests that developing relatively simple, integrated models of gully expansion should be possible. However, more research on the factors controlling gully widening and deepening across contrasting environments, as well as their associated time scales, is needed (e.g. Graf, 1977).

Table 3

Overview of process-oriented and empirical gully expansion models.

\begin{tabular}{|c|c|c|c|c|c|c|}
\hline Type & Model name & References & $\begin{array}{l}\text { Gully } \\
\text { type }^{\text {a }}\end{array}$ & $\begin{array}{l}\text { Process } \\
\text { modelled }^{\mathrm{b}}\end{array}$ & $\begin{array}{l}\text { Main input } \\
\text { parameters }^{c}\end{array}$ & Field observations ${ }^{\mathrm{d}}$ \\
\hline \multirow[t]{9}{*}{$\begin{array}{l}\text { Process- } \\
\text { Oriented }\end{array}$} & $\begin{array}{l}\text { DIMGUL, } \\
\text { STABGUL }\end{array}$ & Sidorchuk (1999); Sidorchuk et al. (2003) & PG & GHL, GW, GD & Ac, S, Q, K & $\begin{array}{l}\text { Russia }(n=1) \text {, Australia }(n=1) \text {, Swaziland } \\
(n=1)\end{array}$ \\
\hline & EGEM & $\begin{array}{l}\text { Nachtergaele et al. (2001a, 2001b); Capra } \\
\text { et al. (2005); Tekwa et al. (2015) }\end{array}$ & EG & $\mathrm{GHL}^{\mathrm{f}}$ & Aa, Ac, Pe, K, D & $\begin{array}{l}\text { Belgium }(n=116) ; \text { Spain \& Portugal }(n= \\
\text { 86); Italy }(n=92) ; \text { Nigeria }(n=12)\end{array}$ \\
\hline & $\begin{array}{l}\text { AnnAGNPS- } \\
\text { TIEGEM }^{\mathrm{e}}\end{array}$ & Gordon et al. (2007) & EG & $\mathrm{GHL}^{\mathrm{f}}$ & Ac, M, Q, K, D & US $(n=4)$ \\
\hline & CHILD $^{\mathrm{e}}$ & $\begin{array}{l}\text { Flores-Cervantes et al. (2006); Campo- } \\
\text { Bescós et al. (2013) }\end{array}$ & PG & GHL & Ac, M, Q, K, D & no; Spain $(\mathrm{n}=1)$ \\
\hline & CHILD & Istanbulluoglu et al. (2005) & PG & GW & $\begin{array}{l}\text { Aa, Ac, Pe, M, K, } \\
\text { D }\end{array}$ & no \\
\hline & - & Rengers and Tucker (2014) & PG & GHL & $\begin{array}{l}\text { Aa, Ac, Pe, M, K, } \\
\text { D }\end{array}$ & no \\
\hline & LANDPLANER & $\begin{array}{l}\text { Rossi (2014); Rossi et al. (2015a); Rossi } \\
\text { et al. (2015b) }\end{array}$ & PG & $\mathrm{GH}, \mathrm{GA}$ & $\begin{array}{l}\text { Aa, Ac, S, Pe, Q, } \\
\text { M }\end{array}$ & Italy \\
\hline & EphGEE & Vieira et al. (2015); Dabney et al. (2015) & EG & GHL & $\mathrm{Q}, \mathrm{K}$ & $\mathrm{US}(\mathrm{n}=\mathrm{NA})$ \\
\hline & SWAT-DEG & Allen et al. (2018) & EG & $\mathrm{GHL}^{\mathrm{f}}$ & Ac, Q, K, D & US $(n=3)$ \\
\hline \multirow[t]{11}{*}{ Empirical } & regression & Vanmaercke et al. (2016) & PG, EG & GHV & $\mathrm{Aa}, \mathrm{Pa}$ & global $(n=724)$ \\
\hline & regression & Li et al. (2015) & PG & GA & Aa, Ac, S & China $(n=30)$ \\
\hline & regression & Frankl et al. (2012) & PG & GHV & $\mathrm{Aa}$ & Ehtiopia $(n=18)$ \\
\hline & regression & Marzolff et al. (2011) & PG & GHV & $\mathrm{Aa}, \mathrm{Pe}$ & Spain $(\mathrm{n}=9)$ \\
\hline & regression & $\begin{array}{l}\text { Vandekerckhove et al. (2001a), } \\
\text { Vandekerckhove et al., } 2003\end{array}$ & PG & GHV & $\mathrm{Aa}$ & Spain $(n=46, n=12)$ \\
\hline & regression & Burkard and Kostaschuk (1997) & PG & GA & Aa & Canada $(n=44)$ \\
\hline & regression & Radoane et al. (1995) & PG & GHL & Aa, Ac, Gl & Romania \\
\hline & regression & Stocking $(1980,1981)$ & PG & GHV & Aa, D & US $(n=66)$ \\
\hline & regression & US Soil Conservation Service (1966) & PG & GHL & Aa, $\mathrm{Pe}$ & US $(n=210)$ \\
\hline & regression & Seginer (1966) & PG & GHL & $\mathrm{Aa}$ & Israel \\
\hline & regression & Thompson (1964) & PG & GHL & Aa, S, Pe, K & US \\
\hline
\end{tabular}

\footnotetext{
a PG: permanent gully, EG: ephemeral gully.

b GHL: linear gully headcut retreat, GHV: volumetric gully headcut retreat, GW, gully widening, GD: gully deepening, GA = gully area.

c Aa: catchment area, Ac: catchment characteristics (slope, length, CN, etc.), S: local slope at gully head, Pa: average rainfall data, Pe: event rainfall data, M: gully headcut morphology, Q: flow discharge, K: soil data (e.g. critical shear stress, soil cohesion, ...), D: (maximum) gully depth, Gl: gully length.

$\mathrm{d}$ For process-oriented models $\mathrm{n}$ refers to the gully validation years (i.e. number of gullies times the period over which they were evaluated); for empirical models $n$ refers to the number of data points used for establishing the regression equation.

e Based on Alonso et al. (2002) hydraulic "plunge-pool" model.

f The model simulates gully headcut retreat, however gully widening and deepening are estimated through empirical formula based on flow discharge.
} 
Also piping may contribute significantly to gully initiation and expansion, but no model currently exists that can predict the location and rate of this process, nor its contribution to gully erosion (BernatekJakiel and Poesen, 2018). Furthermore, there is a large need for tools and models that can evaluate and predict how gully expansion rates will evolve in response to gully remediation and, by extent, assess the optimal spacing and dimensioning of such measures. This topic has received relatively little research attention (Bartley et al., 2020; Frankl et al., 2021). For example, some studies provide conceptual (e.g. Castillo et al., 2014b) or empirical (e.g. Pederson et al., 2006) strategies to determine the spacing of check dams. However, their applicability at regional to continental scales largely remains to be developed.

\subsection{Predicting the contribution of gullies to catchment sediment yield}

Several studies already attempted to account for the contribution of gully erosion to catchment sediment yields (SY) via an empirical approach. These studies mostly rely on directly correlating observed SY to proxies of average gully densities (e.g. Zhao et al., 2016) or, alternatively, a semi-quantitative score describing the overall presence of gullies in the catchment in combination with other factors (e.g. de Vente et al., 2005, 2006; Haregeweyn et al., 2005). These approaches generally result in good model performances, while their relatively low data requirements make it feasible to apply them at larger scale. However, they also come with limitations. First, these are spatially lumped models that do not account for spatial patterns of gully densities. Second, they often depend on expert-based judgments of the presence and importance of gullies (e.g. de Vente et al., 2005, 2006) and therefore may not always be perfectly reproducible and objective. Third, factors controlling gully formation typically also control other erosion processes and sediment yields (e.g. steeper topography, erodible soils, limited vegetation cover; Syvitski and Milliman, 2007; Pelletier, 2012; Vanmaercke et al., 2014). Hence, it is often hard to tell to what extent observed correlations between proxies of gully density and SY are indeed attributable to the gullies or to inter-correlations with other factors. On the other hand, factors known to drive gully erosion (e.g. rainfall intensity; Vanmaercke et al., 2016; Hayas et al., 2017b) are not always incorporated in these models because they did not reveal a statistically significant correlation (e.g. de Vente et al., 2005; Zhao et al., 2016). These limitations make such empirical approaches often unsuitable for land or climate change scenario analyses or for developing detailed catchment management strategies (de Vente et al., 2013). Nevertheless, such models may be useful for predicting SY at regional to continental scales.

To address these shortcomings, several studies aimed to model the contribution of gully erosion in a more spatially explicit and processoriented way. Some studies have adapted sediment yield models like SWAT or WATEM-SEDEM. They generally predict SY by estimating sheet and rill erosion rates and then accounting for sediment deposition between the hillslopes and river system (e.g. Van Rompaey et al., 2001; Vigiak et al., 2017). By changing some of the model assumptions or parameters, these models may partially account for gully erosion (e.g. Verstraeten et al., 2007; Easton et al., 2010). Nonetheless, such approaches remain difficult to parameterize and validate and are conceptually problematic, especially in the case of permanent gullies (e. g. de Vente et al., 2013).

Other studies have attempted to directly account for gully erosion by incorporating spatially explicit estimates of gully-prone areas in combination with other factors describing erosion and sediment transfers (e. g. de Vente et al., 2008; Haregeweyn et al., 2017). Identifying gullyprone areas is typically based on the slope-area threshold concept (cf. Section 4.1; Eq. (1)), while their contribution to SY is either based on an empirical estimate of typical gully erosion rates (Haregeweyn et al., 2017) or through model calibration with observed SY (de Vente et al., 2008). Apart from being spatially explicit, this may also avoid the problem of reproducibility mentioned above. Nonetheless, these approaches remain relatively rudimentary and scarcely applied. Wilkinson et al. $(2009,2014)$ developed a more elaborate strategy where detailed maps of existing gullies underpin estimates of the contribution of gully erosion to the sediment budget, based on the volumetric expansion rates of gullies over time. This approach incorporates ancillary information on the relative development stage of the gully networks and the fraction of soil textures likely to contribute to suspended sediment loads. However, the requirement for gully mapping limits easy applications at larger scales. One of the most complete models to date that allows accounting for the effect of gully erosion on SY is AnnGNPS (Momm et al., 2012). It can identify gully mouth locations semi-automatically with the APET tool. This could allow calculating the spatial contribution of gully erosion to SY and evaluating the effect of gully conservation measures at catchment scale. Nevertheless, its applicability over larger areas remains currently unknown.

An additional challenge lies in the fact that gullies not only directly influence SY by contributing sediments, but also indirectly by altering the runoff and sediment connectivity between hillslopes and river systems (e.g. Poesen et al., 2003; Martineli Costa and Bacellar, 2007; de Vente et al., 2008). They can significantly increase sediment connectivity (e.g. Ionita et al., 2015a) but also temporally store sediments (e.g. Taylor et al., 2018). Especially vegetated gullies can function as significant runoff and sediment traps (e.g. Zierholz et al., 2001; Rey et al., 2007; Molina et al., 2009). The same holds for check dams built in gullies (e.g. Castillo et al., 2007; Frankl et al., 2013; Guyassa et al., 2017). In addition, high gully densities may lead to more direct rainfallrunoff responses (e.g. Martineli Costa and Bacellar, 2007) and therefore potentially higher floodplain deposition rates, as riverbank overtopping may occur more frequently. While different modelling approaches for sediment connectivity already exist (e.g. Borselli et al., 2008; Vigiak et al., 2012), their suitability to deal with sediment transfers by gullies remains largely untested. Their application would also require information on the spatial extent of gully networks as well as on their vegetation cover and the presence of check dams or similar measures. As such, assessing both the direct and indirect contribution of gullies to catchment SY at large scales remains very difficult, in particular because the necessary data (e.g. inventories of gullies and gully control measures) remain mostly unavailable.

\section{Model input data at the continental scale}

Modelling gully erosion not only requires observations on gully occurrence and dynamics (cf. Sections 2 and 3). It also requires input data on the environmental factors controlling gully erosion, more specifically the (i) topography, (ii) vegetation cover, (iii) land cover, use and management, (iv) soils and lithology and (v) climate and weather conditions. The availability and quality of input data condition the type of model that can be used (cf. Section 4). Input data for small study areas can be acquired with field-based methods. Gully erosion modelling at regional to continental scale generally needs to rely on Earth Observation (EO) data. The spatial resolutions, revisiting times and level of detail of such EO data have significantly increased over the past decades (e.g. Belward and Skøien, 2015). Continental to global EO-derived datasets are also made increasingly publically available. Furthermore, an increasing number of cloud-based data processing platforms are developed in order to deal with the associated increasing demands for data storage and processing power. These include the Copernicus Data and Information Access Services (DIAS) launched by the European Commission in 2018 and the Google Earth Engine platform.

While datasets at the national level often provide higher resolutions and levels of detail, continental to global datasets have the great advantage of providing harmonized information. The use of national datasets for regional to global scale modelling is often hampered by their fragmentary availability, varying data acquisition and treatment methods and possibly limited data access (e.g. Höfle and Rutzinger, 2011; Lohani et al., 2018). Such lack of harmonization can introduce additional important uncertainties. 
Hence, this review section aims to provide an overview of currently available harmonized (and ideally free) datasets that can be used for gully erosion modelling at regional to continental scales. We focus on data products that are available at a European or global scale. Based on our understanding of the factors controlling gully erosion and expansion, we discuss datasets describing the (1) topography, (2) vegetation cover, (3) land cover, use and management, (4) soil properties and lithology, and (5) climate. The datasets presented and discussed below were selected based on their relevance, up-to-datedness, accuracy, length of observation periods and frequency of updates. It is expected that with the increasing availability of EO data, additional datasets will become available in the near future.

\subsection{Topography}

Topographic variables play a key role in the prediction of both gully initiation and expansion. The most relevant factors are the local slope steepness and the topographic area draining to a specific point in the landscape (cf. Sections 4.1, 4.2). Such information can be derived from digital elevation models (DEMs). Remotely-sensed DEMs for areas of limited spatial extent have been obtained from stereoscopic aerial image analysis or airborne LiDAR for decades. Numerous countries nowadays produce national DEMs based on airborne LiDAR surveys down to submeter pixel size (e.g. Lohani et al., 2018). Here we focus on DEMs having a (nearly) global or European coverage (Table 4).

Among the first near-global DEM datasets derived from spaceborne observations were the SRTM-C DEM (first released in 2003; Rabus et al., 2003), the ASTER GDEM (released 2009) and the improved ASTER GDEM2 (released 2011; Tachikawa et al., 2011) and ASTER GDEM3 (released 2019). While SRTM-C and the more recent TanDEM-X DEM (Krieger et al., 2007) are based on interferometric Synthetic Aperture Radar (SAR) image analysis, ASTER GDEMs and the ALOS DEMs (Tadono et al., 2014; Takaku et al., 2014) are derived from stereoscopic analysis of optical satellite images. All these global DEMs can be considered as Digital Surface Models (DSMs), i.e. the elevation values reflect the Earth's surface including objects such as vegetation and buildings. Furthermore, most of these global DEMs are based on observations collected over longer time periods. Only the SRTM data collection was conducted over only eleven days (in February 2000) and thus reflects the surface elevation at a fairly specific moment (Rabus et al., 2003).

As the data source documentation and various comparison studies indicate (see e.g. review by Alganci et al., 2018), the vertical accuracies of these DEMs strongly depend on the terrain characteristics. Among the publically available global DEMs with finer spatial-resolution $(\leq 30 \mathrm{~m}$ grid spacing), Purinton and Bookhagen (2017) found that STRM-C, ALOS World 3D and TanDEM-X provide the highest vertical accuracies (below $3.5 \mathrm{~m}$ ). This estimate was based on a large number of GPS reference measurements across a wide range of terrain types and elevations. Apart from freely available datasets, some commercial global DEMs have also been recently released (e.g. TanDEM-X, ALOS World 3D; Table 4). These generally have higher spatial resolutions. Based on the same GPS reference dataset, vertical accuracies of both datasets were assessed to be below $2 \mathrm{~m}$ (Purinton and Bookhagen, 2017). Several authors have also assessed the suitability of these global DEMs for geomorphological and hydrological analyses in different landscapes (see e.g. Purinton and Bookhagen, 2017; Boulton and Stokes, 2018; Mondal et al., 2017).

Despite their lower spatial resolution and accuracies as compared to airborne LiDAR DEMS, these global satellite-derived DEMs (Table 4) remain the only consistent, harmonized datasets at regional to continental scales in almost all regions of the world. Among them, the TanDEM-X and the ALOS World 3D (AW3D5) are the best available products. However, their high cost and the computing resources required to use them may pose limitations to continental or global modelling efforts.

\subsection{Vegetation cover}

Also vegetation is generally considered as a key controlling factor of gully erosion and its impacts on SY (cf. Section 4). Overall, a negative relation between vegetation cover and gully density/erosion can be expected as (i) plant material at the surface can slow down flow velocities and reduce runoff shear stresses; (ii) below-ground biomass (in particular plant roots) can increase the soil cohesion; and (iii) vegetation can affect the soil structure and soil hydrological balance, leading to lower runoff production rates (e.g. Gyssels and Poesen, 2003; Knapen et al., 2007; Vannoppen et al., 2015).

Various indices exist to map patterns of vegetation cover from satellite imagery and several publically available, ready-to-use, datasets exist (Table 5). The most commonly used proxy for vegetation cover is the Normalized Difference Vegetation Index (NDVI). Various studies successfully used NDVI as a predictor for gully densities (e.g. Zhao et al., 2016; Vanmaercke et al., 2020). Nonetheless, also other indices may be useful for gully erosion modelling, e.g. the Soil-Adjusted Vegetation Index (SAVI) and the Modified SAVI. Bannari et al. (1995) and Barati et al. (2011) provide reviews of these different indices. While such indices provide proxies for plant biomass and productivity, biophysical variables like the leaf area index (LAI), the fraction of absorbed photosynthetically active radiation (FAPAR) and the fraction of green vegetation cover (Fcover or FVC) provide more physically-based descriptions of the vegetation cover. The latter is particularly relevant in the context of soil erosion susceptibility (Panagos et al., 2015a; Borrelli et al., 2017b). It corresponds to the fraction of green vegetation, covering the ground as seen from the nadir direction. Similarly, Vegetation Continuous Fields (VCF) provides estimates of vegetation cover as the percentage of tree cover, percentage of non-tree vegetation, and percentage of non-vegetated area (e.g. Sexton et al., 2013). An important limitation of these EO-derived indices is that they only relate to the above-ground vegetation. Currently, information on below-ground biomass can only be indirectly estimated (e.g. based on above-ground vegetation characteristics, in-situ data and expert knowledge). Nevertheless, important progress has recently been made in this regard. For example, based on empirical modelling, Fan et al. (2017) provide estimates of maximum rooting depth at a global scale.

Table 5 lists a selection of publically available global NDVI and FCover datasets. They were selected because they are free, have a high spatial resolution (1 $\mathrm{km}$ or finer), are based on a sufficiently long observation period (at least several years) and can be considered representative for the current vegetation cover (i.e. their observation period includes recent years). Several of these datasets are regularly updated. Most of these selected datasets are derived from the analysis of MODIS, Proba-V, Spot Vegetation, and Landsat satellite imagery. They provide temporal coverages ranging from 8-day composites to annual composites. However, some of these series (especially monthly and submonthly Landsat composites) contain gaps due to cloud or snow cover. Datasets based on Landsat imagery currently provide the highest spatial detail, with $30 \mathrm{~m}$ grid spacing for continental to global products.

\subsection{Land cover, use and management}

While vegetation cover refers to the quantity of above-ground biomass (see Section 5.2), land use and land cover (LULC) datasets classify the land surface in categories describing how the land is used. Many of the currently existing modelling tools (e.g. CN-based approaches, cf. Section 4) rely on LULC classes, rather than indices of vegetation cover. As such, LULC dataset can be an important asset for gully erosion modelling. Furthermore land cover, use and management encompass several other relevant elements that are not necessarily reflected by vegetation indexes. Examples include the shapes and sizes of parcels, parcel boundary characteristics, cropping cycles and tillage practices (e.g. Poesen et al., 2003; Valentin et al., 2005; Piccarreta et al., 2012). Also soil conservation measures often have a significant impact 
Table 4

Overview of global and European digital elevation models and their key characteristics.

\begin{tabular}{|c|c|c|c|c|c|c|c|}
\hline $\begin{array}{l}\text { Dataset/ } \\
\text { product }\end{array}$ & $\begin{array}{l}\text { Spatial } \\
\text { extent }\end{array}$ & $\begin{array}{l}\text { Satellite data } \\
\text { acquisition } \\
\text { period }\end{array}$ & $\begin{array}{l}\text { Satellite sensor, } \\
\text { type of DEM } \\
\text { generation }\end{array}$ & $\begin{array}{l}\text { Pixel } \\
\text { spacing }\end{array}$ & Source & Data download & Reference \\
\hline SRTM-C & $\begin{array}{l}\text { global } \\
\left(60^{\circ} \mathrm{N} \text { to }\right. \\
\left.56^{\circ} \mathrm{S}\right)\end{array}$ & $\begin{array}{l}11-22 \\
\text { February } \\
2000\end{array}$ & $\begin{array}{l}\text { SRTM, single-pass } \\
\text { C-band } \\
\text { interferometry }\end{array}$ & $30 \mathrm{~m}$ & NASA, public & https://earthexplorer.usgs.gov/ & $\begin{array}{l}\text { Rabus et al. } \\
\text { (2003) }\end{array}$ \\
\hline $\begin{array}{l}\text { ASTER } \\
\text { GDEM }\end{array}$ & $\begin{array}{l}\text { global } \\
\left(83^{\circ} \mathrm{N} \text { to }\right. \\
\left.83^{\circ} \mathrm{S}\right)\end{array}$ & 2000 to 2010 & $\begin{array}{l}\text { ASTER, stereo- } \\
\text { correlation of } \\
\text { optical images }\end{array}$ & $30 \mathrm{~m}$ & METI and NASA, public & https://asterweb.jpl.nasa.gov/gdem.asp & $\begin{array}{l}\text { Tachikawa } \\
\text { et al. (2011) }\end{array}$ \\
\hline $\begin{array}{l}\text { ALOS World } \\
\text { 3D } \\
\text { (AW3D5 } \\
\text { and } \\
\text { AW3D30) }\end{array}$ & $\begin{array}{l}\text { global } \\
\left(82^{\circ} \mathrm{N} \text { to }\right. \\
82^{\circ} \mathrm{S} \text {, void- } \\
\text { filled } \\
\text { within } \\
60^{\circ} \mathrm{N} \text { to } \\
\left.60^{\circ} \mathrm{S}\right)\end{array}$ & 2006 to 2011 & $\begin{array}{l}\text { ALOS PRISM, } \\
\text { stereo-correlation } \\
\text { of optical images }\end{array}$ & $\begin{array}{l}5 \mathrm{~m} \text { and } \\
30 \mathrm{~m}\end{array}$ & $\begin{array}{l}\text { JAXA, } 5 \text { m product } \\
\text { commercial, } 30 \text { m product } \\
\text { public }\end{array}$ & $\begin{array}{l}\text { AW3D30 (login required): http://www.eorc. } \\
\text { jaxa.jp/ALOS/en/aw3d30/index.htm }\end{array}$ & $\begin{array}{l}\text { Tadono et al. } \\
\text { (2014); } \\
\text { Takaku et al. } \\
\text { (2014) }\end{array}$ \\
\hline EU-DEM & Europe & 2000 to 2010 & $\begin{array}{l}\text { Hybrid product } \\
\text { based on SRTM and } \\
\text { ASTER GDEM data }\end{array}$ & $25 \mathrm{~m}$ & $\begin{array}{l}\text { European Environment } \\
\text { Agency (EEA) under the } \\
\text { framework of the } \\
\text { Copernicus programme, } \\
\text { public }\end{array}$ & $\begin{array}{l}\text { https://land.copernicus.eu/pan-europe } \\
\text { an/satellite-derived-products/eu-dem }\end{array}$ & $\begin{array}{l}\text { Gonzalez } \\
(2015)\end{array}$ \\
\hline $\begin{array}{l}\text { TanDEM-X } \\
\text { DEM }\end{array}$ & $\begin{array}{l}\text { global } \\
\text { (pole-to- } \\
\text { pole) }\end{array}$ & 2010 to 2015 & $\begin{array}{l}\text { TanDEM-X, bistatic } \\
\text { X-band } \\
\text { interferometric } \\
\text { SAR }\end{array}$ & $\begin{array}{l}12 \mathrm{~m} \\
\text { and } 30 \\
\mathrm{~m}\end{array}$ & $\begin{array}{l}12 \mathrm{~m} \text { commercial product } \\
\text { available from Airbus } \\
\text { Defence and Space as } \\
\text { WorldDEM }^{\mathrm{TM}} ; 12 / 30 \mathrm{~m} \\
\text { products available by } \\
\text { research agreement from } \\
\text { DLR }\end{array}$ & $\begin{array}{l}\text { http://www.intelligence-airbusds. } \\
\text { com/elevation-models/\#worldem; products } \\
\text { available by research agreement from DLR: htt } \\
\text { ps://tandemx-science.dlr.de/ }\end{array}$ & $\begin{array}{l}\text { Krieger et al. } \\
(2007)\end{array}$ \\
\hline
\end{tabular}

on runoff and sediment production (e.g. Maetens et al., 2012a, 2012b). The effects of erosion-preventing or -reducing measures on gully erosion rates and sediment production can be large (for detailed reviews, see Bartley et al., 2020 and Frankl et al., 2021).

Several studies (e.g. Tsendbazar et al., 2015; Grekousis et al., 2015) provide comprehensive comparisons of available regional to global LULC datasets regarding their spatial and temporal resolution, accuracy and thematic coverage. Overall, the opening of the Landsat satellite image archive in 2008 and the launch of the Sentinel-2 satellites at 10 to $20 \mathrm{~m}$ spatial resolution in 2015 and 2017 lay the foundations for a new generation of high resolution global land cover products. The GlobeLand30 dataset was the first open-access global land cover map at $30 \mathrm{~m}$ spatial resolution (Chen et al., 2017). It comprises ten types of land cover for the years 2000 and 2010, extracted from more than 20,000 Landsat and HJ-1 satellite images.

Table 6 lists a selection of global and European LULC datasets. Similar to Table 5 , datasets in this selection are freely available, based on sufficiently long observation periods, relatively recent and/or regularly updated. Overall accuracies of these products vary between 64 and $80 \%$ (Grekousis et al., 2015). Of this selection, CORINE Land Cover provides the longest temporal coverage $(1990,2000,2006,2012,2018)$ and highest classification detail (44 land cover classes) at pan-European scale (Büttner et al., 2014). The S2GLC product based on the analysis of Sentinel-2 imagery currently provides the finest spatial detail at pan-

Table 5

Selection of global vegetation cover datasets (focusing on NDVI and FCover).

\begin{tabular}{|c|c|c|c|c|c|c|c|c|}
\hline Dataset/product & $\begin{array}{l}\text { Spatial } \\
\text { extent }\end{array}$ & Sensor & $\begin{array}{l}\text { Satellite data } \\
\text { acquisition period }\end{array}$ & $\begin{array}{l}\text { Spatial } \\
\text { resolution }\end{array}$ & Temporal resolution & Source & Data download & Reference \\
\hline $\begin{array}{l}\text { Fcover Copernicus } \\
\text { Land } \\
\text { Monitoring }\end{array}$ & $\begin{array}{l}\text { global, } \\
75^{\circ} \mathrm{N} \text { to } \\
60^{\circ} \mathrm{S}\end{array}$ & $\begin{array}{l}\text { Proba V, } \\
\text { SPOT-VGT/ } \\
\text { PROBA V }\end{array}$ & $\begin{array}{l}01 / 2014 \text { to } \\
\text { present, } 1999 \text { to } \\
\text { present }\end{array}$ & $\begin{array}{l}300 \mathrm{~m}, 1 \\
\mathrm{~km}\end{array}$ & 10 days composite & ESA, public & $\begin{array}{l}\text { http://land.copernic } \\
\text { us.eu/global/produc } \\
\text { ts/fcover }\end{array}$ & $\begin{array}{l}\text { Smets et al. } \\
\text { (2017); Smets } \\
\text { et al. (2018) }\end{array}$ \\
\hline MODV1 FCover & global & MODIS & 2000-2016 & $1 \mathrm{~km}$ & monthly composite & ISPRA, public & $\begin{array}{l}\text { Available upon } \\
\text { request from the } \\
\text { author }\end{array}$ & $\begin{array}{l}\text { Filipponi et al. } \\
\text { (2018) }\end{array}$ \\
\hline $\begin{array}{l}\text { MOD44B } \\
\text { Vegetation } \\
\text { Continuous } \\
\text { Fields }\end{array}$ & global & MODIS & 2000 to present & $250 \mathrm{~m}$ & annual composite & NASA, public & $\begin{array}{l}\text { https://lpdaac.usgs. } \\
\text { gov/products/mo } \\
\text { d44bv006/ }\end{array}$ & $\begin{array}{l}\text { Dimiceli et al. } \\
\text { (2015) }\end{array}$ \\
\hline MOD13Q1 NDVI & global & MODIS & 2000 to present & $250 \mathrm{~m}$ & 16-day composite & NASA, public & $\begin{array}{l}\text { https://lpdaac.usgs. } \\
\text { gov/products/mod } \\
\text { 13q1v006/ }\end{array}$ & Didan (2015) \\
\hline $\begin{array}{l}\text { Copernicus Land } \\
\text { Monitoring } \\
\text { NDVI }\end{array}$ & global & $\begin{array}{l}\text { PROBA-V, } \\
\text { SPOT-VGT/ } \\
\text { PROBA-V }\end{array}$ & $\begin{array}{l}02 / 2016 \text { to } \\
\text { present, } 04 / 1998 \\
\text { to present }\end{array}$ & $\begin{array}{l}300 \mathrm{~m}, 1 \\
\mathrm{~km}\end{array}$ & 10 days composite & ESA, public & $\begin{array}{l}\text { http://land.coper } \\
\text { nicus.eu/global/pr } \\
\text { oducts/ndvi }\end{array}$ & $\begin{array}{l}\text { Smets et al. } \\
\text { (2016); Smets } \\
\text { et al. (2018) }\end{array}$ \\
\hline GEE NDVI & global & Landsat & 1984 to present & $30 \mathrm{~m}$ & $\begin{array}{l}\text { 8-day composite, } 32 \text { - } \\
\text { day composite, } \\
\text { annual composite }\end{array}$ & $\begin{array}{l}\text { USGS/Google } \\
\text { Earth Engine, } \\
\text { public }\end{array}$ & $\begin{array}{l}\text { https://earthengine. } \\
\text { google.com/ } \\
\text { datasets/ }\end{array}$ & $\begin{array}{l}\text { Gorelick et al. } \\
\text { (2017) }\end{array}$ \\
\hline WELD NDVI & global & Landsat & 1984-2001 & $30 \mathrm{~m}$ & $\begin{array}{l}\text { monthly composite, } \\
\text { annual composite }\end{array}$ & $\begin{array}{l}\text { USGS/WELD, } \\
\text { public }\end{array}$ & $\begin{array}{l}\text { https://lpdaac.usgs. } \\
\text { gov/products/gwe } \\
\text { ldmov031/ } \\
\text { https://lpdaac.usgs. } \\
\text { gov/products/gwe } \\
\text { ldyrv031/ }\end{array}$ & Roy et al. (2010) \\
\hline
\end{tabular}


European scale with a pixel size of $10 \mathrm{~m}$. It distinguishes 13 land cover classes with an overall accuracy of 83\% (Lewiński et al., 2019).

At global scale, the land cover product recently released by the Copernicus Global Land Service currently overall provides the highest level of detail. Besides a discrete classification with 22 land cover classes, this product contains fraction cover layers for ten base land cover classes (Buchhorn et al., 2019). It is worth mentioning, that the generation of a global land cover product by the ESA WorldCover initiative is in progress, aiming at a $10 \mathrm{~m}$ global land cover map with a minimum of 10 land cover classes and a minimum overall accuracy of $75 \%$ (to be released in 2021).

Yet detailed information on land management practices and the implementation of gully control or other soil and water conservation measures remains largely lacking at (sub)continental scales. We believe this is a highly important research gap. It not only impedes the accurate prediction of gully erosion, but also the evaluation of prevention and mitigation measures at larger scales. Nonetheless, for Europe, several datasets were developed over recent years that can help assessing these aspects. Examples include the Copernicus Pan-European dataset on Small Woody Features (EEA, 2015) and the EU-wide assessments of the Crop Management factor of the Universal Soil Loss equation (EU JRC, 2015; Panagos et al., 2015c). Also estimates of the effect of support practices (i.e. the P-factor in the Universal Soil Loss Equation) have become available at the EU level, based on extensive field surveys (e.g. Panagos et al., 2015e). However, these estimates remain subject to important uncertainties and relate to sheet and rill erosion rather than to gully erosion.

\subsection{Soil properties and lithology}

The formation and expansion of gullies is commonly influenced by particular soil characteristics and behaviour. However, the role of soil properties in explaining patterns of gully erosion remains relatively poorly understood (e.g. Torri and Poesen, 2014; Vanmaercke et al., 2016, 2020). One reason for this is that soil properties affect both the hydrological functioning of soils but also their erosion resistance during concentrated flow shear stresses (e.g. Knapen et al., 2007; cf. Section 4). These effects may counteract each other in ways that currently remain hard to quantify. For example, clayey soils often have high runoff coefficients but can also be very cohesive. Furthermore, accurately quantifying soil properties is generally labour-intensive and therefore remains a big challenge at larger scales. This also impedes our understanding of their influence on gully erosion.

Nonetheless, there are several soil properties that are known to potentially influence gully erosion and are therefore worthwhile considering. Most of these can affect both the erodibility and hydrological functioning of soils. The most relevant properties are likely soil texture characteristics (e.g. percentage of sand, silt and clay), soil organic carbon content, the content and cover of coarse fragments (e.g. Poesen et al., 1999; Torri et al., 1997; Rieke-Zapp et al., 2007; Panagos et al., 2014; Borrelli et al., submitted). Also the water holding capacity, soil depth, bulk density and underlying lithology (or parent material) can play an important role in determining the occurrence and dimensions of gullies (e.g. Kheir et al., 2008; Hopp and McDonnell, 2009). Likewise, the presence of faults and joints can influence gully occurrence, as they are often associated with higher degrees of weathering. Finally, gully occurrence and dynamics can be affected by the presence of specific soil horizons, dispersivity (e.g. sodic properties), susceptibility to soil piping, etc. (e.g. Rienks et al., 2000; Nachtergaele and Poesen, 2002; Bernatek-Jakiel and Poesen, 2018; Bernatek-Jakiel and Wrońska-Wałach, 2018). Many of these properties remain difficult to assess in detail at (sub)continental scales. Nevertheless, qualitative soil maps can be very helpful when aiming to account for such contextspecific aspects.

Table 7 provides an overview of relevant databases at European and global scales. The European Soil Database provides 73 attributes at 1:1 million scale or as a raster format with a $1 \mathrm{~km}$ resolution (Panagos et al., 2012). The dataset is mostly qualitative and mainly based on national soil data and maps from the period 1960-1990. Potentially relevant attributes include: the dominant and secondary parent material, depth

Table 6

Selection of global and European land use/land cover datasets.

\begin{tabular}{|c|c|c|c|c|c|c|c|c|}
\hline $\begin{array}{l}\text { Dataset/product } \\
\text { name }\end{array}$ & $\begin{array}{l}\text { Spatial } \\
\text { coverage }\end{array}$ & $\begin{array}{l}\text { Temporal } \\
\text { coverage }\end{array}$ & Sensor & Spatial resolution & $\begin{array}{l}\text { Classification } \\
\text { scheme/no of } \\
\text { classes }\end{array}$ & Source & Data download & $\begin{array}{l}\text { Reference/ } \\
\text { report }\end{array}$ \\
\hline $\begin{array}{l}\text { MODIS Land } \\
\text { Cover Type/ } \\
\text { MCD12Q1 }\end{array}$ & global & $\begin{array}{l}\text { 2001-2018 } \\
\text { (annual) }\end{array}$ & MODIS & $500 \mathrm{~m}$ & $\begin{array}{l}\text { IGBP scheme, } 17 \\
\text { classes }\end{array}$ & NASA, public & $\begin{array}{l}\text { https://lpdaac. } \\
\text { usgs.gov/produ } \\
\text { cts/mcd12c1v006/ }\end{array}$ & $\begin{array}{l}\text { Friedl et al. } \\
(2010)\end{array}$ \\
\hline GlobCover & & & MERIS & $300 \mathrm{~m}$ & FAO LCCS 22 & ESA, public & http://due.esrin. & Bicheron et al. \\
\hline $\begin{array}{l}\text { GlobCover2005 } \\
\text { GlobCover2009 }\end{array}$ & global & $\begin{array}{l}2004-2006 \\
2009\end{array}$ & & & classes & & $\begin{array}{l}\text { esa.int/page_glob } \\
\text { cover.php }\end{array}$ & $\begin{array}{l}\text { (2008); } \\
\text { Bontemps et al. } \\
\text { (2011) }\end{array}$ \\
\hline $\begin{array}{l}\text { GlobeLand30 } \\
2000\end{array}$ & global & 2000 & $\begin{array}{l}\text { Landsat, HJ- } \\
1\end{array}$ & $30 \mathrm{~m}$ & 10 classes & $\begin{array}{l}\text { UN/National } \\
\text { Geomatics Centre }\end{array}$ & $\begin{array}{l}\text { http://www. } \\
\text { globallandcover. }\end{array}$ & $\begin{array}{l}\text { Chen et al. } \\
\text { (2015); Chen }\end{array}$ \\
\hline 2010 & & 2010 & & & & $\begin{array}{l}\text { of China (NGCC), } \\
\text { public }\end{array}$ & com & et al. (2017) \\
\hline FROM-GLC & global & 2010,2015 & Landsat & $30 \mathrm{~m}$ & 9 classes & $\begin{array}{l}\text { Tsinghua } \\
\text { University, public }\end{array}$ & $\begin{array}{l}\text { http://data.ess. } \\
\text { tsinghua.edu.cn/ }\end{array}$ & $\begin{array}{l}\text { Gong et al. } \\
\text { (2013) }\end{array}$ \\
\hline CCI-LC & global & & MERIS, SPOT & $300 \mathrm{~m}$ & FAO LCCS 22 & ESA, public & http://maps.elie. & ESA (2017) \\
\hline 2000 & & 1998-2002 & VGT & & classes & & ucl.ac.be/CCI/ & \\
\hline 2005 & & 2003-2007 & & & & & viewer/index.php & \\
\hline 2010 & & 2008-2012 & & & & & & \\
\hline $\begin{array}{r}\text { CORINE Land } \\
\text { Cover (CLC) }\end{array}$ & Europe & & $\begin{array}{l}\text { Landsat, } \\
\text { SPOT, IRS, }\end{array}$ & $\begin{array}{l}100 \mathrm{~m} \text { and } 250 \mathrm{~m} \\
\text { (rasterized vector }\end{array}$ & 44 classes & $\begin{array}{l}\text { European } \\
\text { Environment }\end{array}$ & $\begin{array}{l}\text { https://land.coper } \\
\text { nicus.eu/pan-eur }\end{array}$ & $\begin{array}{l}\text { Büttner et al. } \\
\text { (2014) }\end{array}$ \\
\hline CLC1990 & & 1986-1998 & Rapid Eye, & product,minimum & & Agency (EEA), & opean/corine-la & \\
\hline CLC2000 & & 1999-2001 & Sentinel-2 & mapping unit/width & & public & nd-cover & \\
\hline CLC2006 & & 2005-2007 & & $25 \mathrm{ha} / 100 \mathrm{~m})$ & & & & \\
\hline CLC2012 & & 2011-2012 & & & & & & \\
\hline CLC2018 & & 2017-2018 & & & & & & \\
\hline $\begin{array}{l}\text { Land cover } 100 \\
\text { m }\end{array}$ & global & 2015 & PROBA-V & $100 \mathrm{~m}$ & $\begin{array}{l}\text { FAO LCCS } 22 \\
\text { classes }\end{array}$ & ESA, public & $\begin{array}{l}\text { https://land.coper } \\
\text { nicus.eu/global/pr } \\
\text { oducts/lc }\end{array}$ & $\begin{array}{l}\text { Buchhorn et al. } \\
\text { (2019) }\end{array}$ \\
\hline S2GLC & Europe & 2017 & Sentinel-2 & $10 \mathrm{~m}$ & 13 classes & ESA, public & $\begin{array}{l}\text { http://s2glc.cbk. } \\
\text { waw.pl/ }\end{array}$ & $\begin{array}{l}\text { Lewiński et al. } \\
\text { (2019) }\end{array}$ \\
\hline
\end{tabular}


to bedrock, soil structure, soil crusting and water holding capacity. Furthermore, the European Commission amended the LUCAS (Land Use/Cover) surveys of 2009/2012, 2015 and 2018 by including a topsoil survey to collect around 20,000 soil samples from all EU countries (Orgiazzi et al., 2018). The resulting LUCAS topsoil database includes measured data for soil physical and chemical properties. Based on a geostatistical processing of these data, a number of soil property spatial datasets were developed at a $500 \mathrm{~m}$ resolution. These include soil texture (sand, silt, clay), coarse fragment content and available water capacity (Ballabio et al., 2016). Also datasets on chemical properties $(\mathrm{pH}, \mathrm{CEC}, \mathrm{P}, \mathrm{N}, \mathrm{K})$ were also made available at $500 \mathrm{~m}$ resolution for the EU (Ballabio et al., 2019). Likewise, building on the LUCAS database, the EU Joint Research Centre (JRC) developed high resolution soil erodibility datasets (Borrelli et al., 2014; Panagos et al., 2014). The latter are based on physical soil properties, taking into account the impact of stone cover. Other suitable sources for pan-European studies may be the 1:5 million Geological Map of Europe, which includes various lithological and geological attributes (Asch, 2005), or the GeoLiM geo-lithological map for Central Europe (Donnini et al., 2020).

At global scale, the most comprehensive soil property datasets are the Harmonized World Soil Database v 1.2 (FAO/IIASA/ISRIC/ISSCAS/ JRC, 2012) and SoilGrids (Hengl et al., 2017). The first provides a 30 arc-second raster database with over 15,000 different soil mapping units. SoilGrids is a collection of soil properties and classes. It is based on an automated soil mapping procedure using global soil profile data and various (EO) covariates. A ten-fold cross-validation of SoilGrids at $250 \mathrm{~m}$ resolution indicated that the automated algorithms explain $61 \%$ of the overall variation. However, this performance varies strongly depending on the property considered (e.g. $56 \%$ for coarse fragments, $83 \%$ for $\mathrm{pH}$; Hengl et al., 2017). With respect to underlying lithology, the GLiM (Global Lithology Map) by Hartmann and Moosdorf (2012) is currently one of the most detailed globally consistent products.

\subsection{Climate and weather conditions}

Climate and weather conditions, and especially rainfall, are key drivers of gully erosion (cf. Section 4). Rainfall can have short (i.e. triggering) and long term (i.e. conditioning) effects. On the short term, rainfall intensities and amounts are generally key parameters, as they will determine the runoff volume and hence shear stress exerted by the water. Numerous studies have demonstrated significant correlations between rainfall intensity and gully head initiation (e.g. Hayas et al., 2017b), headcut retreat (e.g. Vanmaercke et al., 2016) and gully widening (e.g. Hayas et al., 2019). Conversely, characterizing the effect of rainfall over long periods is more complicate. For example, rainfall controls the soil moisture, which may further condition the runoff response but also the soil resistance against erosion (e.g. Capra et al., 2009). Furthermore, climate over longer timescales can have significant indirect effects, e.g. through its influence on vegetation development and soil mechanical properties (e.g. Dunne et al., 1991; Sanchis et al., 2008; Fan et al., 2017). Complex relations exist among these different effects, making it difficult to define rainfall-related variables that accurately account for all relevant mechanisms. In some contexts, also snowmelt may be a key driver of gully erosion (e.g. Ionita, 2006; Golosov et al., 2018). While snowmelt runoff can already be modelled and monitored to some extent, its effects on gully erosion remain relatively understudied, especially at (sub)continental scales (e.g. Maltsev and Yermolaev, 2019).

Hence, the type and spatio-temporal resolution of precipitation data required will vary depending on the study region, but also in function of the purpose. Modelling exercises at short time scales (e.g. daily, eventbased) require data of similar temporal resolutions. When aiming to understand mean tendencies and spatial variations, coarser data are already useful. For example, long-term average proxies like the rainy day normal can already serve as a useful predictor for average trends (e. g. Vanmaercke et al., 2016; Hayas et al., 2017b).

Table 8 provides a selection of available global and European rainfall datasets, building on an earlier overview presented by Sun et al. (2018). These gridded datasets are based on a variety of methods. Several are derived from rain gauge data, using different regionalization methods (e.g. Rudolf et al., 2009; Schamm et al., 2014). The accuracy of such datasets can be expected to depend on the gauge network density which

Table 7

Selection of global and European soil and geological/lithological datasets.

\begin{tabular}{|c|c|c|c|c|c|c|}
\hline Dataset/product name & Spatial extent & $\begin{array}{l}\text { Data } \\
\text { acquisition } \\
\text { period }\end{array}$ & $\begin{array}{l}\text { Spatial } \\
\text { resolution }\end{array}$ & Source & Data download & Reference \\
\hline $\begin{array}{l}\text { Harmonized world soil } \\
\text { database v1.2 }\end{array}$ & $\begin{array}{l}\text { global, } \\
\text { continental, } \\
\text { regional }\end{array}$ & 1971-2012 & 30 arc sec & $\begin{array}{l}\text { FAO/UNESCO, } \\
\text { public }\end{array}$ & $\begin{array}{l}\text { http://www.fao.org/soils-portal/soil-survey/soil- } \\
\text { maps-and-databases/harmonized-world-soil-d } \\
\text { atabase-v12/en/ }\end{array}$ & $\begin{array}{l}\text { FAO/IIASA/ } \\
\text { ISRIC/ISSCAS/ } \\
\text { JRC (2012) }\end{array}$ \\
\hline $\begin{array}{l}\text { LUCAS } 2009 \text { Topsoil } \\
\text { physical properties } \\
\text { for Europe }\end{array}$ & Europe & 2009 & $500 \mathrm{~m}$ & $\begin{array}{l}\text { European } \\
\text { Commission/JRC, } \\
\text { public }\end{array}$ & $\begin{array}{l}\text { https://esdac.jrc.ec.europa.eu/content/topsoil-ph } \\
\text { ysical-properties-europe-based-lucas-topsoil-data }\end{array}$ & $\begin{array}{l}\text { Ballabio et al. } \\
(2016)\end{array}$ \\
\hline $\begin{array}{l}\text { LUCAS } 2009 \text { Chemical } \\
\text { properties }\end{array}$ & Europe & 2009 & $500 \mathrm{~m}$ & $\begin{array}{l}\text { European } \\
\text { Commission/JRC, } \\
\text { public }\end{array}$ & $\begin{array}{l}\text { https://esdac.jrc.ec.europa.eu/content/che } \\
\text { mical-properties-european-scale-based-lucas-tops } \\
\text { oil-data }\end{array}$ & $\begin{array}{l}\text { Ballabio et al. } \\
\text { (2019) }\end{array}$ \\
\hline SoilGrids & global & $2013-2017$ & $250-1000 \mathrm{~m}$ & ISRIC, public & https://soilgrids.org/ & $\begin{array}{l}\text { Ribeiro et al. } \\
\text { (2015); Hengl } \\
\text { et al. (2017) }\end{array}$ \\
\hline $\begin{array}{l}\text { European Soil } \\
\text { Database }\end{array}$ & $\begin{array}{l}\text { Europe (and } \\
\text { Eurasia) }\end{array}$ & 1960-1990 & $1 \mathrm{~km}$ & $\begin{array}{l}\text { European } \\
\text { Commission/JRC, } \\
\text { public }\end{array}$ & $\begin{array}{l}\text { https://esdac.jrc.ec.europa.eu/content/eur } \\
\text { opean-soil-database-v2-raster-library-1kmx1km }\end{array}$ & $\begin{array}{l}\text { Panagos et al. } \\
(2012)\end{array}$ \\
\hline Soil erodibility dataset & Europe & 2014 & $500 \mathrm{~m}$ & $\begin{array}{l}\text { European } \\
\text { Commission/JRC, } \\
\text { public }\end{array}$ & $\begin{array}{l}\text { https://esdac.jrc.ec.europa.eu/content/soil-er } \\
\text { odibility-k-factor-high-resolution-dataset-europe }\end{array}$ & $\begin{array}{l}\text { Panagos et al. } \\
(2014)\end{array}$ \\
\hline $\begin{array}{l}\text { 1: } 5 \text { million Geological } \\
\text { Map of Europe } \\
\text { (IGME 5000) }\end{array}$ & $\begin{array}{l}\text { Europe and } \\
\text { adjacent areas }\end{array}$ & 1990-2000 & 1: 5million & $\begin{array}{l}\text { BGR, national } \\
\text { geological surveys, } \\
\text { public }\end{array}$ & $\begin{array}{l}\text { https://www.bgr.bund.de/EN/Themen/Sammlun } \\
\text { gen-Grundlagen/GG_geol_Info/Karten/Internat } \\
\text { ional/Europa/IGME5000/IGME_Project/IGME_Pr } \\
\text { ojectinfo.html }\end{array}$ & Asch (2005) \\
\hline $\begin{array}{l}\text { Geo-lithological map } \\
\text { for Central Europe } \\
\text { (Geo-LiM) }\end{array}$ & Central Europe & 1990-2010 & 1:1 million & CNR IRPI, public & https://zenodo.org/record/3530257 & $\begin{array}{l}\text { Donnini et al. } \\
\text { (2020) }\end{array}$ \\
\hline Global Lithology Map & global & unknown & $\begin{array}{l}\text { 1: } 3750000 \\
\text { (average) }\end{array}$ & $\begin{array}{l}\text { University of } \\
\text { Hamburg, (partly) } \\
\text { public }\end{array}$ & $\begin{array}{l}\text { https://doi.pangaea.de/10.1594/PANGAEA. } \\
788537\end{array}$ & $\begin{array}{l}\text { Hartmann and } \\
\text { Moosdorf (2012) }\end{array}$ \\
\hline
\end{tabular}


may be limited, especially in Global South countries (e.g. Schneider et al., 2014). Despite their generally shorter time series, RADAR-derived products can provide an important alternative (e.g. Ashouri et al., 2015). RADAR-based rainfall observation networks are implemented in many countries. They measure rainfall rates, based on the analysis of the echoes generated by the interaction between active microwave signals and rain drops (Sauvageot, 1994; Wexler and Atlas, 1963). RADAR rainfall estimates are indirect and represent measures of rainfall far from the surface, which may be a limitation. However, their high spatiotemporal level of detail (e.g. estimates every $10 \mathrm{~min}$ at a $5 \times 5 \mathrm{~km}$ resolution) allows measuring local, short and intense rainfall events. Overall, data from regional RADAR networks (and in particular historical RADAR data series) remain scarcely accessible and underused. Other gridded rainfall products are derived from satellite observations. In general, they are based on algorithms that combine passive microwave and infrared measurements from geostationary and low earth orbit satellites. Despite their often limited spatio-temporal resolutions, their main advantages are their global coverage and their easy accessibility. Hence, they offer great potential for gully erosion modelling at larger scales, especially in countries where other rainfall data are scarce. Nonetheless, also these satellite products generally rely to some extent on gauging station observations and can be subject to uncertainties (e.g. Monsieurs et al., 2018). Finally, several datasets have been produced through reanalysis, in which meteorological modelling results are combined with rainfall observations (Gelaro et al., 2017). These products have diverse spatial and temporal resolutions that cover extended periods (Table 8).

At European scale, another relevant proxy worth mentioning is the rainfall erosivity dataset, which was produced with 30-min precipitation data from 1675 stations in the EU (Panagos et al., 2015d). While this proxy was originally developed for simulating sheet and rill erosion rates, it may also be useful for gully erosion modelling.

\section{Policies relevant to gully erosion: frameworks and current needs}

At the global level, the issue of soil erosion receives significant attention (e.g. Montanarella et al., 2016). For example, the United Nations Convention to Combat Desertification (UNCCD, 2018) and the Intergovernmental Science-Policy Platform on Biodiversity and Ecosystem Services (IPBES; Scholes et al., 2018) both stress the importance of human-induced soil erosion as a key driver of land degradation and expresses concerns about the potential impacts of climate change on soil erosion rates. Also several of the UN Sustainable Development Goals (SDGs) clearly identify soil resources as being of crucial importance. More specifically, Goal 1 (No Poverty), Goal 2 (Zero Hunger), Goal 3 (Good Health and Well-being), Goal 6 (Clean Water and Sanitation), Goal 13 (Climate Action) and Goal 15 (Life on Land) strongly link to the need to preserve soil resources in order to achieve these goals by 2030 (Keesstra et al., 2016; Bouma, 2019; Panagos and Katsoyiannis, 2019; Albaladejo et al., 2021). The Food Agriculture Organization has published Guidelines for Sustainable Soil Management (FAO, 2016), aiming to support countries in implementing actions for soil protection.

The European Union is a front-runner in attaining the SDGs and has committed to play an active role towards their realization. With respect to SDG 15 'Life on Land', the EU identifies 3 sub-themes: ecosystem status, biodiversity and land degradation (Panagos and Katsoyiannis, 2019). One of the indicators used to assess progress with respect to land degradation is soil erosion by water (Panagos et al., 2015a, 2015b). Overall, soil protection is not subject to a single, coherent legislation within the EU. Although a Soil (Thematic Strategy (COM 2006.231), 2006) was proposed, the Commission withdrew this proposal to develop a Soil Framework Directive in 2014. Nevertheless, there is a strong commitment of the EU and its member states to conserve soil resources and several measures exist across different policies.

In the EU agricultural sector, the main active policy instrument to promote agro-environmental friendly agriculture is the Cross Compliance mechanism, which was introduced in the Common Agricultural Policy (CAP) in 2003. In 2009, the standards of Good Agricultural and Environmental Conditions (GAEC) were introduced in the CAP legislation framework (Common Agricultural Policy (CAP), 73/2009, 2020). One of the requirements in the GAEC is to limit soil loss by water erosion and to maintain soil organic carbon (Borrelli et al., 2016). For this, the GAEC standards include a set of practices, such as reduced tillage, crop residues management, cover crops, maintaining terraces, grass margins next to watercourses, contour farming and crop rotation. While most of these practices may have a beneficial effect on preventing gully erosion, the GAEC makes no explicit reference to the mitigation of existing permanent gullies, nor to the management of ephemeral gullies. Nonetheless, specific measures can be taken by individual member states to tackle (gully) erosion, using funds from the European Agricultural Fund for Rural Development (EAFRD), under the Council Regulation EU $1305 / 2013$. For example, in the Spanish region of Andalucia, gully control measures were subsidized under this programme in 2009-2010. However, despite some initial successes, this programme was discontinued because of a shift in regional priorities. In Flanders (Belgium) municipalities can request subsidies for developing local erosion control plans and implementing small-scale erosion control measures like check dams or sediment control basins.

Also the new legislative proposal of the European Commission for the post-2020 Common Agricultural Policy (CAP) 2021-27, COM (2018) 392 (2018) includes measures for soil conservation (e.g. cover crops) and maintaining soil organic carbon. Post-2020, soil protection will gain more importance through Eco-schemes as an integral part of the new Green Architecture design. In fact, effective soil management is one of the nine key objectives of the new CAP. While the post-2020 CAP is still being defined and will likely only come into force in 2023, it is clear that Member States will have greater flexibility in deciding on policy measures through the CAP national strategic plans. This may create opportunities to target gully erosion more specifically and to tailor the implementation of measures to particular farming contexts. However, apart from agriculture, also land use changes such as reforestation can have significant impacts on gully erosion. Presently, the European Union does not have a common forestry policy making it still primarily a national matter. Nonetheless, the CAP is the main funding source for forestry, with conversions of agricultural land to forest being supported by Rural Development funds.

In the area of European water policy, the Water Framework Directive (WFD, Directive 2000/60/EC, 2020) and the Nitrate Directive (91/676/ EEC), 1991 set environmental targets that promote soil conservation actions. Under the WFD, EU Member States need to establish Programmes of Measures (PoMs) to achieve good ecological and chemical statuses of water bodies. Diffuse pollution from soil erosion in cropland is identified as a key pressure on water quality in many River Basin Management Plans across the EU (e.g. Heininger et al., 2015), thus erosion control measures should be adopted in PoMs to curb agricultural impacts on water bodies. Similarly, the Nitrate Directive requires implementation of good agricultural practices in nitrate vulnerable zones to reduce runoff, erosion, and nitrate losses. However, the WFD and the Nitrate Directive do not mention soil (or gully) erosion and its control explicitely.

Recently, the European Commission introduced the European Green Deal EU COM(2019) 640 (2019) with the ambition to make EU the first climate-neutral continent by 2050 . The EU Green Deal sets ambitious targets such as protecting $30 \%$ of the EU's land area, bringing back at least $10 \%$ of the agricultural area under high-diversity landscape features and plant more than three billion trees by 2030 (Montanarella and Panagos, 2021). Although those targets have not yet been translated in specific policy measures, it is clear that implementing the EU Green Deal will contribute to sustainable soil management, introducing more soil conservation measures, reducing land degradation and mitigating soil losses due to erosion. 
Table 8

Selection of global and European rainfall datasets (based on Sun et al., 2018).

\begin{tabular}{|c|c|c|c|c|c|c|c|c|}
\hline $\begin{array}{l}\text { Dataset/ } \\
\text { product }\end{array}$ & $\begin{array}{l}\text { Spatial } \\
\text { coverage }\end{array}$ & $\begin{array}{l}\text { Spatial } \\
\text { resolution }\end{array}$ & $\begin{array}{l}\text { Temporal } \\
\text { resolution }\end{array}$ & Period & $\begin{array}{l}\text { Sensor and } \\
\text { type of } \\
\text { retrieval }\end{array}$ & Source & Data download & Reference \\
\hline$E$-OBS & Europe & $\begin{array}{l}0.55^{\circ} / \\
0.50^{\circ} / \\
0.22^{\circ} \\
\text { rotated/ } \\
0.44^{\circ} \text { rot }\end{array}$ & Daily & 1950-present & $\begin{array}{l}\text { Gridded } \\
\text { rain gauge }\end{array}$ & ECA\&D & $\begin{array}{l}\text { https://www.ecad. } \\
\text { eu/download/ensembles/download. } \\
\text { php\#datafiles }\end{array}$ & $\begin{array}{l}\text { Haylock } \\
\text { et al. (2008); } \\
\text { Cornes et al. } \\
\text { (2018) }\end{array}$ \\
\hline CRU & Global land & $0.5^{\circ} \times 0.5^{\circ}$ & Monthly & 1901-2016 & $\begin{array}{l}\text { Gridded } \\
\text { rain gauge }\end{array}$ & $\begin{array}{l}\text { CRU of the } \\
\text { University of East } \\
\text { Anglia }\end{array}$ & http://www.cru.uea.ac.uk/data & $\begin{array}{l}\text { Harris et al. } \\
\text { (2014); New } \\
\text { et al. (2000) }\end{array}$ \\
\hline GHCN-M & Global land & $5^{\circ} \times 5^{\circ}$ & Monthly & 1900-present & $\begin{array}{l}\text { Gridded } \\
\text { rain gauge }\end{array}$ & $\begin{array}{l}\text { National Climatic } \\
\text { Data Center }\end{array}$ & $\begin{array}{l}\text { https://www.ncdc.noaa.gov/ghc } \\
\text { nm/v2.php }\end{array}$ & $\begin{array}{l}\text { Peterson and } \\
\text { Vose (1997) }\end{array}$ \\
\hline GPCC-monthly & Global land & $\begin{array}{l}0.25^{\circ} \times \\
0.25^{\circ} \\
0.5^{\circ} \times \\
0.5^{\circ}, 1.0^{\circ} \\
\times 1.0^{\circ} \\
2.5^{\circ} \times 2.5^{\circ}\end{array}$ & Monthly & 1891-2016 & $\begin{array}{l}\text { Gridded } \\
\text { rain gauge }\end{array}$ & $\begin{array}{l}\text { Global Precipitation } \\
\text { Climatology Centre }\end{array}$ & $\begin{array}{l}\text { https://opendata.dwd.de/climate_env } \\
\text { ironment/GPCC/html/fulldata-month } \\
\text { ly_v2018_doi_download.html }\end{array}$ & $\begin{array}{l}\text { Schneider } \\
\text { et al. (2014) }\end{array}$ \\
\hline GPCC-daily & Global land & $1.0^{\circ} \times 1.0^{\circ}$ & Daily & 1982-2013 & $\begin{array}{l}\text { Gridded } \\
\text { rain gauge }\end{array}$ & $\begin{array}{l}\text { Global Precipitation } \\
\text { Climatology Centre }\end{array}$ & $\begin{array}{l}\text { https://opendata.dwd.de/climate_en } \\
\text { vironment/GPCC/html/fulldata-dail } \\
\text { y_v2018_doi_download.html }\end{array}$ & $\begin{array}{l}\text { Schamm } \\
\text { et al. (2014) }\end{array}$ \\
\hline PREC/L & Global land & $\begin{array}{l}0.5^{\circ} \times \\
0.5^{\circ}, 1.0^{\circ} \\
\times 1.0^{\circ} \\
2.5^{\circ} \times 2.5^{\circ}\end{array}$ & Monthly & $1948-2020$ & $\begin{array}{l}\text { Gridded } \\
\text { rain gauge }\end{array}$ & NCEP/NOAA & $\begin{array}{l}\text { https://www.esrl.noaa.gov/psd } \\
\text { /data/gridded/data.precl.html }\end{array}$ & $\begin{array}{l}\text { Chen et al. } \\
\text { (2002) }\end{array}$ \\
\hline UDEL & Global land & $0.5^{\circ} \times 0.5^{\circ}$ & Monthly & 1900-2017 & $\begin{array}{l}\text { Gridded } \\
\text { rain gauge }\end{array}$ & $\begin{array}{l}\text { University of } \\
\text { Delaware }\end{array}$ & $\begin{array}{l}\text { https://www.esrl.noaa.gov/psd/data/ } \\
\text { gridded/data.UDel_AirT_Precip.html }\end{array}$ & $\begin{array}{l}\text { Willmott } \\
\text { and } \\
\text { Matsuura } \\
\text { (1995) }\end{array}$ \\
\hline СPC & Global land & $0.5^{\circ} \times 0.5^{\circ}$ & Daily & 1979-present & $\begin{array}{l}\text { Gridded } \\
\text { rain gauge }\end{array}$ & $\mathrm{CPC}$ & $\begin{array}{l}\text { https://www.esrl.noaa.gov/psd/data/ } \\
\text { gridded/data.cpc.globalprecip.html }\end{array}$ & $\begin{array}{l}\text { Xie et al. } \\
(2010)\end{array}$ \\
\hline GPCP & Global & $2.5^{\circ}$ & Monthly & 1979-present & $\begin{array}{l}\text { Satellite }+ \\
\text { rain gauge }\end{array}$ & $\begin{array}{l}\text { NOAA/OAR/ESRL } \\
\text { PSD }\end{array}$ & $\begin{array}{l}\text { https://www.esrl.noaa.gov/psd/data/ } \\
\text { gridded/data.gpcp.html }\end{array}$ & $\begin{array}{l}\text { Adler et al. } \\
(2003)\end{array}$ \\
\hline GPCP 1dd & Global & $1.0^{\circ}$ & Daily & 1996-present & $\begin{array}{l}\text { Satellite }+ \\
\text { rain gauge }\end{array}$ & NASA & $\begin{array}{l}\text { https://rda.ucar.edu/datasets/ds } \\
728.3 /\end{array}$ & $\begin{array}{l}\text { Huffman } \\
\text { and Bolvin } \\
(2013)\end{array}$ \\
\hline GPCP_PEN_v2.2 & Global & $2.5^{\circ}$ & Pentad & 1979-present & $\begin{array}{l}\text { Satellite }+ \\
\text { rain gauge }\end{array}$ & NASA & $\begin{array}{l}\text { https://data.nodc.noaa.gov/cgi-bin/i } \\
\text { so?id=gov.noaa.ncdc:C00933 }\end{array}$ & $\begin{array}{l}\text { Xie et al. } \\
(2003 \text {, } \\
2011)\end{array}$ \\
\hline CMAP & Global & $2.5^{\circ}$ & $\begin{array}{l}\text { Monthly, } \\
\text { Pentad }\end{array}$ & $\begin{array}{l}\text { 1979-2016, } \\
\text { 1979-present }\end{array}$ & $\begin{array}{l}\text { Satellite }+ \\
\text { rain gauge }\end{array}$ & NCEP-NCAR & $\begin{array}{l}\text { https://www.esrl.noaa.gov/psd/data/ } \\
\text { gridded/data.cmap.html }\end{array}$ & $\begin{array}{l}\text { Xie et al. } \\
\text { (2003); Xie } \\
\text { and Arkin } \\
\text { (1997) }\end{array}$ \\
\hline TRMM 3B43 & $\begin{array}{l}\text { Global } \\
\left(50^{\circ} \mathrm{S}-50^{\circ} \mathrm{N}\right)\end{array}$ & $0.25^{\circ}$ & 3 h/Daily & 1998-present & Satellite & NASA & $\begin{array}{l}\text { https://pmm.nasa.gov/data-access/ } \\
\text { downloads/trmm }\end{array}$ & $\begin{array}{l}\text { Huffman } \\
\text { et al. (2007) }\end{array}$ \\
\hline GSMaP & $\begin{array}{l}\text { Global } \\
\left(60^{\circ} \mathrm{S}-60^{\circ} \mathrm{N}\right)\end{array}$ & $0.1^{\circ}$ & $1 \mathrm{~h} /$ daily & $2000-2014$ & Satellite & JAXA & $\begin{array}{l}\text { http://sharaku.eorc.jaxa.jp/GSMaP_cr } \\
\text { est/ }\end{array}$ & $\begin{array}{l}\text { Ushio et al. } \\
\text { (2009) }\end{array}$ \\
\hline PERSIANN-CCS & $\begin{array}{l}\text { Global } \\
\left(60^{\circ} \mathrm{S}-60^{\circ} \mathrm{N}\right)\end{array}$ & $0.04^{\circ}$ & $\begin{array}{l}30 \mathrm{~min} / 3 \\
6\end{array}$ & 2003-present & Satellite & $\begin{array}{l}\text { Center for } \\
\text { Hydrometeorology } \\
\text { and Remote Sensing } \\
\text { (CHRS) at the } \\
\text { University of } \\
\text { California }\end{array}$ & http://chrsdata.eng.uci.edu/ & $\begin{array}{l}\text { Sorooshian } \\
\text { et al. (2000); } \\
\text { Nguyen } \\
\text { et al. (2019) }\end{array}$ \\
\hline $\begin{array}{l}\text { PERSIANN- } \\
\text { CDR }\end{array}$ & $\begin{array}{l}\text { Global } \\
\left(60^{\circ} \mathrm{S}-60^{\circ} \mathrm{N}\right)\end{array}$ & $0.25^{\circ}$ & $\begin{array}{l}\text { Daily/ } \\
\text { monthly/ } \\
\text { yearly }\end{array}$ & 1983-present & $\begin{array}{l}\text { Satellite }+ \\
\text { rain gauge }\end{array}$ & $\begin{array}{l}\text { Center for } \\
\text { Hydrometeorology } \\
\text { and Remote Sensing } \\
\text { (CHRS) at the } \\
\text { University of } \\
\text { California }\end{array}$ & http://chrsdata.eng.uci.edu/ & $\begin{array}{l}\text { Ashouri } \\
\text { et al. (2015); } \\
\text { Nguyen } \\
\text { et al. (2019) }\end{array}$ \\
\hline CMORPH & $\begin{array}{l}\text { Global } \\
\left(60^{\circ} \mathrm{S}-60^{\circ} \mathrm{N}\right)\end{array}$ & $0.25^{\circ}$ & $\begin{array}{l}30 \mathrm{~min} / 3 \\
\mathrm{~h} / \text { daily }\end{array}$ & $2002-2017$ & Satellite & $\begin{array}{l}\text { Climate Prediction } \\
\text { Center }\end{array}$ & $\begin{array}{l}\text { https://climatedataguide.ucar.edu } \\
\text { /climate-data/cmorph-cpc-morphin } \\
\text { g-technique-high-resolution-precipitat } \\
\text { ion-60s-60n }\end{array}$ & $\begin{array}{l}\text { Joyce et al. } \\
\text { (2004) }\end{array}$ \\
\hline GPM & $\begin{array}{l}\text { Global } \\
\left(60^{\circ} \mathrm{S}-60^{\circ} \mathrm{N}\right)\end{array}$ & $0.1^{\circ}$ & $\begin{array}{l}30 \mathrm{~min} / 3 \\
\mathrm{~h} / \text { daily }\end{array}$ & 2000-present & Satellite & NASA & $\begin{array}{l}\text { https://pmm.nasa.gov/data-access/ } \\
\text { downloads/gpm }\end{array}$ & $\begin{array}{l}\text { Hou et al. } \\
\text { (2008); Hou } \\
\text { et al. (2014); } \\
\text { Huffman } \\
\text { et al. (2015) }\end{array}$ \\
\hline MSWEP & Global & $0.1^{\circ} / 0.5^{\circ}$ & 3 h/daily & 1979-present & $\begin{array}{l}\text { Satellite }+ \\
\text { rain gauge }\end{array}$ & Princeton University & http://www.gloh2o.org/ & $\begin{array}{l}\text { Beck et al. } \\
\text { (2017) }\end{array}$ \\
\hline NCEP1 & Global & $2.5^{\circ} \times 2.5$ & $\begin{array}{l}\text { Monthly/ } \\
\text { Daily/6 } \\
\text { hourly }\end{array}$ & 1948-present & Reanalysis & NCEP/NCAR & $\begin{array}{l}\text { https://www.esrl.noaa.gov/psd/data/ } \\
\text { gridded/data.ncep.reanalysis.surface. } \\
\text { html }\end{array}$ & $\begin{array}{l}\text { Kalnay et al. } \\
\text { (1996) }\end{array}$ \\
\hline NCEP2 & Global & $2.5^{\circ} \times 2.5^{\circ}$ & & 1979-present & Reanalysis & NCEP/NCAR & & \\
\hline
\end{tabular}


Table 8 (continued)

\begin{tabular}{|c|c|c|c|c|c|c|c|c|}
\hline $\begin{array}{l}\text { Dataset/ } \\
\text { product }\end{array}$ & $\begin{array}{l}\text { Spatial } \\
\text { coverage }\end{array}$ & $\begin{array}{l}\text { Spatial } \\
\text { resolution }\end{array}$ & $\begin{array}{l}\text { Temporal } \\
\text { resolution }\end{array}$ & Period & $\begin{array}{l}\text { Sensor and } \\
\text { type of } \\
\text { retrieval }\end{array}$ & Source & Data download & Reference \\
\hline & & & $\begin{array}{l}\text { Monthly/ } \\
6 \text { hourly }\end{array}$ & & & & $\begin{array}{l}\text { https://www.esrl.noaa.gov/psd/data/ } \\
\text { gridded/data.ncep.reanalysis2.surface. } \\
\text { html }\end{array}$ & $\begin{array}{l}\text { Kanamitsu } \\
\text { et al. (2002) }\end{array}$ \\
\hline ERA 40 & Global & $\begin{array}{l}2.5^{\circ} \times \\
2.5^{\circ} / \\
1.125^{\circ} \times \\
1.125^{\circ}\end{array}$ & $\begin{array}{l}\text { Monthly/ } \\
6 \text { hourly }\end{array}$ & 1957-2002 & Reanalysis & ECMWF & $\begin{array}{l}\text { http://apps.ecmwf.int/datasets/da } \\
\text { ta/era40-daily/levtype=sfc/ }\end{array}$ & $\begin{array}{l}\text { Uppala et al. } \\
\text { (2005) }\end{array}$ \\
\hline ERA Interim & Global & $\begin{array}{l}1.5^{\circ} \times \\
1.5^{\circ} / \\
0.75^{\circ} \times \\
0.75^{\circ}\end{array}$ & $\begin{array}{l}\text { Monthly/ } \\
6 \text { hourly }\end{array}$ & 1979-present & Reanalysis & ECMWF & $\begin{array}{l}\text { http://apps.ecmwf.int/datasets/data/ } \\
\text { interim-full-daily/levtype }=\text { sfc/ }\end{array}$ & $\begin{array}{l}\text { Dee et al. } \\
(2011)\end{array}$ \\
\hline 20CRv2 & Global & $2.0^{\circ} \times 2.0^{\circ}$ & $\begin{array}{l}\text { Dailyaily/ } \\
6 \text { hourly }\end{array}$ & $1851-2014$ & Reanalysis & NOAA & $\begin{array}{l}\text { https://www.esrl.noaa.gov/psd/dat } \\
\text { a/gridded/data.20thC_ReanV2c.press } \\
\text { ure.html }\end{array}$ & $\begin{array}{l}\text { Compo et al. } \\
\text { (2011) }\end{array}$ \\
\hline JRA-55 & Global & $60 \mathrm{~km}$ & $\begin{array}{l}\text { Monthly/ } \\
3 \text { hourly/6 } \\
\text { hourly }\end{array}$ & 1958-present & Reanalysis & $\begin{array}{l}\text { Japanese } \\
\text { Meteorological } \\
\text { Agency }\end{array}$ & $\begin{array}{l}\text { http://jra.kishou.go.jp/JRA-55/inde } \\
\text { x_en.html }\end{array}$ & $\begin{array}{l}\text { Ebita et al. } \\
(2011)\end{array}$ \\
\hline MERRA & Global & $\begin{array}{l}0.5^{\circ} \times \\
0.67^{\circ}\end{array}$ & Daily & 1979-present & Reanalysis & NASA & $\begin{array}{l}\text { https://gmao.gsfc.nasa.gov/reanalysis } \\
\text { /MERRA/ }\end{array}$ & $\begin{array}{l}\text { Rienecker } \\
\text { et al. (2011) }\end{array}$ \\
\hline MERRA Land & Global & $\begin{array}{l}0.5^{\circ} \times \\
0.67^{\circ}\end{array}$ & $\begin{array}{l}\text { Monthly/ } \\
\text { Daily/ } \\
\text { 1hourly }\end{array}$ & 1980-present & Reanalysis & NASA & $\begin{array}{l}\text { https://gmao.gsfc.nasa.gov/reana } \\
\text { lysis/MERRA-Land/ }\end{array}$ & $\begin{array}{l}\text { Reichle et al. } \\
\text { (2011) }\end{array}$ \\
\hline MERRA2 & Global & $\begin{array}{l}0.5^{\circ} \times \\
0.67^{\circ}\end{array}$ & Daily & 1980-present & Reanalysis & NASA & $\begin{array}{l}\text { https://gmao.gsfc.nasa.gov/reanalys } \\
\text { is/MERRA-2/ }\end{array}$ & $\begin{array}{l}\text { Gelaro et al. } \\
\text { (2017) }\end{array}$ \\
\hline CFSR 38 & Global & $38 \mathrm{~km}$ & hourly & 1979-2011 & Reanalysis & NOAA & $\begin{array}{l}\text { https://www.ngdc.noaa.gov/metavie } \\
\text { w/page?xml=NOAA/NESDIS/NCDC/ } \\
\text { Geoportal/iso/xml/C00765.xml\&vie } \\
\text { w=getDataView\&header }=\text { none }\end{array}$ & $\begin{array}{l}\text { Saha et al. } \\
(2010)\end{array}$ \\
\hline MSG CPP & Europe & $3 \times 3 \mathrm{~km}$ & $15 \mathrm{~min}$ & 2005-2011 & Satellite & $\begin{array}{l}\text { Koninklijk } \\
\text { Nederlands } \\
\text { Meteorologisch } \\
\text { Instituut (KNMI) }\end{array}$ & $\begin{array}{l}\text { http://msgcpp.knmi.nl/mediawiki/in } \\
\text { dex.php/MSG_Cloud_Physical_Proper } \\
\text { ties_\%28CPP\%29 }\end{array}$ & $\begin{array}{l}\text { Roebeling } \\
\text { et al. (2008) }\end{array}$ \\
\hline
\end{tabular}

In practice, a wide range of gully control practices exists and have been implemented in numerous areas (e.g. Evrard et al., 2008; Castillo and Gómez, 2016; Fig. 4). The overall effectiveness of such measures has been recently reviewed (e.g. Bartley et al., 2020; Frankl et al., 2021). The most common conservation practices include increasing the soil erosion resistance in concentrated flow zones, protecting the headcut, diverting overland flows away from gullies as well as creating terraces, grassed waterways, check dams and water and sediment control basins (Casalı et al., 1999; Poesen et al., 2003; Valentin et al., 2005). Also in the EU, such measures have been implemented. Nevertheless, measures that directly address gully erosion are not yet compulsory in EU policies. Also soil conservation measures such as reduced tillage are applied at a more limited scale in the EU (4\% no till and 22\% reduced tillage; EU Agricultural Census, 2010; Panagos et al., 2015b) as compared to for example the USA (35\% no till and $27 \%$ reduced tillage; Census of Agriculture, 2012). In terms of land management, this makes European arable land potentially more vulnerable to ephemeral gully erosion. Overall, soil erosion is clearly considered an important agroenvironmental indicator to assess the effectiveness of EU policies such as the Common Agricultural Policy (e.g. Gobin et al., 2004; Zalidis et al., 2004). However, the CAP-induced soil conservation practices consider only sheet and rill erosion and do not account for gully erosion (Panagos et al., 2015a, 2015b).

The situation in the EU contrasts, with other regions. For example in the United States, gully control measures are more widespread. Measures to reduce gully erosion have been implemented as early as the 1930s in the USA, including those by the Civilian Conservation Corps (USDA, 2007). The development of handbooks on the formation and control of gullies by national agencies greatly contributed to this (e.g. USDA, 2007). Grade stabilization structures such as drop pipes were the most common conservation practice to control gully erosion (Wilson et al., 2008), but also extensive reforestation and reservoir construction programmes were implemented (e.g. Rhemtulla et al., 2009; Abbasi et al., 2019). In China, The Grain for Green programme strongly mitigated gully erosion in the Loess Plateau by implementing slope conservation measures and check-dams on a massive scale (Xiang-zhou et al., 2004; Sun et al., 2019). In some areas, the restoration of vegetation on hillslopes through the Grain for Green programme reduced gully erosion rates with up to $90 \%$ (Wang et al., 2016). Also in Australia, there are several large government-funded programmes focused on gully remediation (Wilkinson et al., 2019). They aim to reduce sediment and particulate nutrient loads that form, in combination with climate change, an important threat to the Great Barrier Reef (MacNeil et al., 2019). A variety of gully remediation approaches are currently tested in catchments draining to the Great Barrier Reef, ranging from low-cost erosion control structures to larger scale landscape remediation (Koci et al., 2021). Also Ethiopia has implemented several large-scale soil and water conservation programmes that included measures specifically targetting gully erosion (e.g. Haregeweyn et al., 2015).

In summary, the large number of policy initiatives at the European level (i.e. the Soil Thematic Strategy, the Common Agricultural Policy, the Water Framework Directive, and EU Green Deal) as well as global initiatives (Sustainable Development Goals, FAO guidelines, IPBES, UNCCD) show that soil erosion is widely recognized as a problem. Nonetheless, relatively limited attention is given to gully erosion. This likely results from insufficient awareness and understanding of this process. Developing adequate policies to deal with gully erosion requires reliable, spatially explicit indicators on where this problem occurs. Furthermore, it requires tools and data to assess the effectiveness and efficiency of soil conservation measures. This is especially pertinent since gully erosion generally requires interventions that are more drastic and expensive than for sheet and rill erosion (e.g. Valentin et al., 2005; Bartley et al., 2020).

Holistically addressing the problem of soil erosion and land degradation requires models that can simulate and assess all relevant erosion processes, as well as their impacts on catchment sediment budgets (e.g. 

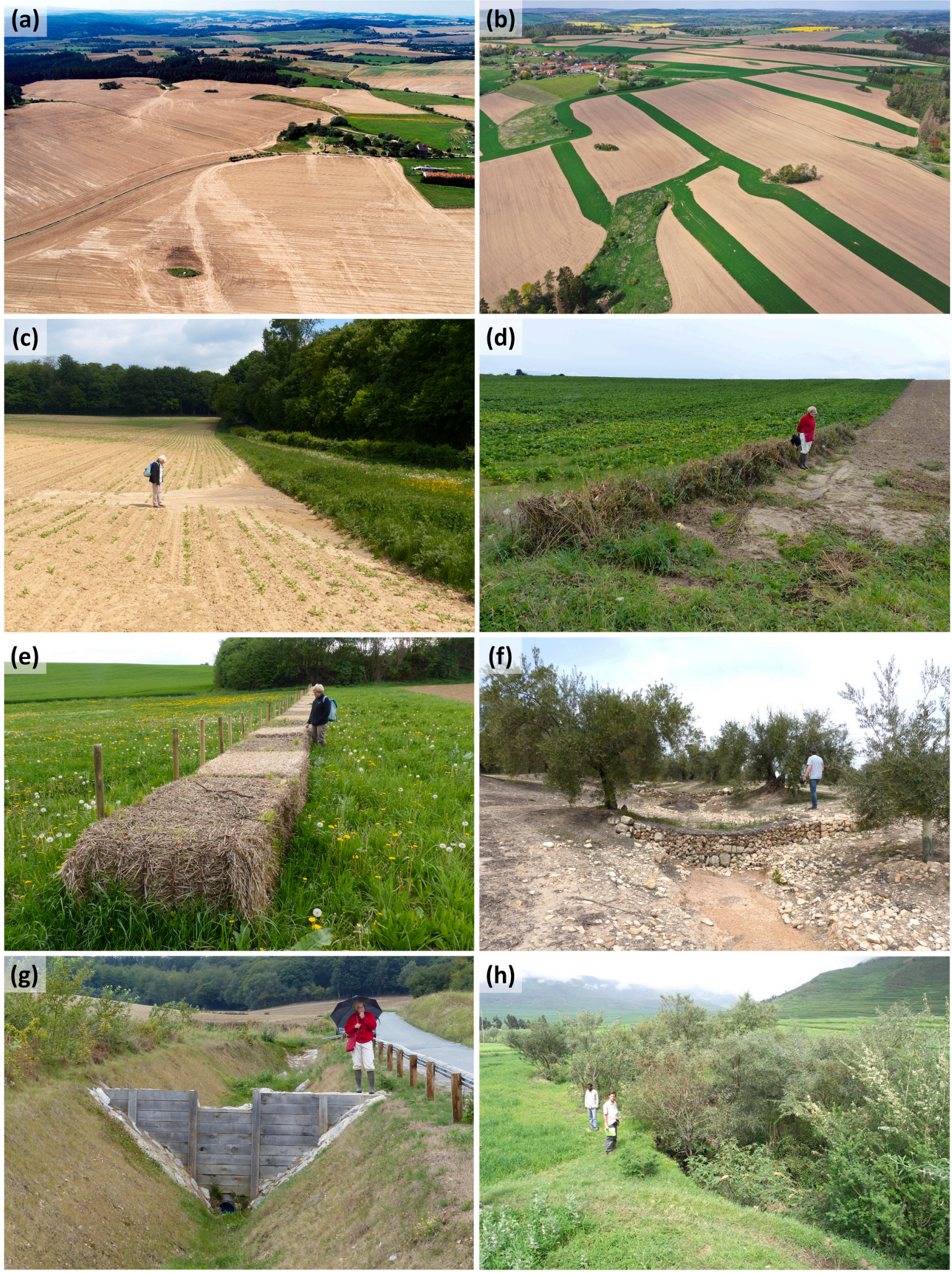

(h)

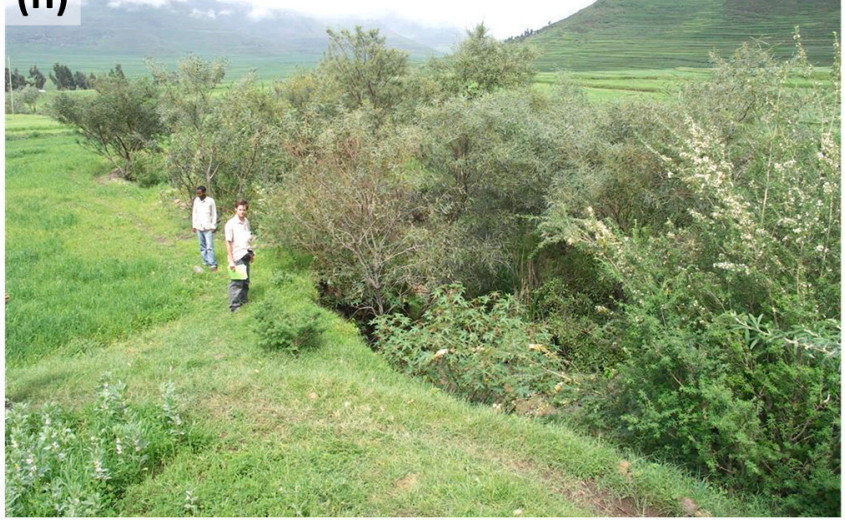




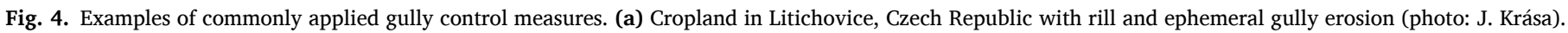

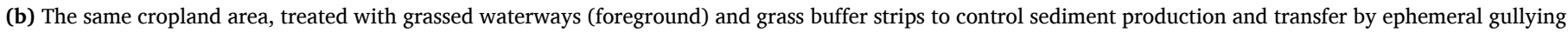

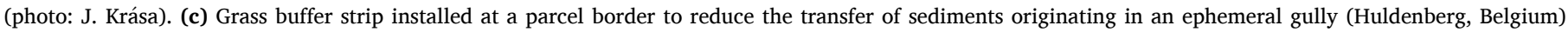

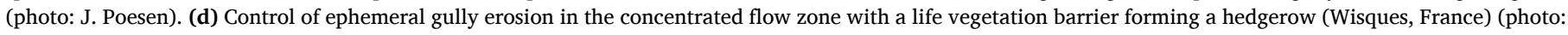

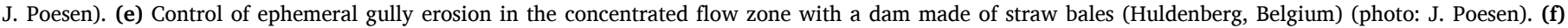

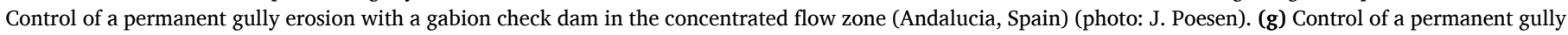

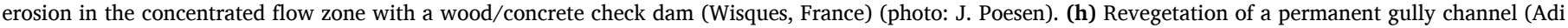
Shuhu, Ethiopia) (photo: J. Poesen).

Borrelli et al., 2018; Poesen, 2018). While detailed models and maps at the European and global level exist to assess sheet and rill erosion (e.g. Borrelli et al., 2017a) this is clearly not the case for gully erosion (cf. Sections 3 and 4). Our current inability to quantify gully erosion and its impacts should not imply that this process should remain neglected in policies. Building on the already extensive scientific knowledge gained in several regions worldwide (e.g. USDA, 2007; Sabir et al., 2020), EU and national/regional agro-environmental policies should aim to address, prevent and mitigate gully erosion and its impacts. It deserves mentioning that the EU already makes important efforts in this regard, including through initiatives like the 'Land Use/Cover Area frame statistical Survey Soil' (LUCAS; e.g. Blum et al., 2004; Panagos et al., 2015b; Borrelli et al., 2017b; Orgiazzi et al., 2018) which aims at monitoring soil health in the EU. In the LUCAS 2018 campaign, a soil erosion module was introduced where different processes of soil erosion (including gully erosion) were assessed for more than 20,000 visited points across the EU (Borrelli et al., submitted).

\section{Conclusions and recommendations}

Gully erosion is an important land degradation process, leading to major on- and off-site impacts (cf. Section 1). Climate change and land use/land cover changes may aggravate these impacts in many regions. Adequately addressing land degradation in a context of global change therefore requires strategies and policies that specifically account for gully erosion. However, the development of these is strongly hampered by our inability to accurately quantify and simulate gully erosion in relation to its driving factors, especially at larger (i.e. regional to global) scales. More specifically, we need tools and models that are capable of:

(i) identifying gully erosion hotspots;

(ii) quantifying gully erosion rates at different spatio-temporal scales;

(iii) assessing the impacts of gullies, including their (direct and indirect) contribution to catchment sediment yields; and

(iv) simulating the effects of land use/land cover changes, climate change, land management and conservation measures on gully erosion and its impacts.

While the development of such tools and models poses an important challenge, significant progress has been made over recent decades. Based on a review of over 590 scientific publications and policy documents, this article presents a state-of-the-art on monitoring, modelling and managing gully erosion at larger scales. Here we list our key conclusions and recommendations regarding these three aspects.

\subsection{Gully monitoring}

Monitoring the occurrence and dynamics of gully systems remains essential for better understanding and constraining rates and controlling factors of gully erosion. Especially datasets on the initiation and evolution of gully systems over large areas are a prerequisite for the development of models that can simulate this process at larger scales. Such datasets currently remain scarce. New remote sensing products can greatly help in addressing this gap. Nevertheless, monitoring gully erosion at larger scales remains highly labour-intensive and/or requires significant concessions in accuracy, completeness and level of detail (cf.
Section 2). Also the limited length of the observation periods and the coarse temporal resolution often form important constraints.

We make the following recommendations with respect to gully monitoring via remote sensing:

(i) Further research is needed to develop approaches that allow assessing the occurrence, properties and evolution of gully systems at larger spatial scales in efficient and accurate ways. Promising avenues for this are strategies that rely on monitoring gullies in large sets of small yet representative case study areas and the (semi-)automatic detection and characterization of gullies.

(ii) More studies are needed that provide data on the dynamics of gully erosion at high temporal resolutions across different environmental settings. This is particularly relevant for ephemeral gullies which may be formed and erased again over short time spans, potentially leading to significant underestimations of their erosion rates. Repeated analyses of frequent imagery, preferably taken shortly after every significant runoff event is likely the best way to address this need. The increasing availability of EO products at high spatio-temporal and spectral resolutions opens promising perspectives here.

(iii) Better insight and data are needed on the long-term evolution of gully systems. Gullies often form and expand over short time periods and then remain stable for many years. In some environments they may even be filled in again. Likewise, apparently stable gullies may be reactivated as a result of extreme climatic events or land cover/use/management changes. Nonetheless, most of the available data on gully erosion rates cover relatively short time periods (i.e. a few years) and are not necessarily representative for long-term average erosion rates. Systematically assessing the evolution of both active and seemingly stable gullies over decadal timescales will help addressing this need. Historical (aerial) photos and early satellite imagery can be an important asset for this.

(iv) Methodological advancements are required that allow better quantifying the uncertainties associated with gully monitoring. Assessed gully dimensions and dynamics are often subject to considerable uncertainties as a result of mapping errors, observation biases, the large temporal variability of gully erosion and conversion errors (e.g. when deriving gully volumes from gully lengths or areas). We recommend more research that allows quantifying these different sources of uncertainty, as well as their combined effects on the total uncertainty. Linked to that, we recommend developing procedures that allow better comparisons of collected data. Classifying gullies according to a consistent typology across different studies will be an important element in this.

Apart from remote sensing, also field-based research in well-targeted areas will remain essential to understand gully erosion. Our overview for Europe (Section 3) may serve as a starting point for future studies aiming to develop gully erosion models at regional to continental scales. However, it also uncovered shortcomings and gaps. For example, most studies focused on permanent gullies, while bank gullies and ephemeral gullies received considerably less attention. Nonetheless, their associated impacts can be very high. Other pertinent research needs include: 
(i) studies that monitor gully densities and gully expansion rates systematically over larger areas;

(ii) studies that monitor gully dynamics (i.e. initiation, headcut retreat, but also gully widening, deepening and infilling) and related subprocesses (e.g. piping, mass movement) at decadal timescales, preferably at high temporal resolutions;

(iii) studies that evaluate the performance of different gully modelling strategies based on detailed field observations; and

(iv) studies that assess the effectiveness of different gully erosion control measures over sufficiently long time periods.

\subsection{Gully modelling}

There is an important need for models and tools that can simulate and predict gully erosion at regional to global scales. Various viable model approaches and concepts have already been proposed, but need to be further developed, upscaled and tested so that they can be applied at larger scales (cf. Section 4). A major challenge is finding a good balance between an accurate process representation and feasible data requirements. The recent and ongoing development of new environmental data products at (sub)continental to global scales opens promising perspectives in this regard (cf. Section 5).

More specifically, process-oriented model approaches can yield relevant insights into the factors and mechanisms driving gully erosion, as well as their interactions. As such, they can be important tools for scenario analyses. However, their generally high data requirements make it difficult to apply them, especially at larger scales. Empirical modelling strategies, and in particular machine-learning approaches, offer great potential. However, their overall 'black box' nature can impede clear insights into the actual drivers of gully erosion. Different modelling strategies will therefore need to be developed and combined.

We make the following recommendations with respect to modelling gully erosion and its impacts:

(i) Better insights are needed on the factors controlling gully erosion at larger scales and how the role of these factors can be translated into meaningful variables and proxies that can be derived from GIS/EO data. This is especially so for the effects of climate and weather conditions, vegetation cover, land use/management, soil and lithological properties.

(ii) While numerous modelling strategies have already been proposed, more work is required to scale up these approaches from case studies to larger regions. This is the case for process-oriented strategies (e.g. relying on a spatially explicit hydrological model) as well as for empirical (e.g. machine learning) approaches. Much of this work will revolve around finding optimal trade-offs between model accuracy and feasible data and calculation requirements.

(iii) The potential to couple and combine different approaches needs to be further explored and developed. Most efforts so far have focussed on simulating either gully initiation, density or expansion (mainly through headcut retreat), while little research has been conducted on how to integrate these different aspects into models that predict total gully erosion rates. Such integration will also need accounting for potential interactions between these different components of gully erosion and their controlling factors as well as with potential interactions with other erosion processes (e.g. sheet and rill erosion).

(iv) Additional research is necessary on accounting for the effects of land use and land management practices, and in particular soil and water conservation measures, on gully erosion and its impacts at larger scales. This will require further developing largescale datasets indicating the presence of specific erosion control measures but also modelling frameworks that allow quantifying their effectiveness and efficiency. (v) There is a large need for tools and model frameworks that allow better assessing and quantifying the diverse on- and off-site impacts of gully erosion, both at short and longer timescales. This includes the effects of gully erosion on hillslope hydrology, crop yields, biomass production and other ecosystem services of soils, but also downstream impacts (e.g. assessing the contribution of gullies to river sediment load and catchment hydrology). This will likely require coupling gully erosion models to available models, but also developing new model components (e.g. accounting for the impacts of gullies on sediment connectivity).

(vi) On a more general level, the potential of models to simulate gully erosion and its impacts for scenario analyses needs to be further developed and tested. A key element in this will be the thorough validation of these models, using reliable observations over a large range of environmental conditions.

\subsection{Gully management}

Overall, there is a significant and growing international interest to tackle the challenges of soil erosion and land degradation in the context of global change (cf. Section 6). In Europe, numerous frameworks and policies help addressing the problem of soil erosion. However, very few of them explicitly account for (or even mention) gully erosion. More specific guidelines and recommendations to deal with this process are required. To a large extent, the absence of gully erosion in current policies is mainly due to our inability to accurately assess and quantify this process and its impacts. This hampers effective communication between scientists and policy makers on setting realistic targets and solutions. Nevertheless, our current state of knowledge does already allow accounting more explicitly for gully erosion.

We believe the following elements can aid in a better management of gully erosion at larger scales:

(i) Scientific initiatives that help to better quantify and understand gully erosion, allowing for more targeted policies, need to be further supported. Especially initiatives that help identifying (potentially) problematic areas and assessing the effectiveness, costs and benefits of prevention and control measures are needed in this regard.

(ii) Lessons learned from other policy implementations (e.g. with respect to sheet and rill erosion) as well as from regions where gully control measures are already implemented should be integrated in policies dealing with gully erosion.

(iii) Given that the formation, expansion rates and impacts of gullies strongly vary between regions, (future) policy instruments should accommodate for this diversity of contexts.

\section{Declaration of Competing Interest}

None.

\section{Acknowledgements}

We thank the Joint Research Centre (JRC), European Commission for organizing the workshop on gully erosion (March 2018) that led to the idea of this paper. Most of this article has been written during the COVID-19 lockdown. We therefore dedicate this paper to the many victims of this pandemic, as well as to the numerous health workers, scientists and policy makers that try to keep it at bay.

\section{References}

Abbasi, N.A., Xu, X., Lucas-Borja, M.E., Dang, W., Liu, B., 2019. The use of check dams in watershed management projects: examples from around the world. Sci. Total Environ. 676, 683-691. 
Adler, R.F., Huffman, G.J., Chang, A., Ferraro, R., Xie, P.P., Janowiak, J., Gruber, A., 2003. The version-2 global precipitation climatology project (GPCP) monthly precipitation analysis (1979-present). J. Hydrometeorol. 4 (6), 1147-1167.

Akgün, A., Türk, N., 2011. Mapping erosion susceptibility by a multivariate statistical method: a case study from the Ayvalık region, NW Turkey. Comput. Geosci. 37 (9), 1515-1524.

Al-Abadi, A.M., Al-Ali, A.K., 2018. Susceptibility mapping of gully erosion using GISbased statistical bivariate models: a case study from Ali Al-Gharbi District, Maysan Governorate, southern Iraq. Environ. Earth Sci. 77 (6), 249.

Albaladejo, J., Díaz-Pereira, E., de Vente, J., 2021. Eco-holistic soil conservation to support land degradation neutrality and the sustainable development goals. Catena 196, 104823.

Alganci, U., Besol, B., Sertel, E., 2018. Accuracy assessment of different digital surface models. ISPRS Int. J. Geo Inf. 7 (3), 114.

Allen, P.M., Arnold, J.G., Auguste, L., White, J., Dunbar, J., 2018. Application of a simple headcut advance model for gullies. Earth Surf. Process. Landf. 43 (1), 202-217.

Alonso, C.V., Bennett, S.J., Stein, O.R., 2002. Predicting head cut erosion and migration in concentrated flows typical of upland areas. Water Resour. Res. 38 (12), 39-1.

Alström, K., Åkerman, A.B., 1992. Contemporary soil erosion rates on arable land in southern Sweden. Geogr. Ann. Ser. A Phys. Geogr. 74 (2-3), 101-108.

Amare, S., Keesstra, S., van der Ploeg, M., Langendoen, E., Steenhuis, T., Tilahun, S., 2019. Causes and controlling factors of Valley bottom Gullies. Land 8 (9), 141.

Angileri, S.A., Conoscenti, C., Hochschild, V., Maerker, M., Rotigliano, E., Agnesi, V., 2016. Water erosion susceptibility mapping by applying stochastic gradient treeboost to the Imera Meridionale River basin (Sicily, Italy). Geomorphology 262, 61-76.

Arabameri, A., Rezaei, K., Pourghasemi, H.R., Lee, S., Yamani, M., 2018a. GIS-based gully erosion susceptibility mapping: a comparison among three data-driven models and AHP knowledge-based technique. Environ. Earth Sci. 77 (17), 628.

Arabameri, A., Pradhan, B., Pourghasemi, H.R., Rezaei, K., Kerle, N., 2018b. Spatial modelling of gully erosion using GIS and R programing: a comparison among three data mining algorithms. Appl. Sci. 8 (8), 1369.

Arnould-De Bontridder, O., Paulis, L., 1966. Étude du ravinement Holocene en Forêt de Soignes. Acta Geogr. Lovan. 4, 182-191.

Asch, K., 2005. IGME 5000: 1: 5 Million International Geological Map of Europe and Adjacent Areas. BGR (Hannover).

Ashouri, H., Hsu, K.L., Sorooshian, S., Braithwaite, D.K., Knapp, K.R., Cecil, L.D., Prat, O. P., 2015. PERSIANN-CDR: Daily precipitation climate data record from multisatellite observations for hydrological and climate studies. Bull. Am. Meteorol. Soc. 96 (1), 69-83.

Auzet, A.V., Boiffin, J., Papy, F., Ludwig, B., Maucorps, J., 1993. Rill erosion as a function of the characteristics of cultivated catchments in the north of France. Catena 20 (1-2), 41-62.

Avni, Y., 2005. Gully incision as a key factor in desertification in an arid environment, the Negev highlands, Israel. Catena 63 (2-3), 185-220.

Ayele, G.K., Addisie, M.B., Langendoen, E.J., Tegegne, N.H., Tilahun, S.A., Moges, M.A., Kees, T.S., 2018. Evaluating erosion control practices in an actively gullying watershed in the highlands of Ethiopia. Earth Surf. Process. Landf. 43 (13), 2835-2843.

Báčová, M., Krasa, J., 2016. Application of historical and recent aerial imagery in monitoring water erosion occurrences in Czech highlands. Soil Water Res. 11 (4), 267-276.

Bakker, M.M., Govers, G., Kosmas, C., Vanacker, V., Van Oost, K., Rounsevell, M., 2005 Soil erosion as a driver of land-use change. Agric. Ecosyst. Environ. 105 (3), 467-481.

Ballabio, C., Panagos, P., Monatanarella, L., 2016. Mapping topsoil physical properties at European scale using the LUCAS database. Geoderma 261, 110-123.

Ballabio, C., Lugato, E., Fernández-Ugalde, O., Orgiazzi, A., Jones, A., Borrelli, P., Panagos, P., 2019. Mapping LUCAS topsoil chemical properties at European scale using Gaussian process regression. Geoderma 355, 113912.

Ballesteros Cánovas, J., Stoffel, M., Martín-Duque, J.F., Corona, C., Lucía, A., Bodoque, J. M., Montgomery, D.R., 2017. Gully evolution and geomorphic adjustments of badlands to reforestation. Sci. Rep. 7, 45027.

Bannari, A., Morin, D., Bonn, F., Huete, A.R., 1995. A review of vegetation indicesremote sensing reviews. Remote Sens. Rev. https://doi.org/10.1080/ 02757259509532298.

Barati, S., Rayegani, B., Saati, M., Sharifi, A., Nasri, M., 2011. Comparison the accuracie of different spectral indices for estimation of vegetation cover fraction in sparse vegetated areas. Egypt. J. Remote Sens. Space Sci. 14 (1), 49-56.

Bartley, R., Poesen, J., Wilkinson, S., Vanmaercke, M., 2020. A review of the magnitude and response times for sediment yield reductions following the rehabilitation of gullied landscapes. Earth-Surf. Proc. Landforms 24, 3250-3279. https://doi.org/ 10.1002/esp.4963.

Battaglia, S., Leoni, L., Sartori, F., 2003. Mineralogical and grain size composition of clays developing calanchi and biancane erosional landforms. Geomorphology 49 (1-2), 153-170.

Battaglia, S., Leoni, L., Rapetti, F., Spagnolo, M., 2011. Dynamic evolution of badlands in the Roglio basin (Tuscany, Italy). Catena 86 (1), 14-23.

Bauer, A., 1993. Bodenerosion in den Waldgebieten des östlichen Taunus in historische und heutiger Zeit - Ausmaß, Ursachen und geoökologische Auswirkungen. Frankf. Geowissensch. Arbeiten D14.

Beck, H.E., Van Dijk, A.I., Levizzani, V., Schellekens, J., Gonzalez Miralles, D., Martens, B., De Roo, A., 2017. MSWEP: 3-hourly 0.25 global gridded precipitation (1979-2015) by merging gauge, satellite, and reanalysis data. Hydrol. Earth Syst. Sci. 21 (1), 589-615.
Begin, Z.B., Schumm, S.A., 1979. Instability of alluvial valley floors: a method for its assessment. Trans. ASAE 22 (2), 347-0350.

Belward, A.S., Skøien, J.O., 2015. Who launched what, when and why; trends in global land-cover observation capacity from civilian earth observation satellites. ISPRS J. Photogramm. Remote Sens. 103, 115-128.

Belyaev, V., Golosov, V., Kislenko, K., Kuznetsova, J., Markelov, M., 2008. Combining direct observations, modelling, and 137Cs tracer for evaluating individual event contribution to long-term sediment budgets. Sedim. Dynam. Chang. Environ. 325, 114.

Belyaev, V.R., Wallbrink, P.J., Golosov, V.N., Murray, A.S., Sidorchuk, A.Y., 2004. Reconstructing the development of a gully in the Upper Kalaus basin, Stavropol Region (southern Russia). Earth Surf. Proc. Landf. J. Br. Geomorphol. Res. Group 29 (3), 323-341.

Belyaev, V.R., Eremenko, E.A., Panin, A.V., Belyaev, Y.R., 2005a. Stages of late Holocene gully development in the central Russian Plain. Int. J. Sedim. Res. 20 (3), 224.

Belyaev, V.R., Wallbrink, P.J., Golosov, V.N., Murray, A.S., Sidorchuk, A.Yu., 2005b. A comparison of methods for evaluating soil redistribution in the severely eroded Stavropol region, southern European Russia. Geomorphology 65 (3-4), 173-193.

Benda, L., Miller, D., Bigelow, P., Andras, K., 2003. Effects of post-wildfire erosion on channel environments, Boise River, Idaho. For. Ecol. Manag. 178 (1-2), 105-119.

Bennett, S.J., Wells, R.R., 2019. Gully erosion processes, disciplinary fragmentation, and technological innovation. Earth Surf. Process. Landf. 44 (1), 46-53.

Bergonse, R., Reis, E., 2016. Controlling factors of the size and location of large gully systems: a regression-based exploration using reconstructed pre-erosion topography. Catena 147, 621-631.

Bernard, J., Bingner, R.L., Dabney, S.M., Langendoen, E.J., Lemunyon, J., Merkel, W., Wilson, G.V., 2010. Ephemeral gully erosion-a national resource concern. Nation. Sediment. Lab. Techn. Res. Rep. 69.

Bernatek-Jakiel, A., Poesen, J., 2018. Subsurface erosion by soil piping: significance and research needs. Earth Sci. Rev. 185, 1107-1128.

Bernatek-Jakiel, A., Wrońska-Wałach, D., 2018. Impact of piping on gully development in mid-altitude mountains under a temperate climate: a dendrogeomorphological approach. Catena 165, 320-332.

Beyer, A., 2008. Mittelalterlich-neuzeitliche Landschaftsentwicklung im Südsolling. Die Dorfwüstung Winnefeld. PhD thesis. University of Kiel. URL: http://www.kndw-ev. de/PDF/Dissertation_Arno_Beyer.pdf.

Bianchini, S., Del Soldato, M., Solari, L., Nolesini, T., Pratesi, F., Moretti, S., 2016. Badland susceptibility assessment in Volterra municipality (Tuscany, Italy) by means of GIS and statistical analysis. Environ. Earth Sci. 75 (10), 889.

Bicheron, P., Defourny, P., Brockmann, C., Schouten, L., Vancutsem, C., Huc, M., Ranera, F., 2008. GLOBCOVER: Products Description and Validation Report.

Bielders, C.L., Ramelot, C., Persoons, E., 2003. Farmer perception of runoff and erosion and extent of flooding in the silt-loam belt of the Belgian Walloon Region. Environ. Sci. Pol. 6 (1), 85-93.

Blöschl, G., 2006. Rainfall-runoff modeling of ungauged catchments. In: Encyclopedia of Hydrological Sciences. John Wiley and Sons, Ltd.

Blum, W.E., Büsing, J., Montanarella, L., 2004. Research needs in support of the European thematic strategy for soil protection. TrAC Trends Anal. Chem. 23 (10-11), 680-685.

Boardman, J., 1983. Soil erosion at Albourne, West Sussex, England. Appl. Geogr. 3 (4), 317-329.

Boardman, J., 1988. Severe erosion on agricultural land in East Sussex, UK October 1987. Soil Technol. 1 (4), 333-348.

Boardman, J., 2001. Storms, floods and soil erosion on the South Downs, East Sussex, autumn and winter 2000-01. Geography 346-355.

Boardman, J., 2012. Soil erosion and farming: assessing the risk. Geogr. Rev. 26, 36-40.

Boardman, J., 2013. Soil erosion in Britain: updating the record. Agriculture 3 (3), 418-442.

Boardman, J., Burt, T.P., Evans, R., Slattery, M.C., Shuttleworth, H., 1996. Soil erosion and flooding as a result of a summer thunderstorm in Oxfordshire and Berkshire, May 1993. Appl. Geogr. 16 (1), 21-34.

Boardman, J., Shepheard, M.L., Walker, E., Foster, I.D., 2009. Soil erosion and riskassessment for on-and off-farm impacts: a test case using the Midhurst area, West Sussex, UK. J. Environ. Manag. 90 (8), 2578-2588.

Boardman, J., Burt, T., Foster, I., 2020. Monitoring soil erosion on agricultural land: results and implications for the Rother valley, West Sussex, UK. Earth Surf. Process. Landf. 45 (15), 3931-3942.

Boengiu, S., Vladut, A., Marinescu, E., 2012. Conditions of gully development within Piedmont areas with examples from the western part of the Getic Piedmont, Romania. J. Environ. Biol. 33 (2), 407.

Bogen, J., Berg, H., Sandersen, F., 1994. The contribution of gully erosion to the sediment budget of the River Leira. IAHS Publ. Ser. Proc. Rep. Int. Assoc. Hydrol. Sci. 224, 307-316.

Bollati, I.M., Masseroli, A., Mortara, G., Pelfini, M., Trombino, L., 2019. Alpine gullies system evolution: erosion drivers and control factors. Two examples from the western Italian Alps. Geomorphology 327, 248-263.

Bolysov, S., Tarzaeva, N., 1996. Meteorologičeskij faktor v razvitii regressivnoj èrozii na ûgo-zapade Podmoskov'â. Geomorfol. (Moskva) 4, 97-103 (in Russian).

Bolysov, S.I., 1987. Factors and velocities of current retrogressive erosion in the south West of the Moscow region (in the Protva river basin). Erozionnee i karstovye process na territorii centra Russkoi ravniny, Moscow, pp. 48-55 (in Russian).

Bontemps, S., Defourny, P., Van Bogaert, E., Arino, O., Kalogirou, V., Perez, J.R., 2011. GLOBCOVER 2009-Products Description and Validation Report. URL: http://ionia1. esrin.esa.int/docs/GLOBCOVER2009_Validation_Report_2.

Bork, H.-R., 1985. Mittelalterliche und neuzeitliche lineare Bodenerosion in Südniedersachsen. Hercynia N.F 22, 259-279. 
Bork, H.-R., Rohdenburg, H., 1979. Beispiele für jungholozäne Bodenerosion und Bodenbildung im Untereichsfeld und Randgebieten. Landschaftsgenese Landschaftsökologie 3, 115-134.

Bork, H.-R., Bork, H., Dalchow, C., Faust, B., Piorr, H.-P., Schatz, T., 1998. Landschaftsentwicklung in Mitteleuropa - Wirkungen des Menschen auf Landschaften. Klett-Perthes, Gotha.

Borrelli, P., Ballabio, C., Panagos, P., Montanarella, L., 2014. Wind erosion susceptibility of European soils. Geoderma 232, 471-478.

Borrelli, P., Paustian, K., Panagos, P., Jones, A., Schütt, B., Lugato, E., 2016. Effect of good agricultural and environmental conditions on erosion and soil organic carbon balance: a national case study. Land Use Policy 50, 408-421.

Borrelli, P., Poesen, J., Vanmaercke, M., Ballabio, C., Hervás, J., Scarpa, S., Maerker, M., Panagos, P. Monitoring gully erosion in the European Union: a novel approach based on the Land Use/Cover Area frame Survey (LUCAS). Soil and Water Conservation: submitted.

Borrelli, P., Robinson, D.A., Fleischer, L.R., Lugato, E., Ballabio, C., Alewell, C., Bagarello, V., 2017a. An assessment of the global impact of 21st century land use change on soil erosion. Nat. Commun. 8 (1), 1-13.

Borrelli, P., Lugato, E., Montanarella, L., Panagos, P., 2017b. A new assessment of soil loss due to wind erosion in European agricultural soils using a quantitative spatially distributed modelling approach. Land Degrad. Dev. 28 (1), 335-344.

Borrelli, P., Van Oost, K., Meusburger, K., Alewell, C., Lugato, E., Panagos, P., 2018. A step towards a holistic assessment of soil degradation in Europe: coupling on-site erosion with sediment transfer and carbon fluxes. Environ. Res. 161, 291-298.

Borselli, L., Cassi, P., Torri, D., 2008. Prolegomena to sediment and flow connectivity in the landscape: a GIS and field numerical assessment. Catena 75 (3), 268-277.

Bosino, A., Omran, A., Maerker, M., 2019. Identification, characterisation and analysis of the Oltrepo Pavese calanchi in the Northern Apennines (Italy). Geomorphology 340, 53-66.

Boulton, S.J., Stokes, M., 2018. Which DEM is best for analyzing fluvial landscape development in mountainous terrains? Geomorphology 310, 168-187.

Bouma, J., 2019. How to communicate soil expertise more effectively in the information age when aiming at the UN Sustainable Development Goals. Soil Use Manag. 35 (1), $32-38$.

Brooks, A.P., Shellberg, J.G., Knight, J., Spencer, J., 2009. Alluvial gully erosion: an example from the Mitchell fluvial megafan, Queensland, Australia. Earth Surf. Proc. Landf. J. Br. Geomorphol. Res. Group 34 (14), 1951-1969.

Buccolini, M., Coco, L., 2010. The role of the hillside in determining the morphometric characteristics of "calanchi": the example of Adriatic Central Italy. Geomorphology 123 (3-4), 200-210.

Buccolini, M., Coco, L., 2013. MSI (morphometric slope index) for analyzing activation and evolution of calanchi in Italy. Geomorphology 191, 142-149.

Buchhorn, M., Smets, B., Bertels, L., Lesiv, M., Tsendbazar, N.E., Herold, M., Fritz, S., 2019. Copernicus global land service: land cover 100m: epoch 2015: Globe. Dataset Glob. Comp. Copernicus Land Monit. Serv. 2019.

Bučko, Š., Mazúrová, V., 1958. Gully erosion in Slovakia. In: Zachar, D. (Ed.), Water Erosion in Slovakia. SAS Publishing, Bratislava, pp. 68-101.

Burkard, M.B., Kostaschuk, R.A., 1997. Patterns and controls of gully growth along the shoreline of Lake Huron. Earth Surf. Proc. Landf. J. Br. Geomorphol. Group 22 (10), 901-911.

Büttner, G., Soukup, T., Kosztra, B., 2014. CLC2012 Addendum to CLC2006 Technical Guidelines. Final Draft, Copenhagen (EEA).

Campo-Bescós, M.A., Flores-Cervantes, J.H., Bras, R.L., Casalí, J., Giráldez, J.V., 2013. Evaluation of a gully headcut retreat model using multitemporal aerial photographs and digital elevation models. J. Geophys. Res. Earth Surf. 118 (4), 2159-2173.

Cánovas, J.B., Stoffel, M., Martín-Duque, J.F., Corona, C., Lucía, A., Bodoque, J.M., Montgomery, D.R., 2017. Gully evolution and geomorphic adjustments of badlands to reforestation. Sci. Rep. 7, 45027.

Cantón, Y., Domingo, F., Solé-Benet, A., Puigdefábregas, J., 2001. Hydrological and erosion response of a badlands system in semiarid SE Spain. J. Hydrol. 252 (1-4), 65-84.

Cappadonia, C., Conoscenti, C., Rotigliano, E., 2011. Monitoring of erosion on two calanchi fronts-Northern Sicily (Italy). Landform. Analys. 17, 21-25.

Capra, A., Scicolone, B., 2002. SW-soil and water: ephemeral gully Erosion in a wheatcultivated area in Sicily (Italy). Biosyst. Eng. 83 (1), 119-126.

Capra, A., Mazzara, L.M., Scicolone, B., 2005. Application of the EGEM model to predict ephemeral gully erosion in Sicily, Italy. Catena 59 (2), 133-146.

Capra, A., Porto, P., Scicolone, B., 2009. Relationships between rainfall characteristics and ephemeral gully erosion in a cultivated catchment in Sicily (Italy). Soil Tillage Res. 105 (1), 77-87.

Caraballo-Arias, N.A., Conoscenti, C., Di Stefano, C., Ferro, V., 2014. Testing GISmorphometric analysis of some Sicilian badlands. Catena 113, 370-376.

Caraballo-Arias, N.A., Conoscenti, C., Di Stefano, C., Ferro, V., 2015. A new empirical model for estimating calanchi Erosion in Sicily, Italy. Geomorphology 231, 292-300.

Caraballo-Arias, N.A., Conoscenti, C., Di Stefano, C., Ferro, V., Gómez-Gutiérrez, A., 2016. Morphometric and hydraulic geometry assessment of a gully in SW Spain. Geomorphology 274, 143-151.

Casalı, J., López, J.J., Giráldez, J.V., 1999. Ephemeral gully erosion in southern Navarra (Spain). Catena 36 (1-2), 65-84.

Casalí, J., Giménez, R., Campo-Bescós, M.A., 2015. Gully geometry: what are we measuring? Soil 1 (2), 509.

Castillo, C., Gómez, J.A., 2016. A century of gully erosion research: urgency, complexity and study approaches. Earth Sci. Rev. 160, 300-319.

Castillo, C., Pérez, R., James, M.R., Quinton, J.N., Taguas, E.V., Gómez, J.A., 2012. Comparing the accuracy of several field methods for measuring Gully erosion. Soil Sci. Soc. Am. J. 76 (4) https://doi.org/10.2136/sssaj2011.0390.
Castillo, C., Taguas, E.V., Zarco-Tejada, P., James, M.R., Gómez, J.A., 2014a. The normalized topographic method: an automated procedure for gully mapping using GIS. Earth Surf. Process. Landf. 39 (15), 2002-2015.

Castillo, C., Pérez Alcántara, R., Gómez Calero, J.A., 2014b. A Conceptual Model of Check Dam Hydraulics for Gully Control: Efficiency, Optimal Spacing and Relation with Step-Pools.

Castillo, C., Marín-Moreno, V.J., Pérez, R., Muñoz-Salinas, R., Taguas, E.V., 2018. Accurate automated assessment of gully cross-section geometry using the photogrammetric interface FreeXSapp. Earth Surf. Process. Landf. 43 (8), 1726-1736.

Castillo, C., Campo-Bescós, M.A., Giménez, R., Pérez, R., Casalí, J., 2019. The optimal lid method for the objective definition of cross-section limits in ephemeral gullies. Catena 176, 381-393.

Castillo, V.M., Mosch, W.M., García, C.C., Barberá, G.G., Cano, J.N., López-Bermúdez, F., 2007. Effectiveness and geomorphological impacts of check dams for soil erosion control in a semiarid Mediterranean catchment: El Cárcavo (Murcia, Spain). Catena 70 (3), 416-427.

Census of Agriculture, 2012. United States - Department of Agriculture. URL: http s://www.nass.usda.gov/Publications/\&oldid $=441343$.

Cerdan, O., Le Bissonnais, Y., Couturier, A., Bourennane, H., Souchère, V., 2002. Rill erosion on cultivated hillslopes during two extreme rainfall events in Normandy, France. Soil Tillage Res. 67 (1), 99-108.

Chen, J., Chen, J., Liao, A., Cao, X., Chen, L., Chen, X., Zhang, W., 2015. Global land cover mapping at $30 \mathrm{~m}$ resolution: a POK-based operational approach. ISPRS J. Photogramm. Remote Sens. 103, 7-27.

Chen, J., Cao, X., Peng, S., Ren, H., 2017. Analysis and applications of GlobeLand30: a review. ISPRS Int. J. Geo Inf. 6 (8), 230.

Chen, M., Xie, P., Janowiak, J.E., Arkin, P.A., 2002. Global land precipitation: a 50-yr monthly analysis based on gauge observations. J. Hydrometeorol. 3 (3), 249-266.

Chiverrell, R.C., Harvey, A.M., Foster, G.C., 2007. Hillslope gullying in the Solway Firth-Morecambe Bay region, Great Britain: responses to human impact and/or climatic deterioration? Geomorphology 84 (3-4), 317-343.

Ciccacci, S., Galiano, M., Roma, M.A., Salvatore, M.C., 2009. Morphodynamics and morphological changes of the last 50 years in a badland sample area of Southern Tuscany (Italy). Z. Geomorphol. 53 (3), 273-297.

Clapuyt, F., Vanacker, V., Van Oost, K., 2016. Reproducibility of UAV-based earth topography reconstructions based on Structure-from-Motion algorithms. Geomorphology 260, 4-15.

Clark, C., Vetere Arellano, A.L., 2004. The Louth storm and flood after 80 years. Weather 59 (3), 71-76.

Clarke, M.L., Rendell, H.M., 2006. Hindcasting extreme events: the occurrence and expression of damaging floods and landslides in Southern Italy. Land Degrad. Dev. 17 (4), 365-380.

Clarke, M.L., Rendell, H.M., 2010. Climate-driven decrease in erosion in extant Mediterranean badlands. Earth Surf. Process. Landf. 35 (11), 1281-1288.

Clay, G.D., Dixon, S., Evans, M.G., Rowson, J.G., Worrall, F., 2012. Carbon dioxide fluxes and DOC concentrations of eroding blanket peat gullies. Earth Surf. Process. Landf. 37 (5), 562-571.

Cocco, S., Brecciaroli, G., Agnelli, A., Weindorf, D., Corti, G., 2015. Soil genesis and evolution on calanchi (badland-like landform) of Central Italy. Geomorphology 248, 33-46.

Common Agricultural Policy (CAP) 2021-27, COM (2018) 392, 2018. Common Agricultural Policy (CAP) strategic plans - Proposal for a Regulation COM (2018), p. 392.

Common Agricultural Policy (CAP), 73/2009, 2020. https://eur-lex.europa.eu/LexUriS erv/LexUriServ.do?uri=OJ:L:2009:030:0016:0099:en:PDF.

Compo, G.P., Whitaker, J.S., Sardeshmukh, P.D., Matsui, N., Allan, R.J., Yin, X., Brönnimann, S., 2011. The twentieth century reanalysis project. Q. J. R. Meteorol. Soc. 137 (654), 1-28.

Conforti, M., Aucelli, P.P., Robustelli, G., Scarciglia, F., 2011. Geomorphology and GIS analysis for mapping gully erosion susceptibility in the Turbolo stream catchment (Northern Calabria, Italy). Nat. Hazards 56 (3), 881-898.

Conoscenti, C., Rotigliano, E., 2020. Predicting gully occurrence at watershed scale: comparing topographic indices and multivariate statistical models. Geomorphology 359, 107123.

Conoscenti, C., Agnesi, V., Angileri, S., Cappadonia, C., Rotigliano, E., Maerker, M., 2013. A GIS-based approach for gully erosion susceptibility modelling: a test in Sicily, Italy. Environ. Earth Sci. 70 (3), 1179-1195.

Conoscenti, C., Angileri, S., Cappadonia, C., Rotigliano, E., Agnesi, V., Maerker, M., 2014. Gully erosion susceptibility assessment by means of GIS-based logistic regression: a case of Sicily (Italy). Geomorphology 204, 399-411.

Conoscenti, C., Agnesi, V., Cama, M., Caraballo-Arias, N.A., Rotigliano, E., 2018. Assessment of gully erosion susceptibility using multivariate adaptive regression splines and accounting for terrain connectivity. Land Degrad. Dev. 29 (3), 724-736.

Cornes, R.C., van der Schrier, G., van den Besselaar, E.J., Jones, P.D., 2018. An ensemble version of the E-OBS temperature and precipitation data sets. Journal of Geophysical Research: Atmospheres 123 (17), 9391-9409.

Cox, R., Zentner, D.B., Rakotondrazafy, A.F.M., Rasoazanamparany, C.F., 2010. Shakedown in Madagascar: Occurrence of lavakas (erosional gullies) associated with seismic activity. Geology 38 (2), 179-182.

Crouch, R., 1987. The relationship of gully sidewall shape to sediment production. Aust. J. Soil Res. 25, 531-539.

Cruden, D.M., Varnes, D.J., 1996. Landslides: investigation and mitigation. Chapter 3Landslide types and processes. Transp. Res. Board Spec. Rep. 247.

Dabney, S.M., Vieira, D.A., Yoder, D.C., 2015. Predicting ephemeral gully erosion with RUSLER and EphGEE. Proc. Int. Assoc. Hydrol. Sci. 367, 72. 
Daggupati, P., Douglas-Mankin, K.R., Sheshukov, A.Y., 2013. Predicting ephemeral gully location and length using topographic index models. Trans. ASABE 56 (4), $1427-1440$.

Darr, S.D., Pringle, M.J., 2017. Improving gully density maps for modelling water quality within Great Barrier Reef Catchments. In: 22nd International Congress on Modelling and Simulation, Hobart, Tasmania, pp. 1920-1926. Australia.mssanz.org.au/ modsim 2017.

de Figueiredo, T., Fonseca, F., 1997. Les sols, les processus d'érosion et l'utilisation de la terre en montagne au Nord-Est du Portugal: Approche cartographique sur quelques zones du Parc Naturel de Montesinho. Réseau Erosion Bull. 17, 205-217. http://hdl. handle.net/10198/6481.

De Foucault, B., Colbeaux, J.P., Bonnet, T., Bracq, P., Courtecuisse, R., Debuyser, M. Louche, B., 1997. Les creuses de la region Nord/Pas-de-Calais: premiers resultats d'etudes multi-criteres. Ann. Soc. Geol. Nord 5, 385-394.

De Geeter, S., Poesen, J., Vanmaercke, M., 2020. Does the topographic threshold concept explain the initiation points of sunken lanes in the European loess belt? Catena 192, 104586.

De Luna Armenteros, E., Laguna Luna, A.M., Jean, P., Giráldez Cervera, J.V., 2004. Evolución de un sistema de cárcavas activas en el sureste español. Ingeniería del Agua 11 (1), 65-73.

De Ploey, J., 1977. Some experimental data on slopewash and wind action with reference to Quaternary morphogenesis in Belgium. Earth Surf. Proc. 2 (2-3), 101-115.

De Santisteban, L.M., Casalí, J., López, J.J., 2006. Assessing soil erosion rates in cultivated areas of Navarre (Spain). Earth Surf. Proc. Landf. J. Br. Geomorphol. Res. Group 31 (4), 487-506.

de Vente, J., Poesen, J., Verstraeten, G., 2005. The application of semi-quantitative methods and reservoir sedimentation rates for the prediction of basin sediment yield in Spain. J. Hydrol. 305 (1-4), 63-86.

de Vente, J., Poesen, J., Bazzoffi, P., Rompaey, A.V., Verstraeten, G., 2006. Predicting catchment sediment yield in Mediterranean environments: the importance of sediment sources and connectivity in Italian drainage basins. Earth Surf. Process. Landf. 31 (8), 1017-1034.

de Vente, J., Poesen, J., Verstraeten, G., Van Rompaey, A., Govers, G., 2008. Spatially distributed modelling of soil erosion and sediment yield at regional scales in Spain. Glob. Planet. Chang. 60 (3-4), 393-415.

de Vente, J., Poesen, J., Verstraeten, G., Govers, G., Vanmaercke, M., Van Rompaey, A., Boix-Fayos, C., 2013. Predicting soil erosion and sediment yield at regional scales: where do we stand? Earth Sci. Rev. 127, 16-29.

Dedkov, A.P., Boiko, F.F., Mozzherin, V.I., Butacov, G.P., Dvinskich, A.P., Yermolaev, O. P., Lapteva, N.N., Tukaiev, R.M., Nazarov, N.N., Korotina, N.M., Rysin, I.I., 1990. Ovrazhnaya eroziya vostoka Russkoi ravniny (Gully erosion on the East of Russian Plain). Kazan': Izd-vo Kazan. un-ta 142.

Dee, D.P., Uppala, S.M., Simmons, A.J., Berrisford, P., Poli, P., Kobayashi, S., Bechtold, P., 2011. The ERA-Interim reanalysis: Configuration and performance of the data assimilation system. Q. J. R. Meteorol. Soc. 137 (656), 553-597.

Desmet, P.J.J., Poesen, J., Govers, G., Vandaele, K., 1999. Importance of slope gradient and contributing area for optimal prediction of the initiation and trajectory of ephemeral gullies. Catena 37 (3-4), 377-392.

Dewitte, O., Daoudi, M., Bosco, C., Van Den Eeckhaut, M., 2015. Predicting the susceptibility to gully initiation in data-poor regions. Geomorphology $228,101-115$.

Didan, K., 2015. Mod13q1 Modis/Terra Vegetation Indices 16-Day L3 Global 250m sin Grid V006 [Data Set]. NASA EOSDIS LP DAAC: NASA EOSDIS LP DAAC.

Dimiceli, C., Carroll, M., Sohlberg, R., Kim, D.H., Kelly, M., Townshend, J.R.G., 2015. MOD44B MODIS/Terra Vegetation Continuous Fields Yearly L3 global 250 M SIN Grid V006, Data Set, NASA EOSDIS L. Process. DAAC.

Domazetović, F., Šiljeg, A., Lončar, N., Marić, I., 2019. Development of automated multicriteria GIS analysis of gully erosion susceptibility. Appl. Geogr. 112, 102083

Domlija, P., Bernat Gazibara, S., Arbanas, Ž., Mihalić Arbanas, S., 2019. Identification and mapping of soil erosion processes using the visual interpretation of LiDAR imagery. ISPRS Int. J. Geo Inf. 8 (10), 438.

Dóniz, J., Romero, C., Carmona, J., García, A., 2011. Erosion of cinder cones in Tenerife by gully formation, Canary Islands, Spain. Phys. Geogr. 32 (2), 139-160.

Donker, N.W., Damen, M.J., 1984. Gully system development and an assessment of gully initiation risk in Miocene deposits near Daroca-Spain in Present day geomorphological processes. Zeitschr. Geomorphol. Suppl. Stuttgart 49, 37-50.

Donnini, M., Marchesini, I., Zucchini, A., 2020. Geo-LiM: a new geo-lithological map for Central Europe (Germany, France, Switzerland, Austria, Slovenia, and Northern Italy) as a tool for the estimation of atmospheric CO2 consumption. J. Maps 16 (2), 43-55.

Dotterweich, M., 2003. Land use and soil erosion in northern Bavaria during the last 5000 Years. In: Long Term Hillslope and Fluvial System Modelling. Springer, Berlin, Heidelberg, pp. 201-229.

Dotterweich, M., 2008. The history of soil erosion and fluvial deposits in small catchments of Central Europe: deciphering the long-term interaction between humans and the environment-a review. Geomorphology 101 (1-2), 192-208.

Dotterweich, M., Schmitt, A., Schmidtchen, G., Bork, H.R., 2003. Quantifying historical gully erosion in northern Bavaria. Catena 50 (2-4), 135-150.

Dotterweich, M., Rodzik, J., Zgłobicki, W., Schmitt, A., Schmidtchen, G., Bork, H.R., 2012. High resolution gully erosion and sedimentation processes, and land use changes since the Bronze Age and future trajectories in the Kazimierz Dolny area (Nałęczów Plateau, SE-Poland). Catena 95, 50-62.

Dotterweich, M., Stankoviansky, M., Minár, J., Koco, Š., Papčo, P., 2013. Human induced soil erosion and gully system development in the Late Holocene and future perspectives on landscape evolution: the Myjava Hill Land, Slovakia. Geomorphology 201, 227-245.
Dotterweich, M., Wenzel, S., Schreg, R., Fülling, A., Engel, M., 2015. Land use history, floodplain development, and soil erosion in the vicinity of a millstone production center since the Iron Age in the Segbachtal near Mayen (eastern Eifel, Germany). In: EGU General Assembly Conference Abstracts, 17.

Dreibrodt, S., 2005. Detecting heavy precipitation events during the Holocene from soils, gully fills, colluvia and lake sediments-examples from the Belauer See catchment (northern Germany). Z. Dtsch. Ges. Geowiss. 156 (4), 573-588.

Dube, H.B., Mutema, M., Muchaonyerwa, P., Poesen, J., Chaplot, V., 2020. A global analysis of the morphology of linear erosion features. Catena 190, 104542.

Dumbrovsky, M., Drbal, K., Sobotková, V., Uhrová, J., 2019. An approach to identifying and evaluating the potential formation of ephemeral gullies in the conditions of the Czech Republic. Soil Water Res. 15 (1), 38-46.

Dunne, T., Zhang, W., Aubry, B.F., 1991. Effects of rainfall, vegetation, and microtopography on infiltration and runoff. Water Resour. Res. 27 (9), 2271-2285.

Easton, Z.M., Fuka, D.R., White, E.D., Collick, A.S., Ashagre, B., McCartney, M., Steenhuis, T.S., 2010. A multi basin SWAT model analysis of runoff and sedimentation in the Blue Nile, Ethiopia. Hydrol. Earth Syst. Sci. 14 (10), 1827-1841.

Ebita, A., Kobayashi, S., Ota, Y., Moriya, M., Kumabe, R., Onogi, K., Kamahori, H., 2011. The Japanese 55-year reanalysis "JRA-55": an interim report. Sola 7, 149-152.

EEA, 2015. High Resolution Layer: Small Woody Features (SWF) 2015 v. 1.2. URL: https ://land.copernicus.eu/pan-european/high-resolution-layers/small-woody-features/s mall-woody-features-2015?tab=metadata.

Erikstad, L., 1992. Recent Changes in the Landscape of the Marine Clays, Østfold, Southeast Norway.

Erktan, A., Rey, F., 2013. Linking sediment trapping efficiency with morphological traits of Salix tiller barriers on marly gully floors under ecological rehabilitation. Ecol. Eng. 51, 212-220.

ESA, 2017. Land Cover Cci: Product User Guide Version 2. 1-105: ESA.

EU Agricultural Census, 2010. European Commission, EUROSTAT Survey on Agricultural Production Methods. URL: https://ec.europa.eu/eurostat/statistics-explained/index. php?title=Survey_on_agricultural_production_methods\&oldid $=441343$.

EU COM(2019) 640, 2019. European Commission, The European Green Deal. URL. htt ps://eur-lex.europa.eu/legal-content/EN/TXT/?uri=COM\%3A2019\%3A640\% 3AFIN.

EU JRC, 2015. Cover Management Factor (C-Factor) for the EU. URL. https://esdac.jrc. ec.europa.eu/content/cover-management-factor-c-factor-eu.

Eustace, A., Pringle, M., Witte, C., 2009. Give me the dirt: detection of gully extent and volume using high-resolution lidar. In: Innovations in Remote Sensing and Photogrammetry. Springer, Berlin, Heidelberg, pp. 255-269.

Evans, M., Lindsay, J., 2010. High resolution quantification of gully erosion in upland peatlands at the landscape scale. Earth Surf. Process. Landf. 35 (8), 876-886.

Evans, R., 2013. Assessment and monitoring of accelerated water erosion of cultivated land - when will reality be acknowledged? Soil Use Manag. 29 (1), 105-118.

Evans, R., Nortcliff, S., 1978. Soil erosion in North Norfolk. J. Agric. Sci. 90 (1), 185-192.

Evrard, O., Bielders, C.L., Vandaele, K., van Wesemael, B., 2007. Spatial and temporal variation of muddy floods in Central Belgium, off-site impacts and potential control measures. Catena 70 (3), 443-454.

Evrard, O., Vandaele, K., van Wesemael, B., Bielders, C.L., 2008. A grassed waterway and earthen dams to control muddy floods from a cultivated catchment of the Belgian loess belt. Geomorphology 100 (3-4), 419-428.

Faivre, S., Pahernik, M., Maradin, M., 2011. The gully of Potovošća on the Island of Krk-the effects of a short-term rainfall event. Geol. Croatica 64 (1), 67-80.

Fan, Y., Miguez-Macho, G., Jobbágy, E.G., Jackson, R.B., Otero-Casal, C., 2017. Hydrologic regulation of plant rooting depth. Proc. Natl. Acad. Sci. 114 (40), 10572-10577.

FAO, 2016. Voluntary Guidelines for Sustainable Soil Management.

FAO/IIASA/ISRIC/ISSCAS/JRC, 2012. Harmonized World Soil Database (version 1.2) FAO, Rome, Italy and IIASA, Laxenburg, Austria.

Faulkner, H., 1995. Gully erosion associated with the expansion of unterraced almond cultivation in the coastal Sierra de Lujar, S. Spain. Land Degrad. Dev. 6 (3), 179-200.

Faulkner, H., Alexander, R., Zukowskyj, P., 2008. Slope-channel coupling between pipes, gullies and tributary channels in the Mocatán catchment badlands, Southeast Spain. Earth Surf. Proc. Landf. J. Br. Geomorphol. Res. Group 33 (8), 1242-1260.

Fernandes, J., Bateira, C., Soares, L., Faria, A., Oliveira, A., Hermenegildo, C., Gonçalves, J., 2017. SIMWE model application on susceptibility analysis to bank gully erosion in Alto Douro Wine Region agricultural terraces. Catena 153, 39-49.

Filipponi, F., Valentini, E., Nguyen Xuan, A., Guerra, C.A., Wolf, F., Andrzejak, M., Taramelli, A., 2018. Global MODIS fraction of green vegetation cover for monitoring abrupt and gradual vegetation changes. Remote Sens. 10 (4), 653.

Fiorucci, F., Ardizzone, F., Rossi, M., Torri, D., 2015. The use of stereoscopic satellite images to map rills and ephemeral gullies. Remote Sens. 7 (10), 14151-14178.

Flores-Cervantes, J.H., Istanbulluoglu, E., Bras, R.L., 2006. Development of gullies on the landscape: a model of headcut retreat resulting from plunge pool erosion. J. Geophys. Res. Earth Surf. 111 (F1).

Frankl, A., Nyssen, J., De Dapper, M., Haile, M., Billi, P., Munro, R.N., Poesen, J., 2011. Linking long-term gully and river channel dynamics to environmental change using repeat photography (Northern Ethiopia). Geomorphology 129 (3-4), 238-251.

Frankl, A., Poesen, J., Deckers, J., Haile, M., Nyssen, J., 2012. Gully head retreat rates in the semi-arid highlands of Northern Ethiopia. Geomorphology 173, 185-195.

Frankl, A., Poesen, J., Scholiers, N., Jacob, M., Haile, M., Deckers, J., Nyssen, J., 2013. Factors controlling the morphology and volume (V)-length (L) relations of permanent gullies in the northern Ethiopian Highlands. Earth Surf. Process. Landf. 38 (14), 1672-1684. 
Frankl, A., Stal, C., Abraha, A., Nyssen, J., Rieke-Zapp, D., De Wulf, A., Poesen, J., 2015. Detailed recording of gully morphology in 3D through image-based modelling. Catena 127, 92-101.

Frankl, A., Deckers, J., Moulaert, L., Van Damme, A., Haile, M., Poesen, J., Nyssen, J., 2016. Integrated solutions for combating gully erosion in areas prone to soil piping: innovations from the drylands of Northern Ethiopia. Land Degrad. Dev. 27 (8), 1797-1804.

Frankl, A., Prêtre, V., Nyssen, J., Salvador, P.G., 2018. The success of recent land management efforts to reduce soil erosion in northern France. Geomorphology 303, 84-93.

Frankl, A., Nyssen, J., Vanmaercke, M., Poesen, J., 2021. Gully prevention and control: techniques, failures and effectiveness. Earth Surf. Process. Landf. 46 (1), 220-238.

Friedl, M.A., Sulla-Menashe, D., Tan, B., Schneider, A., Ramankutty, N., Sibley, A., Huang, X., 2010. MODIS Collection 5 global land cover: algorithm refinements and characterization of new datasets. Remote Sens. Environ. 114 (1), 168-182.

Gábris, G., Kertész, Á., Zámbó, L., 2003. Land use change and gully formation over the last 200 years in a hilly catchment. Catena 50 (2-4), 151-164.

Gafurov, A.M., Rysin, I.I., Golosov, V.N., Grigoryev, I.I., Sharifullin, A.G., 2018. Estimation of the modern gully head retreat rate on the southern macroslope of the East European Plain using a set of instrumental methods. Moscow Univ. Bull. Ser. 5: Geogr. 5, 61-71.

García-Ruiz, J.M., Beguería, S., Lana-Renault, N., Nadal-Romero, E., Cerdà, A., 2017. Ongoing and emerging questions in water erosion studies. Land Degrad. Dev. 28 (1), 5-21.

Gawrysiak, L., Harasimiuk, M., 2012. Spatial diversity of gully density of the Lublin Upland and Roztocze Hills (SE Poland). In: Annales Universitatis Mariae CurieSklodowska, 67, p. 27 no. 1. De Gruyter Open Sp. z oo.

Gayen, A., Pourghasemi, H.R., Saha, S., Keesstra, S., Bai, S., 2019. Gully erosion susceptibility assessment and management of hazard-prone areas in India using different machine learning algorithms. Sci. Total Environ. 668, 124-138.

Geissen, V., Kampichler, C., López-de Llergo-Juárez, J.J., Galindo-Acántara, A., 2007. Superficial and subterranean soil erosion in Tabasco, tropical Mexico: development of a decision tree modeling approach. Geoderma 139 (3-4), 277-287.

Gelaro, R., McCarty, W., Suárez, M.J., Todling, R., Molod, A., Takacs, L., Wargan, K., 2017. The modern-era retrospective analysis for research and applications, version 2 (MERRA-2). J. Clim. 30 (14), 5419-5454.

Giménez, R., Marzolff, I., Campo, M.A., Seeger, M., Ries, J.B., Casalí, J., AlvarezMozos, J., 2009. Accuracy of high-resolution photogrammetric measurements of gullies with contrasting morphology. Earth Surf. Proc. Landf. J. Br. Geomorphol. Res. Group 34 (14), 1915-1926.

Gobin, A., Jones, R., Kirkby, M., Campling, P., Govers, G., Kosmas, C., Gentile, A.R., 2004. Indicators for pan-European assessment and monitoring of soil erosion by water. Environ. Sci. Pol. 7 (1), 25-38.

Golosov, V., Belyaev, V., 2013. The history and assessment of effectiveness of soil erosion control measures deployed in Russia. Int. Soil Water Conserv. Res. 1 (2), 26-35.

Golosov, V., Yermolaev, O., Rysin, I., Vanmaercke, M., Medvedeva, R., Zaytseva, M., 2018. Mapping and spatial-temporal assessment of gully density in the Middle Volga region, Russia. Earth Surf. Process. Landf. 43 (13), 2818-2834.

Gómez-Gutiérrez, Á., Schnabel, S., Felicísimo, Á.M., 2009c. Modelling the occurrence of gullies in rangelands of Southwest Spain. Earth Surf. Process. Landf. 34 (14), 1894-1902.

Gomez-Gutiérrez, Á., Schnabel, S., Contador, F.L., 2009a. Gully erosion, land use and topographical thresholds during the last 60 years in a small rangeland catchment in SW Spain. Land Degrad. Dev. 20 (5), 535-550.

Gomez-Gutiérrez, Á., Schnabel, S., Lavado Contador, J.F., 2009b. Using and comparing two nonparametric methods (CART and MARS) to model the potential distribution of gullies. Ecol. Modell. Select. Pap. Spat. Expl. Landscape Modell. Curr. Pract. Challeng. 220 (24), 3630-3637.

Gómez-Gutiérrez, Á., Schnabel, S., Berenguer-Sempere, F., Lavado-Contador, F., RubioDelgado, J., 2014. Using 3D photo-reconstruction methods to estimate gully headcut erosion. Catena 120, 91-101.

Gómez-Gutiérrez, Á., Conoscenti, C., Angileri, S.E., Rotigliano, E., Schnabel, S., 2015. Using topographical attributes to evaluate gully erosion proneness (susceptibility) in two mediterranean basins: advantages and limitations. Nat. Hazards 79 (1), 291-314.

Gong, P., Wang, J., Yu, L., Zhao, Y., Zhao, Y., Liang, L., Li, C., 2013. Finer resolution observation and monitoring of global land cover: first mapping results with Landsat TM and ETM+ data. Int. J. Remote Sens. 34 (7), 2607-2654.

Gonzalez, J.C.G., 2015. Eu-Dem Upgrade: Documentation Eea User Manual. 12. Copernicus.

Goodwin, N.R., Armston, J.D., Muir, J., Stiller, I., 2017. Monitoring gully change: a comparison of airborne and terrestrial laser scanning using a case study from Aratula, Queensland. Geomorphology 282, 195-208.

Gordon, L.M., Bennett, S.J., Bingner, R.L., Theurer, F.D., Alonso, C.V., 2007. Simulating ephemeral gully erosion in AnnAGNPS. Trans. ASABE 50 (3), 857-866.

Gordon, L.M., Bennett, S.J., Alonso, C.V., Bingner, R.L., 2008. Modeling long-term soil losses on agricultural fields due to ephemeral gully erosion. J. Soil Water Conserv. 63 (4), 173-181.

Gorelick, N., Hancher, M., Dixon, M., Ilyushchenko, S., Thau, D., Moore, R., 2017. Google earth engine: planetary-scale geospatial analysis for everyone. Remote Sens. Environ. 202, 18-27.

Govers, G., Poesen, J., 1988. Assessment of the interrill and rill contributions to total soil loss from an upland field plot. Geomorphology 1 (4), 343-354.

Graf, W.L., 1977. The rate law in fluvial geomorphology. Am. J. Sci. 277 (2), 178-191.

Grekousis, G., Mountrakis, G., Kavouras, M., 2015. An overview of 21 global and 43 regional land-cover mapping products. Int. J. Remote Sens. 36 (21), 5309-5335.
Guerra, A.J., Bezerra, J.F., Fullen, M.A., Mendonça, J.K.S., Sathler, R., Lima, F.S., Guerra, T.T., 2007. Urban gullies in Sao Luis city, Maranhao state, Brazil. In: Casalí, Javier, Giménez, Rafael (Eds.), Progress in Gully Erosion Research. IV International Symposium on Gully Erosion. September 17-19, 2007. Pamplona, Spain. Universidad Pública de Navarra/Nafarroako Unibertsitate Publikoa, Pamplona, 2007. Universidad Pública de Navarra/Nafarroako Unibertsitate Publikoa.

Gulam, V., Gajski, D., Podolszki, L., 2018. Photogrammetric measurement methods of the gully rock wall retreat in Istrian badlands. Catena 160, 298-309.

Gullentops, F., 1992. Holocene Soil Erosion in the Loess Belt of Belgium. Na.

Guyassa, E., Frankl, A., Zenebe, A., Poesen, J., Nyssen, J., 2017. Effects of check dams on runoff characteristics along gully reaches, the case of Northern Ethiopia. J. Hydrol. 545, 299-309.

Guyassa, E., Frankl, A., Zenebe, A., Poesen, J., Nyssen, J., 2018. Gully and soil and water conservation structure densities in semi-arid northern Ethiopia over the last 80 years. Earth Surf. Process. Landf. 43 (9), 1848-1859.

Gyssels, G., Poesen, J., 2003. The importance of plant root characteristics in controlling concentrated flow erosion rates. Earth Surf. Proc. Landf. J. Br. Geomorphol. Res. Group 28 (4), 371-384.

Gyssels, G., Poesen, J., Nachtergaele, J., Govers, G., 2002. The impact of sowing density of small grains on rill and ephemeral gully erosion in concentrated flow zones. Soil Tillage Res. 64 (3-4), 189-201.

Hancock, G.R., Evans, K.G., Willgoose, G.R., Moliere, D.R., Saynor, M.J., Loch, R.J., 2000. Medium-term erosion simulation of an abandoned mine site using the SIBERIA landscape evolution model. Soil Res. 38 (2), 249-264.

Hancock, G.R., Lowry, J.B.C., Coulthard, T.J., 2015. Catchment reconstruction—erosional stability at millennial time scales using landscape evolution models. Geomorphology 231, 15-27.

Haregeweyn, N., Poesen, J., Nyssen, J., Verstraeten, G., De Vente, J., Govers, G., Moeyersons, J., 2005. Specific sediment yield in Tigray-Northern Ethiopia: assessment and semi-quantitative modelling. Geomorphology 69 (1-4), 315-331.

Haregeweyn, N., Poesen, J., Nyssen, J., De Wit, J., Haile, M., Govers, G., Deckers, S., 2006. Reservoirs in Tigray (Northern Ethiopia): characteristics and sediment deposition problems. Land Degrad. Dev. 17 (2), 211-230.

Haregeweyn, N., Poesen, J., Deckers, J., Nyssen, J., Haile, M., Govers, G., Moeyersons, J., 2008. Sediment-bound nutrient export from micro-dam catchments in Northern Ethiopia. Land Degrad. Dev. 19 (2), 136-152.

Haregeweyn, N., Tsunekawa, A., Nyssen, J., Poesen, J., Tsubo, M., Tsegaye Meshesha, D., Tegegne, F., 2015. Soil erosion and conservation in Ethiopia: a review. Prog. Phys. Geogr. 39 (6), 750-774.

Haregeweyn, N., Tsunekawa, A., Poesen, J., Tsubo, M., Meshesha, D.T., Fenta, A.A., Adgo, E., 2017. Comprehensive assessment of soil erosion risk for better land use planning in river basins: case study of the Upper Blue Nile River. Sci. Total Environ. 574, 95-108.

Harmon, B.A., Mitasova, H., Petrasova, A., Petras, V., 2019. r. sim. terrain 1.0: a landscape evolution model with dynamic hydrology. Geosci. Model Dev. 12 (7).

Harris, I.P.D.J., Jones, P.D., Osborn, T.J., Lister, D.H., 2014. Updated high-resolution grids of monthly climatic observations-the CRU TS3. 10 Dataset. Int. J. Climatol. 34 (3), 623-642.

Hartmann, J., Moosdorf, N., 2012. The new global lithological map database GLiM: a representation of rock properties at the Earth surface. Geochemistry, Geophys. Geosystems 13 (12).

Hartmann, W.K., Thorsteinsson, T., Sigurdsson, F., 2003. Martian hillside gullies and Icelandic analogs. Icarus 162 (2), 259-277.

Hayas, A., Vanwalleghem, T., Laguna, A., Peña Acevedo, A., Giráldez, J.V., 2017a. Reconstructing Long-Term Gully Dynamics in Mediterranean Agricultural Areas.

Hayas, A., Poesen, J., Vanwalleghem, T., 2017b. Rainfall and vegetation effects on temporal variation of topographic thresholds for gully initiation in Mediterranean cropland and olive groves. Land Degrad. Dev. 28 (8), 2540-2552.

Hayas, A., Peña, A., Vanwalleghem, T., 2019. Predicting gully width and widening rates from upstream contribution area and rainfall: a case study in SW Spain. Geomorphology 341, 130-139.

Haylock, M.R., Hofstra, N., Klein Tank, A.M.G., Klok, E.J., Jones, P.D., New, M., 2008. A European daily high-resolution gridded data set of surface temperature and precipitation for 1950-2006. J. Geophys. Res. Atmosph. 113 (D20).

Heine, K., Niller, H.-P., 2003. Human and climate impacts on the Holocene landscape development in southern Germany. Geogr. Pol. 76, 109-122.

Heininger, P., Keller, I., Quick, I., Schwartz, R., Vollmer, S., 2015. Sediment management on river-basinscale: the river Elbe. In: Sediment Matters. Springer, Cham, pp. 201-247.

Hengl, T., de Jesus, J.M., Heuvelink, G.B., Gonzalez, M.R., Kilibarda, M., Blagotić, A., Guevara, M.A., 2017. SoilGrids250m: Global gridded soil information based on machine learning. PLoS One 12 (2).

Höfle, B., Rutzinger, M., 2011. Topographic airborne LiDAR in geomorphology: a technological perspective. Zeitschrift Geomorphol. Suppl. Issues 55 (2), 1-29.

Hong, Y., Adler, R.F., Hossain, F., Curtis, S., Huffman, G.J., 2007. A first approach to global runoff simulation using satellite rainfall estimation. Water Resour. Res. 43 (8).

Hopp, L., McDonnell, J.J., 2009. Connectivity at the hillslope scale: Identifying interactions between storm size, bedrock permeability, slope angle and soil depth. J. Hydrol. 376 (3-4), 378-391.

Hosseinalizadeh, M., Kariminejad, N., Chen, W., Pourghasemi, H.R., Alinejad, M., Behbahani, A.M., Tiefenbacher, J.P., 2019. Gully headcut susceptibility modeling using functional trees, naïve Bayes tree, and random forest models. Geoderma 342, $1-11$. 
Hou, A.Y., Skofronick-Jackson, G., Kummerow, C.D., Shepherd, J.M., 2008. Global precipitation measurement. In: Precipitation: Advances in Measurement, Estimation and Prediction. Springer, Berlin, Heidelberg, pp. 131-169.

Hou, A.Y., Kakar, R.K., Neeck, S., Azarbarzin, A.A., Kummerow, C.D., Kojima, M., Iguchi, T., 2014. The global precipitation measurement mission. Bull. Am. Meteorol. Soc. 95 (5), 701-722.

Howe, G.M., 1955. A South Wales thunderstorm. Meteorol. Mag. 84, 281-286.

Huffman, G.J., Bolvin, D.T., 2013. Version 1.2 GPCP one degree daily precipitation data set documentation. NASA Godd. Space Flight Cent. Rep.

Huffman, G.J., Bolvin, D.T., Nelkin, E.J., Wolff, D.B., Adler, R.F., Gu, G., Stocker, E.F., 2007. The TRMM multisatellite precipitation analysis (TMPA): Quasi-global, multiyear, combined-sensor precipitation estimates at fine scales. J. Hydrometeorol. 8 (1), 38-55.

Huffman, G.J., Bolvin, D.T., Braithwaite, D., Hsu, K., Joyce, R., Xie, P., Yoo, S.H., 2015. NASA global precipitation measurement (GPM) integrated multi-satellite retrievals for GPM (IMERG). Algorithm Theor. Basis Doc. (ATBD) Version 4, 26.

Hughes, A.O., Prosser, I.P., 2012. Gully erosion prediction across a large region: Murray-Darling Basin, Australia. Soil Res. 50 (4), 267-277.

Ichim, I., Mihaiu, G., Surdeanu, V., Radoane, M., Radoane, N., 1990. Gully erosion on agricultural lands in Romania. In Soil erosion on agricultural land. In: Proceedings of a Workshop Sponsored by the British Geomorphological Research Group, Coventry, UK, January 1989. John Wiley \& Sons Ltd, pp. 55-67.

Imeson, A.C., Kwaad, F.J.P.M., 1980. Gully types and gully prediction. Geogr. Tijdschr. 14 (5), 430-441.

Ionita, I., 2003. Hydraulic efficiency of the discontinuous gullies. Catena 50 (2-4), 369-379.

Ionita, I., 2006. Gully development in the Moldavian Plateau of Romania. Catena 68 (2-3), 133-140.

Ionita, I., Fullen, M.A., Zgłobicki, W., Poesen, J., 2015a. Gully erosion as a natural and human-induced hazard. Nat. Haz. Vol. 79, 1-5.

Ionita, I., Niacsu, L., Petrovici, G., Blebea-Apostu, A.M., 2015b. Gully development in eastern Romania: a case study from Falciu Hills. Nat. Hazards 79 (1), 113-138.

Istanbulluoglu, E., Tarboton, D.G., Pack, R.T., Luce, C., 2003. A sediment transport model for incision of gullies on steep topography. Water Resour. Res. 39 (4).

Istanbulluoglu, E., Bras, R.L., Flores-Cervantes, H., Tucker, G.E., 2005. Implications of bank failures and fluvial erosion for gully development: Field observations and modeling. J. Geophys. Res. Earth Surf. 110 (F1).

Istanbulluoglu, E., Yetemen, O., Vivoni, E.R., Gutiérrez-Jurado, H.A., Bras, R.L., 2008. Eco-geomorphic implications of hillslope aspect: Inferences from analysis of landscape morphology in Central New Mexico. Geophys. Res. Lett. 35 (14).

Jakab, G., Madarasz, B., Örsi, A., Szalai, Z., Kertész, A., 2011. Gullies of two Hungarian regions - a case study. Hungar. Geogr. Bull. 60 (4), 325-342.

James, L.A., Watson, D.G., Hansen, W.F., 2007. Using LiDAR data to map gullies and headwater streams under forest canopy: South Carolina, USA. Catena 71 (1), 132-144.

Janicki, G., 2014. Transformation of upland wash slope-a case study from the Lublin Upland (SE Poland). In: Annales Universitatis Mariae Curie-Sklodowska, 69. De Gruyter Open Sp. z oo, p. 31 no. 1.

Janicki, G., Zgłobicki, W., 1998. Geomorfologiczne skutki ulewy (z 16.09. 1995 r.) w okolicy Garbowa na Wyżynie Lubelskiej. In: Annales UMCS, sec. B, 53, pp. 109-129.

Jetten, V., Govers, G., Hessel, R., 2003. Erosion models: quality of spatial predictions. Hydrol. Process. 17 (5), 887-900.

Joyce, R.J., Janowiak, J.E., Arkin, P.A., Xie, P., 2004. CMORPH: a method that produces global precipitation estimates from passive microwave and infrared data at high spatial and temporal resolution. J. Hydrometeorol. 5 (3), 487-503.

Józefaciuk, C., Józefaciuk, A., 1983. Struktura przestrzenna erozji wąwozowej w Polsce. Pam. Puł 79.

Jurchescu, M., Grecu, F., 2015. Modelling the occurrence of gullies at two spatial scales in the Olteţ Drainage Basin (Romania). Nat. Hazards 79 (1), 255-289.

Kalnay, E., Kanamitsu, M., Kistler, R., Collins, W., Deaven, D., Gandin, L., Joseph, D., 1996. The NCEP/NCAR 40-year reanalysis project. Bull. Am. Meteorol. Soc. 77 (3), 437-471.

Kanamitsu, M., Ebisuzaki, W., Woolen, J., Yang, S.-K., Hnilo, J.J., Fiorino, M., Potter, G. L., 2002. NCEP-DOE AMIP-II Reanalysis (R-2). Bull. Am. Meteorol. Soc. 83 (11), 1631-1643.

Karydas, C., Panagos, P., 2020. Towards an assessment of the ephemeral gully erosion potential in Greece using Google Earth. Water 12 (2), 603.

Keesstra, S.D., Bouma, J., Wallinga, J., Tittonell, P., Smith, P., Cerdà, A., Bardgett, R.D., 2016. The Significance of Soils and Soil Science towards Realization of the United Nations Sustainable Development Goals (Soil).

Kertész, Á., Gergely, J., 2011. Gully erosion in Hungary, review and case study. Procedia Soc. Behav. Sci. 19, 693-701.

Kertész, Á., Křeček, J., 2019. Landscape degradation in the world and in Hungary. Hungar. Geogr. Bull. 68 (3), 201-221.

Kheir, R.B., Wilson, J., Deng, Y., 2007. Use of terrain variables for mapping gully erosion susceptibility in Lebanon. Earth Surf. Proc. Landf. J. Br. Geomorphol. Res. Group 32 (12), 1770-1782.

Kheir, R.B., Chorowicz, J., Abdallah, C., Dhont, D., 2008. Soil and bedrock distribution estimated from gully form and frequency: a GIS-based decision-tree model for Lebanon. Geomorphology 93 (3-4), 482-492.

Kirkby, M.J., Bull, L.J., Poesen, J., Nachtergaele, J., Vandekerckhove, L., 2003. Observed and modelled distributions of channel and gully heads-with examples from SE Spain and Belgium. Catena 50 (2-4), 415-434.

Knapen, A., Poesen, J., 2010. Soil erosion resistance effects on rill and gully initiation points and dimensions. Earth Surf. Proc. Landf. J. Br. Geomorphol. Res. Group 35 (2), 217-228.
Knapen, A., Poesen, J., Govers, G., Gyssels, G., Nachtergaele, J., 2007. Resistance of soils to concentrated flow erosion: a review. Earth Sci. Rev. 80 (1-2), 75-109.

Knight, J., Spencer, J., Brooks, A., Phinn, S., 2007. Large-area, high-resolution remote sensing based mapping of alluvial gully erosion in Australia's tropical rivers. In: Proceedings of the 5th Australian Stream Management Conference. Charles Sturt University, pp. 199-204.

Koci, J., Jarihani, B., Leon, J.X., Sidle, R., Wilkinson, S., Bartley, R., 2017. Assessment of UAV and ground-based structure from motion with multi-view stereo

photogrammetry in a gullied savanna catchment. ISPRS Int. J. Geo Inf. 6 (11), 328.

Koci, J., Wilkinson, S., Henderson, A., Hawdon, A., Bartley, R., Goodwin, N., 2021. Rehabilitation effects on gully sediment yields and vegetation in a savanna rangeland. Earth Surf. Process. Landf. https://doi.org/10.1002/esp.5076 (in press).

Kociuba, W., Janicki, G., Rodzik, J., Stępniewski, K., 2015. Comparison of volumetric and remote sensing methods (TLS) for assessing the development of a permanent forested loess gully. Nat. Hazards 79 (1), 139-158.

Krieger, G., Moreira, A., Fiedler, H., Hajnsek, I., Werner, M., Younis, M., Zink, M., 2007. TanDEM-X: a satellite formation for high-resolution SAR interferometry. IEEE Trans. Geosci. Remote Sens. 45 (11), 3317-3341.

Kroon, F.J., Kuhnert, P.M., Henderson, B.L., Wilkinson, S.N., Kinsey-Henderson, A., Abbott, B., Turner, R.D., 2012. River loads of suspended solids, nitrogen, phosphorus and herbicides delivered to the Great Barrier Reef lagoon. Mar. Pollut. Bull. 65 (4-9), $167-181$.

Kroon, F.J., Thorburn, P., Schaffelke, B., Whitten, S., 2016. Towards protecting the Great Barrier Reef from land-based pollution. Glob. Chang. Biol. 22 (6), 1985-2002.

Kropacek, J., Schillaci, C., Salvini, R., Marker, M., 2016. Assessment of gully erosion in the Upper Awash, Central Ethiopian highlands based on a comparison of archived aerial photographs and very high resolution satellite images. Geogr. Fis. Din. Quat. 39, 161-170.

Kuhnert, P.M., Henderson, A.K., Bartley, R., Herr, A., 2010. Incorporating uncertainty in gully erosion calculations using the random forests modelling approach. Environmetrics 21 (5), 493-509.

Lanckriet, S., Frankl, A., Mesfin, G., Descheemaeker, K., Nyssen, J., 2015. Gully cut? And? Fill cycles as related to agro? Management: a historical curve number simulation in the Tigray Highlands. Earth Surf. Process. Landf. 40 (6), 796-808.

Langohr, R., Sanders, J., 1985. The Belgian loess belt in the last 20000 years: evolution of soils and relief in the Zonien Forest. In: Quaternary research association. Meeting, pp. 359-371.

Lesschen, J.P., Kok, K., Verburg, P.H., Cammeraat, L.H., 2007. Identification of vulnerable areas for gully erosion under different scenarios of land abandonment in Southeast Spain. Catena 71 (1), 110-121.

Lewiński, S., Malinowski, R., Rybicki, M., Gromny, E., Nowakowski, A., Jenerowicz, M., Krupiński, M., Krupiński, M., Krätzschmar, E., Günther, S., 2019. Atomatic Land Cover Classification of Europe with Sentinel-2 Imagery, 2019 Living Planet Symposium, 13-17 May 2019, Milan, Italy.

Li, Z., Fang, H., 2016. Impacts of climate change on water erosion: a review. Earth Sci. Rev. 163, 94-117.

Li, Z., Zhang, Y., Zhu, Q., He, Y., Yao, W., 2015. Assessment of bank gully development and vegetation coverage on the Chinese Loess Plateau. Geomorphology 228, 462-469.

Litvin, L.F., Zorina, Y.F., Sidorchuk, A.Y., Chernov, A.V., Golosov, V.N., 2003. Erosion and sedimentation on the Russian Plain, part 1: contemporary processes. Hydrol. Process. 17 (16), 3335-3346.

Lohani, B., Ghosh, S., Dashora, A., 2018. A review of standards for airborne LiDAR data acquisition, processing, QA/QC, and delivery. In: Geospatial Infrastructure, Applications and Technologies: India Case Studies. Springer, Singapore, pp. 305-312.

Lucà, F., Conforti, M., Robustelli, G., 2011. Comparison of GIS-based gullying susceptibility mapping using bivariate and multivariate statistics: Northern Calabria, South Italy. Geomorphology 134 (3-4), 297-308.

Lucas-Borja, M.E., Zema, D.A., Guzman, M.D.H., Yang, Y., Hernández, A.C., Xiangzhou, X., Cerdá, A., 2018. Exploring the influence of vegetation cover, sediment storage capacity and channel dimensions on stone check dam conditions and effectiveness in a large regulated river in México. Ecol. Eng. 122, 39-47.

Lucía, A., Laronne, J.B., Martín-Duque, J.F., 2011. Geodynamic processes on sandy slope gullies in Central Spain field observations, methods and measurements in a singular system. Geodin. Acta 24 (2), 61-79.

MacNeil, M.A., Mellin, C., Matthews, S., Wolff, N.H., McClanahan, T.R., Devlin, M., Graham, N.A., 2019. Water quality mediates resilience on the Great Barrier Reef. Nat. Ecol. Evol. 3 (4), 620-627.

Maerker, M., Pelacani, S., Schröder, B., 2011. A functional entity approach to predict soil erosion processes in a small Plio-Pleistocene Mediterranean catchment in Northern Chianti, Italy. Geomorphology 125 (4), 530-540.

Maerker, M., Schillaci, C., Melis, R.T., Kropáček, J., Bosino, A., Vilímek, V., Mussi, M., 2019. Geomorphological processes, forms and features in the surroundings of the Melka Kunture Palaeolithic site, Ethiopia. J. Maps 15 (2), 797-806.

Maerker, M., Bosino, A., Scopesi, C., Giordani, P., Firpo, M., Rellini, I., 2020. Assessment of calanchi and rill-interrill erosion susceptibility in northern Liguria, Italy: a case study using a probabilistic modelling framework. Geoderma 371, 114367.

Maetens, W., Vanmaercke, M., Poesen, J., Jankauskas, B., Jankauskiene, G., Ionita, I., 2012a. Effects of land use on annual runoff and soil loss in Europe and the Mediterranean: a meta-analysis of plot data. Prog. Phys. Geogr. 36 (5), 599-653.

Maetens, W., Poesen, J., Vanmaercke, M., 2012b. How effective are soil conservation techniques in reducing plot runoff and soil loss in Europe and the Mediterranean? Earth Sci. Rev. 115 (1-2), 21-36.

Makanzu Imwangana, F., Vandecasteele, I., Trefois, P., Ozer, P., Moeyersons, J., 2015. The origin and control of mega-gullies in Kinshasa (DR Congo). Catena 125, 38-49. 
Malik, I., 2008. Dating of small gully formation and establishing erosion rates in old gullies under forest by means of anatomical changes in exposed tree roots (Southern Poland). Geomorphology 93 (3-4), 421-436.

Malinov, I., Ilieva, D., 2017. Gully and Rill Erosion in the National Park "Central Balkan". Bulgar. J. Agric. Sci. 23 (2), 238-241.

Maltsev, K.A., Yermolaev, O.P., 2019. Potential soil loss from erosion on arable lands in the European part of Russia. Eurasian Soil Sci. 52 (12), 1588-1597.

Mararakanye, N., Le Roux, J.J., 2012. Gully location mapping at a national scale for South Africa. S. Afr. Geogr. J. 94 (2), 208-218.

Marden, M., Fuller, I.C., Herzig, A., Betts, H.D., 2018. Badass gullies: Fluvio-massmovement gully complexes in New Zealand's East Coast region, and potential for remediation. Geomorphology 307, 12-23.

Martineli Costa, F., Bacellar, L.D.A.P., 2007. Analysis of the influence of gully erosion in the flow pattern of catchment streams, Southeastern Brazil. Catena 69 (3), 230-238.

Martınez-Casasnovas, J.A., Ramos, M.C., Ribes-Dasi, M., 2002. Soil erosion caused by extreme rainfall events: mapping and quantification in agricultural plots from very detailed digital elevation models. Geoderma 105 (1-2), 125-140.

Martínez-Casasnovas, J.A., Antón-Fernández, C., Ramos, M.C., 2003. Sediment production in large gullies of the Mediterranean area (NE Spain) from highresolution digital elevation models and geographical information systems analysis. Earth Surf. Proc. Landf. J. Br. Geomorphol. Res. Group 28 (5), 443-456.

Martinez-Casasnovas, J.A., Ramos, M.C., Poesen, J., 2004. Assessment of sidewall erosion in large gullies using multi-temporal DEMs and logistic regression analysis. Geomorphology 58 (1-4), 305-321.

Martín-Moreno, C., Hijano, C.F., Duque, J.M., Martín, J.G., Alonso, I.Z., Laronne, J.B., 2014. The Ribagorda sand gully (east-Central Spain): Sediment yield and humaninduced origin. Geomorphology 224, 122-138.

Martins, B., Lourenço, L., Lima, H.R., 2017. Ação antrópica e risco de ravinamento: o exemplo da ravina do Corgo (Rio Alva). Territorium 24, 221-234.

Martins, B., Meira-Castro, A., Nunes, A., Lourenço, L., 2020. The development of gullies in a Mediterranean environment: the example of the Corgo gully (Central Portugal). Energy Rep. 6, 794-799.

Maruszczak, H., Trembaczowski, J., 1956. Geomorfologiczne skutki gwałtownej ulewy w Piaskach Szlacheckich. Ann. UMCS B 11, 129-160.

Marzolff, I., Poesen, J., 2009. The potential of 3D gully monitoring with GIS using highresolution aerial photography and a digital photogrammetry system. Geomorphology 111 (1-2), 48-60.

Marzolff, I., Ries, J.B., Poesen, J., 2011. Short-term versus medium-term monitoring for detecting gully-erosion variability in a Mediterranean environment. Earth Surf. Process. Landf. 36 (12), 1604-1623.

Mathys, N., Brochot, S., Meunier, M., Richard, D., 2003. Erosion quantification in the small marly experimental catchments of Draix (Alpes de Haute Provence, France). Calibration of the ETC rainfall-runoff-erosion model. Catena 50 (2-4), 527-548.

Maugnard, A., Van Dyck, S., Bielders, C.L., 2014a. Assessing the regional and temporal variability of the topographic threshold for ephemeral gully initiation using quantile regression in Wallonia (Belgium). Geomorphology 206, 165-177.

Maugnard, A., Cordonnier, H., Degre, A., Demarcin, P., Pineux, N., Bielders, C.L., 2014b. Uncertainty assessment of ephemeral gully identification, characteristics and topographic threshold when using aerial photographs in agricultural settings. Earth Surf. Process. Landf. 39 (10), 1319-1330.

Medvedeva, R.A., Golosov, V.N., Ermolaev, O.P., 2018. Spatio-temporal assessment of gully erosion in the zone of intensive agriculture in the European part of Russia. Geogr. Nat. Resour. 39, 204-211.

Menéndez-Duarte, R., Marquínez, J., Fernández-Menéndez, S., Santos, R., 2007. Incised channels and gully erosion in Northern Iberian Peninsula: Controls and geomorphic setting. Catena 71 (2), 267-278.

Merritt, W.S., Letcher, R.A., Jakeman, A.J., 2003. A review of erosion and sediment transport models. Environ. Model. Softw. 18 (8-9), 761-799.

Minasny, B., McBratney, A.B., 2006. A conditioned Latin hypercube method for sampling in the presence of ancillary information. Comput. Geosci. 32 (9), 1378-1388.

Mircea, S., 2011. Impactul ravenării asupra mediului în B.H. In: Slănic/Buzău (Impact of Gullying to Environment in the Slanicul Buzaului Catchment). Editura BREN, București. ISBN 978-606-610-008-3.

Mitusov, A.V., Burian, L., Khrisanov, V.R., 2017. Distribution of local landforms at head and end points of gullies on different grid spacing. Catena 159, 159-170.

Moldenhauer, K.M., Heinrich, J., Vater, A., 2010. Causes and history of multiple soil erosion processes in the northern Odenwald uplands. Erde 141 (3), 171-186.

Molina, A., Govers, G., Cisneros, F., Vanacker, V., 2009. Vegetation and topographic controls on sediment deposition and storage on gully beds in a degraded mountain area. Earth Surf. Process. Landf. 34 (6), 755-767.

Momm, H.G., Bingner, R.L., Wells, R.R., Wilcox, D., 2012. AGNPS GIS-based tool for watershed-scale identification and mapping of cropland potential ephemeral gullies. Appl. Eng. Agric. 28 (1), 17-29.

Momm, H.G., Bingner, R.L., Wells, R.R., Rigby, J.R., Dabney, S.M., 2013. Effect of topographic characteristics on compound topographic index for identification of gully channel initiation locations. Trans. ASABE 56 (2), 523-537.

Momm, H.G., Wells, R.R., Bingner, R.L., 2015. GIS technology for spatiotemporal measurements of gully channel width evolution. Nat. Hazards 79 (1), 97-112.

Mondal, A., Khare, D., Kundu, S., Mukherjee, S., Mukhopadhyay, A., Mondal, S., 2017. Uncertainty of soil erosion modelling using open source high resolution and aggregated DEMs. Geosci. Front. 8 (3), 425-436.

Monsieurs, E., Poesen, J., Dessie, M., Adgo, E., Verhoest, N.E., Deckers, J., Nyssen, J., 2015. Effects of drainage ditches and stone bunds on topographical thresholds for gully head development in North Ethiopia. Geomorphology 234, 193-203.
Monsieurs, E., Kirschbaum, D.B., Tan, J., Maki Mateso, J.C., Jacobs, L., Plisnier, P.D., Ganza, G.B., 2018. Evaluating TMPA rainfall over the sparsely gauged East African Rift. J. Hydrometeorol. 19 (9), 1507-1528.

Montanarella, L., Panagos, P., 2021. The relevance of sustainable soil management within the European Green Deal. Land Use Policy 100, 104950.

Montanarella, L., Pennock, D.J., McKenzie, N., Badraou, M., Chude, V., Baptista, I., Hong, S.Y., 2016. World's Soils Are under Threat (Soil).

Montgomery, D.R., 2007. Soil erosion and agricultural sustainability. Proc. Natl. Acad. Sci. 104 (33), 13268-13272.

Montgomery, D.R., Dietrich, W.E., 1994. A physically based model for the topographic control on shallow landsliding. Water Resour. Res. 30 (4), 1153-1171.

Moore, I.D., Burch, G.J., Mackenzie, D.H., 1988. Topographic effects on the distribution of surface soil water and the location of ephemeral gullies. Trans. ASAE 31 (4), 1098-1107.

Morris, F.G., 1942. Severe erosion near Blaydon, county Durham. Geogr. J. 100 (5/6), $257-261$.

Motoc, M., 1983. Ritmul mediu de degradare erozionala a solului in RS Romania. Bul. Inf. ASA 13.

Motoc, M., 1984. Sediment Yield by Sources in the Streams of Romania [Soil Erosion] (Buletinul informativ al Academiei de Stiinte Agricole si Silvice).

Nachtergaele, J., Poesen, J., 1999. Assessment of soil losses by ephemeral gully erosion using high-altitude (stereo) aerial photographs. Earth Surf. Proc. Landf. J. Br. Geomorphol. Res. Group 24 (8), 693-706.

Nachtergaele, J., Poesen, J., 2002. Spatial and temporal variations in resistance of loessderived soils to ephemeral gully erosion. Eur. J. Soil Sci. 53 (3), 449-463.

Nachtergaele, J., Poesen, J., Vandekerckhove, L., Oostwoud Wijdenes, D., Roxo, M., 2001a. Testing the ephemeral gully erosion model (EGEM) for two Mediterranean environments. Earth Surf. Proc. Landf. J. Br. Geomorphol. Res. Group 26 (1), 17-30.

Nachtergaele, J., Poesen, J., Steegen, A., Takken, I., Beuselinck, L., Vandekerckhove, L., Govers, G., 2001b. The value of a physically based model versus an empirical approach in the prediction of ephemeral gully erosion for loess-derived soils. Geomorphology 40 (3-4), 237-252.

Nachtergaele, J., Poesen, J., Sidorchuk, A., Torri, D., 2002a. Prediction of concentrated flow width in ephemeral gully channels. Hydrol. Process. 16 (10), 1935-1953.

Nachtergaele, J., Poesen, J., Wijdenes, D.O., Vandekerckhove, L., 2002b. Medium-term evolution of a gully developed in a loess-derived soil. Geomorphology 46 (3-4), 223-239.

Nadal-Romero, E., Revuelto, J., Errea, P., López-Moreno, J.I., 2015. The application of terrestrial laser scanner and SfM photogrammetry in measuring erosion and deposition processes in two opposite slopes in a humid badlands area (central Spanish Pyrenees). Soil 1 (2), 561.

Nearing, M.A., Pruski, F.F., O'neal, M.R., 2004. Expected climate change impacts on soil erosion rates: a review. J. Soil Water Conserv. 59 (1), 43-50.

New, M., Hulme, M., Jones, P., 2000. Representing twentieth-century space-time climate variability. Part II: development of 1901-96 monthly grids of terrestrial surface climate. J. Clim. 13, 2217-2238.

Nguyen, P., Shearer, E.J., Tran, H., Ombadi, M., Hayatbini, N., Palacios, T., Kuligowski, B., 2019. The CHRS data portal, an easily accessible public repository for PERSIANN global satellite precipitation data. Sci. Data 6 (1), 1-10.

Niacsu, L., Ionita, I., 2011. Gully erosion in the Pereschiv catchment of Eastern Romania. Landform Analys. 17, 135-137.

Nicu, I.C., 2018. Is overgrazing really influencing soil erosion? Water 10 (8), 1077.

Nitrate Directive (91/676/EEC), 1991. European Commission, Nitrates Directive. URL: https://ec.europa.eu/environment/water/water-nitrates/report.html.

Nogueras, P., Burjachs, F., Gallart, F., Puigdefàbregas, J., 2000. Recent gully erosion in the El Cautivo badlands (Tabernas, SE Spain). Catena 40 (2), 203-215.

Nordström, K., 1984. The Lagnäset Gully at the Öreälven River, northern Sweden. Geol. Fören. Stockholm Förhandlingar 106 (2), 179-184.

Nosko, R., Maliariková, M., Brziak, A., Kubán̆, M., 2019. Formation of Gully Erosion in the Myjava Region. Slovak J. Civil Eng. 27 (3), 63-72.

Nyssen, J., Poesen, J., Veyret-Picot, M., Moeyersons, J., Haile, M., Deckers, J., Govers, G., 2006. Assessment of gully erosion rates through interviews and measurements: a case study from northern Ethiopia. Earth Surf. Process. Landf. 31 (2), 167-185.

Ollobarren Del Barrio, P., Campo-Bescós, M.A., Giménez, R., Casalí, J., 2018. Assessment of soil factors controlling ephemeral gully erosion on agricultural fields. Earth Surf. Process. Landf. 43 (9), 1993-2008.

Oostwoud Wijdenes, D.J., Poesen, J., Vandekerckhove, L., Nachtergaele, J., De Baerdemaeker, J., 1999. Gully-head morphology and implications for gully development on abandoned fields in a semi-arid environment, Sierra de Gata, Southeast Spain. Earth Surf. Proc. Landf. J. Br. Geomorphol. Res. Group 24 (7), 585-603.

Oostwoud Wijdenes, D.J., Poesen, J., Vandekerckhove, L., Ghesquiere, M., 2000. Spatial distribution of gully head activity and sediment supply along an ephemeral channel in a Mediterranean environment. Catena 39 (3), 147-167.

Orgiazzi, A., Ballabio, C., Panagos, P., Jones, A., Fernández-Ugalde, O., 2018. LUCAS Soil, the largest expandable soil dataset for Europe: a review. Eur. J. Soil Sci. 69 (1), $140-153$.

Owens, P.N., Batalla, R.J., Collins, A.J., Gomez, B., Hicks, D.M., Horowitz, A.J., Petticrew, E.L., 2005. Fine-grained sediment in river systems: environmental significance and management issues. River Res. Appl. 21 (7), 693-717.

Øygarden, L., 2003. Rill and gully development during an extreme winter runoff event in Norway. Catena 50 (2-4), 217-242.

Panagos, P., Katsoyiannis, A., 2019. Soil erosion modelling: the new challenges as the result of policy developments in Europe. Environ. Res. 172, 470-474. 
Panagos, P., Van Liedekerke, M., Jones, A., Montanarella, L., 2012. European soil data centre: response to European policy support and public data requirements. Land Use Policy 29 (2), 329-338.

Panagos, P., Meusburger, K., Ballabio, C., Borrelli, P., Alewell, C., 2014. Soil erodibility in Europe: a high-resolution dataset based on LUCAS. Sci. Total Environ. 479, 189-200.

Panagos, P., Borrelli, P., Poesen, J., Ballabio, C., Lugato, E., Meusburger, K., Alewell, C., 2015a. The new assessment of soil loss by water erosion in Europe. Environ. Sci. Pol. 54, 438-447.

Panagos, P., Borrelli, P., Robinson, D.A., 2015b. Tackling soil loss across Europe. Nature 526 (7572), p 195.

Panagos, P., Borrelli, P., Meusburger, K., Alewell, C., Lugato, E., Montanarella, L., 2015c. Estimating the soil erosion cover-management factor at the European scale. Land Use Policy 48, 38-50.

Panagos, P., Ballabio, C., Borrelli, P., Meusburger, K., Klik, A., Rousseva, S., Tadić, M.P., Michaelides, S., Hrabalíková, M., Olsen, P., Aalto, J., 2015d. Rainfall erosivity in Europe. Sci. Total Environ. 511, 801-814.

Panagos, P., Borrelli, P., Meusburger, K., van der Zanden, E.H., Poesen, J., Alewell, C., 2015e. Modelling the effect of support practices (P-factor) on the reduction of soil erosion by water at European scale. Environ. Sci. Pol. 51, 23-34.

Panagos, P., Ballabio, C., Meusburger, K., Spinoni, J., Alewell, C., Borrelli, P., 2017. Towards estimates of future rainfall erosivity in Europe based on REDES and WorldClim datasets. J. Hydrol. 548, 251-262.

Papčo, P., 2011. Permanent gullies in the Nitra Hill Land, Slovakia: about the cause of gully formation. Landform Analys. 17, 139-144.

Patault, E., Alary, C., Franke, C., Gauthier, A., Abriak, N.E., 2019. Assessing temporal variability and controlling factors of the sediment budget of a small agricultural catchment in Northern France (the Pommeroye). Heliyon 5 (3), e01407.

Pederson, J.L., Petersen, P.A., Dierker, J.L., 2006. Gullying and erosion control at archaeological sites in Grand Canyon, Arizona. Earth Surf. Proc. Landf. J. Br. Geomorphol. Res. Group 31 (4), 507-525.

Pelletier, J.D., 2012. A spatially distributed model for the long-term suspended sediment discharge and delivery ratio of drainage basins. J. Geophys. Res. Earth Surf. 117 (F2).

Pennock, D., 2019. Soil Erosion: The Greatest Challenge for Sustainable Soil Management. FAO-Food and Agriculture Organization of the United Nations, Rome.

Perroy, R.L., Bookhagen, B., Asner, G.P., Chadwick, O.A., 2010. Comparison of gully erosion estimates using airborne and ground-based LiDAR on Santa Cruz Island, California. Geomorphology 118 (3-4), 288-300.

Peterson, T.C., Vose, R.S., 1997. An overview of the global historical climatology network temperature database. Bull. Am. Meteorol. Soc. 78 (12), 2837-2849.

Piccarreta, M., Capolongo, D., Miccoli, M.N., Bentivenga, M., 2012. Global change and long-term gully sediment production dynamics in Basilicata, southern Italy. Environ. Earth Sci. 67 (6), 1619-1630.

Platoncheva, E., Yermolaev, O., Essuman-Quainoo, B., 2020. Spatial-temporal dynamics of the ephemeral gully belt on the plowed slopes of river basins in natural and anthropogenic landscapes of the east of the russian plain. Geosciences 10 (5), 167.

Poesen, J., 1989. Conditions for gully formation in the Belgian loam belt and some ways to control them. In: Soil Erosion Protection Measures in Europe. Proc. EC workshop. Freising, 1988, pp. 39-52.

Poesen, J., 2018. Soil erosion in the Anthropocene: Research needs. Earth Surf. Process. Landf. 43 (1), 64-84.

Poesen, J., Vandaele, K., Van Wesemael, B., 1996. Contribution of gully erosion to sediment production. In: Erosion and Sediment Yield: Global and Regional Perspectives: Proceedings of an International Symposium Held at Exeter, UK, from 15 to 19 July 1996, 236. IAHS, p. 251.

Poesen, J., de Luna, E., Franca, A., Nachtergaele, J., Govers, G., 1999. Concentrated flow erosion rates as affected by rock fragment cover and initial soil moisture content. Catena 36, 315-329.

Poesen, J., Vandekerckhove, L., Nachtergaele, J., Oostwoud Wijdenes, D., Verstraeten, G., van Wesemael, B., 2002. Gully erosion in dryland environments. In: Bull, L.J., Kirkby, M.J. (Eds.), Dryland Rivers: Hydrology and Geomorphology of Semi-Arid Channels. Wiley, Chichester, UK, pp. 229-262.

Poesen, J., Nachtergaele, J., Verstraeten, G., Valentin, C., 2003. Gully erosion and environmental change: importance and research needs. Catena 50 (2-4), 91-133.

Poesen, J., Vanwalleghem, T., de Vente, J., Knapen, A., Verstraeten, G., MartínezCasasnovas, J.A., 2006. Gully erosion in Europe. Soil Eros. Europe 515-536.

Poesen, J., Torri, D.B., Vanwalleghem, T., 2011. Gully erosion: procedures to adopt when modelling soil erosion in landscapes affected by gullying. Handbook Erosion Modell 360-386.

Polade, S.D., Pierce, D.W., Cayan, D.R., Gershunov, A., Dettinger, M.D., 2014. The key role of dry days in changing regional climate and precipitation regimes. Sci. Rep. 4, 4364.

Ponce, V.M., Hawkins, R.H., 1996. Runoff curve number: has it reached maturity? J. Hydrol. Eng. 1 (1), 11-19.

Portenga, E.W., Bishop, P., Rood, D.H., Bierman, P.R., 2017. Combining bulk sediment OSL and meteoric $10 \mathrm{Be}$ fingerprinting techniques to identify gully initiation sites and erosion depths. J. Geophys. Res. Earth Surf. 122 (2), 513-527.

Pourghasemi, H.R., Yousefi, S., Kornejady, A., Cerdà, A., 2017. Performance assessment of individual and ensemble data-mining techniques for gully erosion modeling. Sci. Total Environ. 609, 764-775.

Prosser, I.P., Abernethy, B., 1996. Predicting the topographic limits to a gully network using a digital terrain model and process thresholds. Water Resour. Res. 32 (7), 2289-2298.

Prosser, I.P., Slade, C.J., 1994. Gully formation and the role of valley-floor vegetation, southeastern Australia. Geology 22 (12), 1127-1130.
Pulice, I., Di Leo, P., Robustelli, G., Scarciglia, F., Cavalcante, F., Belviso, C., 2013. Control of climate and local topography on dynamic evolution of badland from southern Italy (Calabria). Catena 109, 83-95.

Purinton, B., Bookhagen, B., 2017. Validation of digital elevation models (DEMs) and comparison of geomorphic metrics on the southern Central Andean Plateau. Earth Surf. Dynam. 5 (2).

Rabus, B., Eineder, M., Roth, A., Bamler, R., 2003. The shuttle radar topography mission - a new class of digital elevation models acquired by spaceborne radar. ISPRS J. Photogramm. Remote Sens. 57 (4), 241-262.

Radoane, M., Radoane, N., 2017. Gully erosion. In: Radoane, M., Vespremeanu-Stroe, A. (Eds.), Landform Dynamics and Evolution in Romania. Springer Geography, pp. 371-396.

Radoane, M., Ichim, I., Radoane, N., 1995. Gully distribution and development in Moldavia, Romania. Catena 24 (2), 127-146.

Rahmati, O., Haghizadeh, A., Pourghasemi, H.R., Noormohamadi, F., 2016. Gully erosion susceptibility mapping: the role of GIS-based bivariate statistical models and their comparison. Nat. Hazards 82 (2), 1231-1258.

Rahmati, O., Tahmasebipour, N., Haghizadeh, A., Pourghasemi, H.R., Feizizadeh, B., 2017. Evaluating the influence of geo-environmental factors on gully erosion in a semi-arid region of Iran: an integrated framework. Sci. Total Environ. 579, 913-927.

Reed, A.H., 1979. Accelerated erosion of arable soils in the United Kingdom by rainfall and run-off. Outlook Agric. 10 (1), 41-48.

Reichle, R.H., Koster, R.D., De Lannoy, G.J., Forman, B.A., Liu, Q., Mahanama, S.P., Touré, A., 2011. Assessment and enhancement of MERRA land surface hydrology estimates. J. Clim. 24 (24), 6322-6338.

Renard, K.G., 1997. Predicting Soil Erosion by Water: A Guide to Conservation Planning with the Revised Universal Soil Loss Equation (RUSLE). United States Government Printing.

Rengers, F.K., Tucker, G.E., 2014. Analysis and modeling of gully headcut dynamics, north American high plains. J. Geophys. Res. Earth Surf. 119 (5), 983-1003.

Rey, F., 2003. Influence of vegetation distribution on sediment yield in forested marly gullies. Catena 50 (2-4), 549-562.

Rey, F., 2009. A strategy for fine sediment retention with bioengineering works in eroded marly catchments in a mountainous Mediterranean climate (Southern Alps, France). Land Degrad. Dev. 20 (2), 210-216.

Rey, F., Burylo, M., 2014. Can bioengineering structures made of willow cuttings trap sediment in eroded marly gullies in a Mediterranean mountainous climate? Geomorphology 204, 564-572.

Rey, F., Isselin-Nondedeu, F., Bédécarrats, A., 2007. Vegetation dynamics on sediment deposits upstream of bioengineering works in mountainous marly gullies in a Mediterranean climate (Southern Alps, France). In: Eco-and Ground BioEngineering: The Use of Vegetation to Improve Slope Stability. Springer, Dordrecht, pp. 297-307.

Rey, F., Bifulco, C., Bischetti, G.B., Bourrier, F., De Cesare, G., Florineth, F., Peklo, K., 2019. Soil and water bioengineering: practice and research needs for reconciling natural hazard control and ecological restoration. Sci. Total Environ. 648, 1210-1218.

Rhemtulla, J.M., Mladenoff, D.J., Clayton, M.K., 2009. Legacies of historical land use on regional forest composition and structure in Wisconsin, USA (mid1800s-1930s-2000s). Ecol. Appl. 19 (4), 1061-1078.

Ribeiro, E., Batjes, N.H., Leenaars, J.G., van Oostrum, A., de Jesus, J.M., 2015. Towards the Standardization and Harmonization of World Soil Data: Procedures Manual ISRIC World Soil Information Service (WoSIS version 2.0). ISRIC World Soil Information.

Rieke-Zapp, D., Poesen, J., Nearing, M., 2007. Effects of rock fragments incorporated in the soil matrix on concentrated flow hydraulics and erosion. Earth Surf. Process. Landf. 32, 1063-1076. https://doi.org/10.1002/esp.1469.

Rienecker, M.M., Suarez, M.J., Gelaro, R., Todling, R., Bacmeister, J., Liu, E., Bloom, S., 2011. MERRA: NASA's modern-era retrospective analysis for research and applications. J. Clim. 24 (14), 3624-3648.

Rienks, S.M., Botha, G.A., Hughes, J.C., 2000. Some physical and chemical properties of sediments exposed in a gully (donga) in northern KwaZulu-Natal, South Africa and their relationship to the erodibility of the colluvial layers. Catena 39 (1), 11-31.

Ries, J.B., Marzolff, I., 2003. Monitoring of gully erosion in the Central Ebro Basin by large-scale aerial photography taken from a remotely controlled blimp. Catena 50 (2-4), 309-328.

Ristić, R., Kašanin-Grubin, M., Radić, B., Nikić, Z., Vasiljević, N., 2012. Land degradation at the Stara Planina ski resort. Environ. Manag. 49 (3), 580-592.

Rodzik, J., Furtak, T., Zglobicki, W., 2009. The impact of snowmelt and heavy rainfall runoff on erosion rates in a gully system, Lublin Upland, Poland. Earth Surf. Proc. Landf. J. Br. Geomorphol. Res. Group 34 (14), 1938-1950.

Roebeling, R.A., Deneke, H.M., Feijt, A.J., 2008. Validation of cloud liquid water path retrievals from SEVIRI using one year of CloudNET observations. J. Appl. Meteorol. Climatol. 47 (1), 206-222.

Romero-Díaz, A., Pereira, E.D., de Vente, J., 2019. Ecosystem services provision by gully control. A review. Cuadern. Investig. Geogr. Geograph. Res. Lett. 45, 333-366.

Rossi, M., 2014. Modeling of Landslide Phenomena and Erosion Processes Triggered by Meteo-Climatic Factors. PhD Thesis. Università degli Studi di Perugia. https://doi. org $/ 10.13140 / 2.1 .3835 .0404$.

Rossi, M., Torri, D., Santi, E., 2015a. Bias in topographic thresholds for gully heads. Nat. Hazards 79 (1), 51-69.

Rossi, M., Torri, D., Santi, E., Bacaro, G., Marchesini, I., Mondini, A.C., Felicioni, G., 2015b. Slope dynamics and climatic change through indirect interactions. In: Engineering Geology for Society and Territory-Volume 1. Springer, Cham, pp. $551-555$. 
Rothwell, J.J., Evans, M.G., Liddaman, L.C., Allott, T.E.H., 2007. The role of wildfire and gully erosion in particulate $\mathrm{Pb}$ export from contaminated peatland catchments in the southern Pennines, UK. Geomorphology 88 (3-4), 276-284.

Roy, D.P., Ju, J., Kline, K., Scaramuzza, P.L., Kovalskyy, V., Hansen, M., Zhang, C., 2010 Web-enabled Landsat Data (WELD): Landsat ETM + composited mosaics of the conterminous United States. Remote Sens. Environ. 114 (1), 35-49.

Rudolf, B., Becker, A., Schneider, U., Meyer-Christoffer, A., Ziese, M., 2009. The new "GPCC full data reanalysis version 5" providing highquality gridded monthly precipitation data for the global land-surface is public available since December 2010. In: GPCC Status Report, December 2010, pp. 1-7.

Rysin, I., Grigoriev, I., Zaytseva, M., Golosov, V., Sharifullin, A., 2017a. Long-term monitoring of gully erosion in Udmurt Republic, Russia. Proc. Int. Assoc. Hydrol. Sci. $375,1$.

Rysin, I.I., 1998. Ovrazhnaja erozija (Gully erosion), Moscow, Iz-sto MSU, 168 p. (in Russian).

Rysin, I.I., Golosov, V.N., Grigoryev, I.I., Zaitceva, M.Y., 2017b. Influence of climate change on the rates of gully growth in the Vyatka-Kama watershed. Geomorphol. RAS 1, 90-103 (in Russian).

Rysin, I.I., Golosov, V.N., Grigoryev, I.I., Zaitceva, M.Y., 2018. On the causes in the contemporary decline in the gully head retreat rates in Udmurtia. Geomorphol. RAS 2018 (1), 75-87 (in Russian).

Sabir, M., El-Khoury, D.L., Salman, M., 2020. Field Guide for Hill Land Reclamation and Water Management. FAO, Beirut. https://doi.org/10.4060/ca8381en.

Saha, S., Moorthi, S., Pan, H.L., Wu, X., Wang, J., Nadiga, S., Liu, H., 2010. The NCEP climate forecast system reanalysis. Bull. Am. Meteorol. Soc. 91 (8), 1015-1058.

Sanchis, M.S., Torri, D., Borselli, L., Poesen, J., 2008. Climate effects on soil erodibility. Earth Surf. Proc. Landf. J. Br. Geomorphol. Res. Group 33 (7), 1082-1097.

Sass, O., Haas, F., Schimmer, C., Heel, M., Bremer, M., Stöger, F., Wetzel, K.F., 2012 Impact of forest fires on geomorphic processes in the Tyrolean Limestone Alps. Geogr. Ann. Ser. A Phys. Geogr. 94 (1), 117-133.

Sauvageot, H., 1994. Rainfall measurement by radar: a review. Atmos. Res. 35 (1), $27-54$.

Saxton, N.E., Olley, J.M., Smith, S., Ward, D.P., Rose, C.W., 2012. Gully erosion in subtropical south-East Queensland, Australia. Geomorphology 173, 80-87.

Schamm, K., Ziese, M., Becker, A., Finger, P., Meyer-Christoffer, A., Schneider, U. Stender, P., 2014. Global gridded precipitation over land: a description of the new GPCC first Guess Daily product. Earth Syst. Sci. Data 6 (1), 49-60.

Schmidt, R., Heinrich, J., 2011. 200 years of land-use change and gully erosion: a case study from Małopolska, SE Poland. Landform Analys. 17, 167-171.

Schmidtchen, G., Bork, H.R., 2003. Changing human impact during the period of agriculture in central Europe: the case study Biesdorfer Kehlen, Brandenburg, Germany. In: Long Term Hillslope and Fluvial System Modelling. Springer, Berlin, Heidelberg, pp. 183-200.

Schmitt, A., Rodzik, J., Zgłobicki, W., Russok, C., Dotterweich, M., Bork, H.R., 2006. Time and scale of gully erosion in the Jedliczny Dol gully system, south-East Poland. Catena 68 (2-3), 124-132.

Schneider, U., Becker, A., Finger, P., Meyer-Christoffer, A., Ziese, M., Rudolf, B., 2014. GPCC's new land surface precipitation climatology based on quality-controlled in situ data and its role in quantifying the global water cycle. Theor. Appl. Climatol. 115 (1-2), 15-40.

Scholes, R., Montanarella, L., Brainich, A., Barger, N., Ten Brink, B., Cantele, M., Kohler, F., 2018. Summary for Policymakers of the Thematic Assessment Report on Land Degradation and Restoration of the Intergovernmental Science-Policy Platform on Biodiversity and Ecosystem Services. IPBES Secretariat, Bonn, Germany, pp. 1-31.

Schotmans, J., Poesen, J., Vanmaercke, M., 2015. Hoe Zijn Ravijnen in Oude Bossen Ontstaan? Studiegeval Neigembos. Driemaandelijks Tijdschrift van de Verenigin Leraars Aardrijkskunde, De Aardrijkskunde, pp. 101-110.

Seginer, I., 1966. Gully development and sediment yield. J. Hydrol. 4, 236-253.

Selkimäki, M., González-Olabarria, J.R., 2017. Assessing gully erosion occurrence in forest lands in Catalonia (Spain). Land Degrad. Dev. 28 (2), 616-627.

Semmel, A., 1995. Development of gullies under forest cover in the Taunus and Crystalline Odenwald Mountains, Germany. Z. Geomorphol. Suppl. 100, 115-127.

Sexton, J.O., Song, X.P., Feng, M., Noojipady, P., Anand, A., Huang, C., Townshend, J.R. 2013. Global, 30-m resolution continuous fields of tree cover: Landsat-based rescaling of MODIS vegetation continuous fields with lidar-based estimates of error Int. J. Digit. Earth 6 (5), 427-448.

Shahabi, H., Jarihani, B., Tavakkoli Piralilou, S., Chittleborough, D., Avand, M., Ghorbanzadeh, O., 2019. A semi-automated object-based gully networks detection using different machine learning models: a case study of Bowen catchment, Queensland, Australia. Sensors 19 (22), 4893.

Sharifullin, A.G., Gafurov, A.M., Golosov, V.N., Dvinskih, A.P., Medvedeva, R.A., 2020 The dynamics of contemporary gully erosion on arable land in the Western Pre-Kama region of the Republic of Tatarstan. Geogr. Nat. Resour. 3, 55-63. https://doi.org/ 10.21782/GiPR0206-1619-2020-3(55-63).

Shellberg, J.G., Spencer, J., Brooks, A.P., Pietsch, T.J., 2016. Degradation of the Mitchell River fluvial megafan by alluvial gully erosion increased by post-European land use change, Queensland, Australia. Geomorphology 266, 105-120.

Shruthi, R.B., Kerle, N., Jetten, V., 2011. Object-based gully feature extraction using high spatial resolution imagery. Geomorphology 134 (3-4), 260-268.

Shruthi, R.B., Kerle, N., Jetten, V., Stein, A., 2014. Object-based gully system prediction from medium resolution imagery using Random Forests. Geomorphology 216, 283-294.

Sidle, R.C., Jarihani, B., Kaka, S.I., Koci, J., Al-Shaibani, A., 2019. Hydrogeomorphic processes affecting dryland gully erosion: Implications for modelling. Progr. Phys. Geogr. Earth Environ. 43 (1), 46-64.
Sidorchuk, A., 1999. Dynamic and static models of gully erosion. Catena 37 (3-4), 401-414.

Sidorchuk, A., 2006. Stages in gully evolution and self-organized criticality. Earth Surf. Proc. Landf. J. Br. Geomorphol. Res. Group 31 (11), 1329-1344.

Sidorchuk, A., Maerker, M., Moretti, S., Rodolfi, G., 2001. Soil erosion modelling in the Mbuluzi River catchment (Swaziland, South Africa). Part I: modelling the dynamic evolution of gullies. Geogr. Fis. Din. Quat. 24, 177-187.

Sidorchuk, A., Maerker, M., Moretti, S., Rodolfi, G., 2003. Gully erosion modelling and landscape response in the Mbuluzi River catchment of Swaziland. Catena 50 (2-4), 507-525.

Šilhán, K., Ružek, I., Burian, L., 2016. Dynamics of gully side erosion: a case study using tree roots exposure data. Open Geosci. 8 (1), 108-116.

Smets, B., Jacobs, T., Swinnen, E., Toté, C., Claes, P., 2016. Product User Manual: Cgls Collection 300m Ndvi Version 1, p. 29.

Smets, B., Verger, A., Camacho, F., Van der Goten, R., Jacobs, T., 2017. Product User Manual: Cgls Collection 1km Lai, Fapar, Fcover Version 2, p. 54.

Smets, B., Jacobs, T., Verger, A., 2018. Product User Manual: Cgls Collection 300m Lai, Fapar, Fcover Version 1, p. 41.

Smolska, E., 2007. Development of gullies and sediment fans in last-glacial areas on the example of the Suwałki Lakeland (NE Poland). Catena 71 (1), 122-131.

Sønstegaard, E., Mangerud, J., 1977. Stratigraphy and dating of holocene gully sediments in Os, western Norway. Norsk Geol. Tidskr. 57, 313-346.

Sorooshian, S., Hsu, K.L., Gao, X., Gupta, H.V., Imam, B., Braithwaite, D., 2000. Evaluation of PERSIANN system satellite-based estimates of tropical rainfall. Bull. Am. Meteorol. Soc. 81 (9), 2035-2046.

Souchere, V., Cerdan, O., Ludwig, B., Le Bissonnais, Y., Couturier, A., Papy, F., 2003. Modelling ephemeral gully erosion in small cultivated catchments. Catena 50 (2-4), 489-505.

Stankoviansky, M., 2003a. Historical evolution of permanent gullies in the Myjava Hill Land, Slovakia. Catena 51 (3-4), 223-239.

Stankoviansky, M., 2003b. Gully evolution in the Myjava Hill Land in the second half of the last millennium in the context of the central-European area. Geogr. Pol. 76 (2), 89-107.

Stankoviansky, M., 2003c. Historical and present Slope Evolution in Hilly Farmland (on the example of the Myjava Hill Land, Slovakia). In: Supplementi di Geografia Fisica aa Dinamica Quaternaria, Suppl 6, pp. 91-97.

Stankoviansky, M., 2005. Geomorphic response to land use changes in the Myjava Hill Land, Slovakia, within the last fifty years. Stud. Geomorphol. Carpatho Balcanica 39, $5-22$.

Stankoviansky, M., Ondrčka, J., 2011. Current and historical gully erosion and accompanying muddy floods in Slovakia. Landform Analys. 17, 199-204.

Steegen, A., Govers, G., Nachtergaele, J., Takken, I., Beuselinck, L., Poesen, J., 2000. Sediment export by water from an agricultural catchment in the Loam Belt of Central Belgium. Geomorphology 33 (1-2), 25-36.

Stöcker, C., Eltner, A., Karrasch, P., 2015. Measuring gullies by synergetic application of $\mathrm{UAV}$ and close range photogrammetry - a case study from Andalusia, Spain. Catena $132,1-11$.

Stocking, M.A., 1980. Examination of factors controlling gully growth. In: De Boodt, M., Gabriels, D. (Eds.), Assessment of Erosion. John Wiley \& Sons, Chichester, pp. 505-520.

Stocking, M.A., 1981. Causes and prediction of the advance of gullies. In: Proceedings of the South-East Asian Regional Symposium on 'Problems of Soil Erosion and Sedimentation', Bangkok, Thailand, 27-29 January 1981, pp. 37-47.

Stokes, A., Douglas, G.B., Fourcaud, T., Giadrossich, F., Gillies, C., Hubble, T., Mickovski, S.B., 2014. Ecological mitigation of hillslope instability: ten key issues facing researchers and practitioners. Plant Soil 377 (1-2), 1-23.

Stolz, C., 2011. Spatiotemporal budgetting of soil erosion in the abandoned fields Area of the " Rahnstätter Hof" near Michelbach (Taunus Mts., Western Germany). Erdkunde 355-370.

Stolz, C., Grunert, J., 2006. Holocene colluvia, medieval gully formation and historical land use. A case study from the Taunus Mountains/southern Rhenish Slate Massif (with 12 figures and 2 tables). Z. Geomorphol. Suppl. 142, 175.

Strunk, H., 2003. Soil degradation and overland flow as causes of gully erosion on mountain pastures and in forests. Catena 50 (2-4), 185-198.

Sun, P., Wu, Y., Yang, Z., Sivakumar, B., Qiu, L., Liu, S., Cai, Y., 2019. Can the grain-forgreen program really ensure a low sediment load on the Chinese Loess Plateau? Engineering 5 (5), 855-864.

Sun, Q., Miao, C., Duan, Q., Ashouri, H., Sorooshian, S., Hsu, K.L., 2018. A review of global precipitation data sets: data sources, estimation, and intercomparisons. Rev. Geophys. 56 (1), 79-107.

Superson, J., Rodzik, J., Reder, J., 2014. Natural and human influence on loess gully catchment evolution: a case study from Lublin Upland, E Poland. Geomorphology 212, 28-40.

Syvitski, J.P., Milliman, J.D., 2007. Geology, geography, and humans battle for dominance over the delivery of fluvial sediment to the coastal ocean. J. Geol. 115 (1), 1-19.

Taborelli, P., Chalumeau, L., Pierre, G., Devos, A., Lenoir, J., Fronteau, G., Bollot, N., 2016. Caractérisation et origine des "creuses": approche sous SIG (exemples en Thiérache), Physio-Géo. Géogr. Phys. Environ. 10, 135-151.

Tachikawa, T., Hato, M., Kaku, M., Iwasaki, A., 2011. Characteristics of ASTER GDEM version 2. In: 2011 IEEE International Geoscience and Remote Sensing Symposium.

Tadono, T., Ishida, H., Oda, F., Naito, S., Minakawa, K., Iwamoto, H., 2014. Precise global DEM generation by ALOS PRISM. ISPRS Annals of the Photogrammetry. Rem. Sens. Spat. Inform. Sci. 2 (4), 71. 
Taguas, E.V., Yuan, Y., Bingner, R.L., Gomez, J.A., 2012. Modeling the contribution of ephemeral gully erosion under different soil managements: a case study in an olive orchard microcatchment using the AnnAGNPS model. Catena 98, 1-16.

Takaku, J., Tadono, T., Tsutsui, K., 2014. Generation of high resolution global dsm from alos prism. ISPRS Ann. Photogram. Rem. Sens. Spat. Inform. Sci. 2 (4).

Takken, I., Beuselinck, L., Nachtergaele, J., Govers, G., Poesen, J., Degraer, G., 1999. Spatial evaluation of a physically-based distributed erosion model (LISEM). Catena 37 (3-4), 431-447.

Taylor, R.J., Massey, C., Fuller, I.C., Marden, M., Archibald, G., Ries, W., 2018. Quantifying sediment connectivity in an actively eroding gully complex, Waipaoa catchment, New Zealand. Geomorphology 307, 24-37.

Tebebu, T.Y., Abiy, A.Z., Zegeye, A.D., Dahlke, H.E., Easton, Z.M., Tilahun, S.A., Steenhuis, T.S., 2010. Surface and subsurface flow effect on permanent gully formation and upland erosion near Lake Tana in the northern highlands of Ethiopia. Hydrol. Earth Syst. Sci. 14 (11), 2207-2217.

Teisseyre, A.K., 1992. Epizodyczne koryta a rozwój suchych dolin w krajobrazie rolniczym. Prace Geol. Mineral. 31, 1-67.

Tekwa, I.J., Laflen, J.M., Kundiri, A.M., 2015. Efficiency test of adapted EGEM model in predicting ephemeral gully erosion around Mubi, Northeast Nigeria. Int. Soil Water Conserv. Res. 3 (1), 15-27.

Thematic Strategy (COM 2006.231), 2006. European Commission: Communication from the Commission to the Council, the European Parliament, the European Economic and Social Committee and the Committee of Regions. In Thematic strategy for soil protection (COM 2006.231). Commission of the European Communities, Brussels.

Thommeret, N., Bailly, J.S., Puech, C., 2010. Extraction of thalweg networks from DTMs: application to badlands. Hydrol. Earth Syst. Sci. 14, 1527-1536.

Thompson, J.R., 1964. Quantitative effect of watershed variables on rate of gully-head advancement. Trans. ASAE 7 (1), 54-0055.

Tichavský, R., Kluzová, O., Břežný, M., Ondráčková, L., Krpec, P., Tolasz, R., Šilhán, K., 2018. Increased gully activity induced by short-term human interventions-dendrogeomorphic research based on exposed tree roots. Appl. Geogr. 98, 66-77.

Torri, D., Poesen, J., 2014. A review of topographic threshold conditions for gully head development in different environments. Earth Sci. Rev. 130, 73-85.

Torri, D., Poesen, J., Borselli, L., 1997. Predictability and uncertainty of the soil erodibility factor using a global dataset. Catena 31 (1-2), 1-22.

Torri, D., Santi, E., Marignani, M., Rossi, M., Borselli, L., Maccherini, S., 2013. The recurring cycles of biancana badlands: erosion, vegetation and human impact. Catena 106, 22-30.

Torri, D., Rossi, M., Brogi, F., Marignani, M., Bacaro, G., Santi, E., Maccherini, S., 2018a. Badlands and the dynamics of human history, land use, and vegetation through centuries. In: Badlands Dynamics in a Context of Global Change. Elsevier, pp. 111-153.

Torri, D., Poesen, J., Rossi, M., Amici, V., Spennacchi, D., Cremer, C., 2018b. Gully head modelling: a Mediterranean badland case study. Earth Surf. Process. Landf. 43 (12), 2547-2561.

Tsendbazar, N.E., De Bruin, S., Herold, M., 2015. Assessing global land cover reference datasets for different user communities. ISPRS J. Photogramm. Remote Sens. 103, 93-114.

Tsvetkova, N.M., Saranenko, I.I., Dubina, A.O., 2015. Application of geographic information systems in evaluating the development of gully erosion in the steppe zone of Ukraine. Biosyst. Div. 23 (2).

Tucker, G., Lancaster, S., Gasparini, N., Bras, R., 2001. The channel-hillslope integrated landscape development model (CHILD). In: Landscape Erosion and Evolution Modeling. Springer, Boston, MA, pp. 349-388.

UNCCD, 2018. United Nations Convention to Combat Desertification.

Uppala, S.M., Kållberg, P.W., Simmons, A.J., Andrae, U., Bechtold, V.D.C., Fiorino, M., Li, X., 2005. The ERA-40 re-analysis. Quart. J. R. Meteorol. Soc. J. Atmosph. Sci. Appl. Meteorol. Phys. Oceanogr. 131 (612), 2961-3012.

US Soil Conservation Service, 1966. Procedures for determining rates of land damage, land depreciation and volume of sediment produced by gully erosion. In: Techn. Release, 32. USDA, Washington, DC, p. 18.

USDA, 2007. Gullies and their Control, Technical Supplement. https://directives.sc.egov. usda.gov/OpenNonWebContent.aspx? content=17826.wba. Accessed 1 Feb 2019.

Ushio, T., Sasashige, K., Kubota, T., Shige, S., Okamoto, K.I., Aonashi, K., Oki, R., 2009. A Kalman filter approach to the Global Satellite Mapping of Precipitation (GSMaP) from combined passive microwave and infrared radiometric data. J. Meteorol. Soc. Japan. Ser. II 87, 137-151.

Valcárcel, M., Taboada, M.T., Paz, A., Dafonte, J., 2003. Ephemeral gully erosion in northwestern Spain. Catena 50 (2-4), 199-216.

Valentin, C., Poesen, J., Li, Y., 2005. Gully erosion: impacts, factors and control. Catena 63 (2-3), 132-153.

Van Rompaey, A.J., Verstraeten, G., Van Oost, K., Govers, G., Poesen, J., 2001. Modelling mean annual sediment yield using a distributed approach. Earth Surf. Process. Landf. 26 (11), 1221-1236.

Van Rompaey, A.J., Govers, G., Puttemans, C., 2002. Modelling land use changes and their impact on soil erosion and sediment supply to rivers. Earth Surf. Process. Landf. 27 (5), 481-494.

Vandaele, K., Poesen, J., 1995. Spatial and temporal patterns of soil erosion rates in an agricultural catchment, Central Belgium. Catena 25 (1-4), 213-226.

Vandaele, K., Poesen, J., Govers, G., van Wesemael, B., 1996. Geomorphic threshold conditions for ephemeral gully incision. Geomorphology 16 (2), 161-173.

Vandaele, K., Poesen, J., Marques de Silva, J.R., Govers, G., Desmet, P., 1997. Assessment of factors controlling ephemeral gully erosion in southern Portugal and Central Belgium using aerial photographs. Z. Geomorphol. 41 (3), 273-288.
Vandekerckhove, L., Poesen, J., Wijdenes, D.O., De Figueiredo, T., 1998. Topographical thresholds for ephemeral gully initiation in intensively cultivated areas of the Mediterranean. Catena 33 (3-4), 271-292.

Vandekerckhove, L., Poesen, J., Wijdenes, D.O., Gyssels, G., Beuselinck, L., De Luna, E., 2000a. Characteristics and controlling factors of bank gullies in two semi-arid Mediterranean environments. Geomorphology 33 (1-2), 37-58.

Vandekerckhove, L., Poesen, J., Oostwoud Wijdenes, D., Nachtergaele, J., Kosmas, C., Roxo, M.J., De Figueiredo, T., 2000b. Thresholds for gully initiation and sedimentation in Mediterranean Europe. Earth Surf. Process. Landf. 25 (11), 1201-1220.

Vandekerckhove, L., Muys, B., Poesen, J., De Weerdt, B., Coppé, N., 2001a. A method for dendrochronological assessment of medium-term gully erosion rates. Catena 45 (2), $123-161$.

Vandekerckhove, L., Poesen, J., Wijdenes, D.O., Gyssels, G., 2001b. Short-term bank gully retreat rates in Mediterranean environments. Catena 44 (2), 133-161.

Vandekerckhove, L., Poesen, J., Govers, G., 2003. Medium-term gully headcut retreat rates in Southeast Spain determined from aerial photographs and ground measurements. Catena 50 (2-4), 329-352.

Vanmaercke, M., Poesen, J., Broeckx, J., Nyssen, J., 2014. Sediment yield in Africa. Earth-Sci. Rev. 136, 350-368.

Vanmaercke, M., Poesen, J., Maetens, W., de Vente, J., Verstraeten, G., 2011. Sediment yield as a desertification risk indicator. Sci. Total Environ. 409 (9), 1715-1725.

Vanmaercke, M., Maetens, W., Poesen, J., Jankauskas, B., Jankauskiene, G., Verstraeten, G., de Vente, J., 2012. A comparison of measured catchment sediment yields with measured and predicted hillslope erosion rates in Europe. J. Soils Sediments 12 (4), 586-602.

Vanmaercke, M., Poesen, J., Van Mele, B., Demuzere, M., Bruynseels, A., Golosov, V., Fuseina, Y., 2016. How fast do gully headcuts retreat? Earth Sci. Rev. 154, 336-355.

Vanmaercke, M., Chen, Y., Haregeweyn, N., De Geeter, S., Campforts, B.,

Heyndrickx, W., Poesen, J., 2020. Predicting gully densities at sub-continental scales: a case study for the Horn of Africa. Earth Surf. Process. Landf. 45 (15), 3763-3779.

Vannoppen, W., Vanmaercke, M., De Baets, S., Poesen, J., 2015. A review of the mechanical effects of plant roots on concentrated flow erosion rates. Earth Sci. Rev. 150, 666-678.

Vanwalleghem, T., Van Den Eeckhaut, M., Poesen, J., Deckers, J., Nachtergaele, J., Van Oost, K., Slenters, C., 2003. Characteristics and controlling factors of old gullies under forest in a temperate humid climate: a case study from the Meerdaal Forest (Central Belgium). Geomorphology 56 (1-2), 15-29.

Vanwalleghem, T., Poesen, J., Nachtergaele, J., Verstraeten, G., 2005a. Characteristics, controlling factors and importance of deep gullies under cropland on loess-derived soils. Geomorphology 69 (1-4), 76-91.

Vanwalleghem, T., Poesen, J., Van Den Eeckhaut, M., Nachtergaele, J., Deckers, J., 2005b. Reconstructing rainfall and land-use conditions leading to the development of old gullies. The Holocene 15 (3), 378-386.

Vanwalleghem, T., Bork, H.R., Poesen, J., Schmidtchen, G., Dotterweich, M., Nachtergaele, J., De Bie, M., 2005c. Rapid development and infilling of a buried gully under cropland, Central Belgium. Catena 63 (2-3), 221-243.

Vanwalleghem, T., Bork, H.R., Poesen, J., Dotterweich, M., Schmidtchen, G., Deckers, J., Martens, M., 2006. Prehistoric and Roman gullying in the European oess belt: a case study from Central Belgium. The Holocene 16 (3), 393-401.

Vanwalleghem, T., Van Den Eeckhaut, M., Poesen, J., Govers, G., Deckers, J., 2008. Spatial analysis of factors controlling the presence of closed depressions and gullies under forest: application of rare event logistic regression. Geomorphology 95, 504-517.

Vergari, F., Della Seta, M., Del Monte, M., Fredi, P., Lupia Palmieri, E., 2013a. Long- and short-term evolution of several Mediterranean denudation hot spots: the role of rainfall variations and human impact. Geomorphology 183, 14-27.

Vergari, F., Della Seta, M., Del Monte, M., Barbieri, M., 2013b. Badlands denudation "hot spots": the role of parent material properties on geomorphic processes in 20-years monitored sites of Southern Tuscany (Italy). Catena 106, 31-41.

Verstraeten, G., Poesen, J., 1999. The nature of small-scale flooding, muddy floods and retention pond sedimentation in Central Belgium. Geomorphology 29 (3-4), 275-292.

Verstraeten, G., Prosser, I.P., Fogarty, P., 2007. Predicting the spatial patterns of hillslope sediment delivery to river channels in the Murrumbidgee catchment, Australia. J. Hydrol. 334 (3-4), 440-454.

Vieira, A., Gonçalves, A.B., Lourenço, L., Nunes, A., Castro, A.M., Leite, F.F., 2014. Soil Erosion after Forest Fires: Evaluation of Mitigation Measures Applied to Drainage Channels in the Northwest of Portugal.

Vieira, D.A., Dabney, S.M., Yoder, D.C., 2015. Distributed soil loss estimation system including ephemeral gully development and tillage erosion. Proc. Int. Assoc. Hydrol. Sci. 367,80 .

Vigiak, O., Borselli, L., Newham, L.T.H., McInnes, J., Roberts, A.M., 2012. Comparison of conceptual landscape metrics to define hillslope-scale sediment delivery ratio. Geomorphology 138, 74-88.

Vigiak, O., Malagó, A., Bouraoui, F., Vanmaercke, M., Obreja, F., Poesen, J., Grošelj, S., 2017. Modelling sediment fluxes in the Danube River Basin with SWAT. Sci. Total Environ. 599, 992-1012.

Walker, S.J., Wilkinson, S.N., van Dijk, A.I., Hairsine, P.B., 2020. A multi-resolution method to map and identify locations of future gully and channel incision. Geomorphology 107115.

Wang, Z.J., Jiao, J.Y., Rayburg, S., Wang, Q.L., Su, Y., 2016. Soil erosion resistance of "grain for Green" vegetation types under extreme rainfall conditions on the Loess Plateau, China. Catena 141, 109-116. 
Watson, A., Evans, R., 1991. A comparison of estimates of soil erosion made in the field and from photographs. Soil Tillage Res. 19 (1), 17-27.

Watson, A., Evans, R., 2007. Water erosion of arable fields in North-East Scotland, 1985-2007. Scott. Geogr. J. 123 (2), 107-121.

Wexler, R., Atlas, D., 1963. Radar reflectivity and attenuation of rain. J. Appl. Meteorol. Climatol. 2 (2), 276-280.

WFD, Directive 2000/60/EC, 2020. European Commission, Water Framework Directive (WFD). URL: https://eur-lex.europa.eu/legal-content/EN/TXT/?uri=CELEX:3 2000 L0060.

Whitford, J.A., Newham, L.T.H., Vigiak, O., Melland, A.R., Roberts, A.M., 2010. Rapid assessment of gully sidewall erosion rates in data-poor catchments: a case study in Australia. Geomorphology 118 (3-4), 330-338.

Wilkinson, S.N., Prosser, I.P., Rustomji, P., Read, A.M., 2009. Modelling and testing spatially distributed sediment budgets to relate erosion processes to sediment yields. Environ. Model. Softw. 24 (4), 489-501.

Wilkinson, S.N., Dougall, C., Kinsey-Henderson, A.E., Searle, R., Ellis, R., Bartley, B., 2014. Development of a time-stepping sediment budget model for assessing land use impacts in large river basins. Sci. Total Environ. 468-469, 1210-1224.

Wilkinson, S.N., Hairsine, P.B., Brooks, A., Bartley, R., Hawdon, A., Pietsch, T., Shepherd, B., Austin, J., 2019. Gully and Stream Bank Toolbox (2nd Edition): A Technical Guide for the Reef Trust Phase IV Gully and Stream Bank Erosion Control Program. CSIRO, Report to the Department of the Environment (Reef Program).

Willgoose, G., 2005. Mathematical modeling of whole landscape evolution. Annu. Rev. Earth Planet. Sci. 33, 443-459.

Willgoose, G., 2018. Principles of Soilscape and Landscape Evolution. Cambridge University Press, p. 334.

Willmott, C.J., Matsuura, K., 1995. Smart interpolation of annually averaged air temperature in the United States. J. Appl. Meteorol. 34 (12), 2577-2586.

Wilson, G.V., Shields, F.D., Bingner, R.L., Reid-Rhoades, P., DiCarlo, D.A., Dabney, S.M., 2008. Conservation practices and gully erosion contributions in the Topashaw Canal watershed. J. Soil Water Conserv. 63 (6), 420-429.

Woodward, D.E., 1999. Method to predict cropland ephemeral gully erosion. Catena 37 (3-4), 393-399.

Xiang-zhou, X., Hong-wu, Z., Ouyang, Z., 2004. Development of check-dam systems in gullies on the Loess Plateau, China. Environ. Sci. Pol. 7 (2), 79-86.

Xie, P., Arkin, P.A., 1997. Global precipitation: a 17-year monthly analysis based on gauge observations, satellite estimates, and numerical model outputs. Bull. Am. Meteorol. Soc. 78 (11), 2539-2558.

Xie, P., Janowiak, J.E., Arkin, P.A., Adler, R., Gruber, A., Ferraro, R., Curtis, S., 2003. GPCP pentad precipitation analyses: an experimental dataset based on gauge observations and satellite estimates. J. Clim. 16 (13), 2197-2214.

Xie, P., Chen, M., Shi, W., 2010. CPC global unified gauge-based analysis of daily precipitation. In: Preprints, 24th Conf. On Hydrology, Atlanta, GA. Amer. Meteor. Soc, p. 2.

Xie, P., Adler, R.F., Huffman, G.J., Bolvin, D., 2011. Global Precipitation Climatology Project-Pentad, Version 2.2. NOAA National Climatic Data Center.

Xu, M., Li, Q., Wilson, G., 2016. Degradation of soil physicochemical quality by ephemeral gully erosion on sloping cropland of the hilly Loess Plateau, China. Soil Tillage Res. 155, 9-18.

Yermolaev, O.P., 2014. Erosion processes of the forest and forest-steppe zones in the eastern part of the Russian Plain. World Appl. Sci. J. 29 (3), 453-459.
Yibeltal, M., Tsunekawa, A., Haregeweyn, N., Adgo, E., Meshesha, D.T., Aklog, D., Ebabu, K., 2019. Analysis of long-term gully dynamics in different agro-ecology settings. Catena 179, 160-174.

Zabihi, M., Mirchooli, F., Motevalli, A., Darvishan, A.K., Pourghasemi, H.R., Zakeri, M. A., Sadighi, F., 2018. Spatial modelling of gully erosion in Mazandaran Province, northern Iran. Catena 161, 1-13.

Zakerinejad, R., Maerker, M., 2014. Prediction of gully erosion susceptibilities using detailed terrain analysis and maximum entropy modeling: a case study in the Mazayjan Plain. Southwest Iran: Geogr. Fisica e Dinamica Quaternaria 37 (1), 67-76.

Zalidis, G.C., Tsiafouli, M.A., Takavakoglou, V., Bilas, G., Misopolinos, N., 2004. Selecting agri-environmental indicators to facilitate monitoring and assessment of EU agri-environmental measures effectiveness. J. Environ. Manag. 70 (4), 315-321.

Zegeye, A.D., Steenhuis, T.S., Blake, R.W., Kidnau, S., Collick, A.S., Dadgari, F., 2010. Assessment of soil erosion processes and farmer perception of land conservation in Debre Mewi watershed near Lake Tana, Ethiopia. Ecohydrol. Hydrobiol. 10 (2-4), 297-306.

Zegeye, A.D., Langendoen, E.J., Steenhuis, T.S., Mekuria, W., Tilahun, S.A., 2020. Bank stability and toe erosion model as a decision tool for gully bank stabilization in sub humid Ethiopian highlands. Ecohydrol. Hydrobiol. 20 (2), 301-311.

Zgłobicki, W., Baran-Zgłobicka, B., 2011. Gullies as an indicator of human impact on loess landscape (Case study: North Western part of Lublin Upland, Poland). Zeitschrift Geomorphol. Suppl. Issues 55 (1), 119-137.

Zgłobicki, W., Rodzik, J., Superson, J., Dotterweich, M., Schmitt, A., 2014. Phases of gully erosion in the Lublin Upland and Roztocze region. Ann. UMCS B 69 (1), 149-162.

Zgłobicki, W., Baran-Zgłobicka, B., Gawrysiak, L., Telecka, M., 2015a. The impact of permanent gullies on present-day land use and agriculture in loess areas (E. Poland). Catena 126, 28-36.

Zgłobicki, W., Kołodyńska-Gawrysiak, R., Gawrysiak, L., 2015b. Gully erosion as a natural hazard: the educational role of geotourism. Nat. Hazards 79 (1), 159-181.

Zgłobicki, W., Poesen, J., Daniels, M., Del Monte, M., Guerra, A.J., Joshi, V., SoléBenet, A., 2018. Geotouristic value of Badlands. In: Badlands Dynamics in a Context of Global Change. Elsevier, pp. 277-313.

Zglobicki, W., Poesen, J., Cohen, M., Del Monte, M., García-Ruiz, J.M., Ionita, I., Pica, A., 2019. The potential of permanent gullies in Europe as geomorphosites. Geoheritage 11 (2), 217-239.

Zhao, J., Vanmaercke, M., Chen, L., Govers, G., 2016. Vegetation cover and topography rather than human disturbance control gully density and sediment production on the Chinese Loess Plateau. Geomorphology 274, 92-105.

Zierholz, C., Prosser, I.P., Fogarty, P.J., Rustomji, P., 2001. In-stream wetlands and their significance for channel filling and the catchment sediment budget, Jugiong Creek, New South Wales. Geomorphology 38 (3-4), 221-235.

Zorina, E.F., 2003. Ovraznaya Erosiya: Zakinimernosti I Potencial Razvitiya (Gully Erosion: Development Patterns and Potential). GEOS, Moscow, p. 170 (in Russian).

Zorn, M., 2009a. Erosion processes in Slovene Istria-part 1: Soil erosion. Acta Geogr. Sloven. 49 (1), 39-87.

Zorn, M., 2009b. Erosion processes in Slovene Istria-part 2: Badlands. Acta Geogr. Sloven. 49 (2), 291-341.

Zucca, C., Canu, A., Della Peruta, R., 2006. Effects of land use and landscape on spatial distribution and morphological features of gullies in an agropastoral area in Sardinia (Italy). Catena 68 (2-3), 87-95. 